\title{
Cell differentiation and adhesion in colorectal cancer
}

Citation for published version (APA):

van der Wurff, A. A. (1998). Cell differentiation and adhesion in colorectal cancer. [Doctoral Thesis, Maastricht University]. Universiteit Maastricht. https://doi.org/10.26481/dis.19980515aw

Document status and date:

Published: 01/01/1998

DOI:

10.26481/dis.19980515aw

Document Version:

Publisher's PDF, also known as Version of record

\section{Please check the document version of this publication:}

- A submitted manuscript is the version of the article upon submission and before peer-review. There can be important differences between the submitted version and the official published version of record.

People interested in the research are advised to contact the author for the final version of the publication, or visit the DOI to the publisher's website.

- The final author version and the galley proof are versions of the publication after peer review.

- The final published version features the final layout of the paper including the volume, issue and page numbers.

Link to publication

\footnotetext{
General rights rights.

- You may freely distribute the URL identifying the publication in the public portal. please follow below link for the End User Agreement:

www.umlib.nl/taverne-license

Take down policy

If you believe that this document breaches copyright please contact us at:

repository@maastrichtuniversity.nl

providing details and we will investigate your claim.
}

Copyright and moral rights for the publications made accessible in the public portal are retained by the authors and/or other copyright owners and it is a condition of accessing publications that users recognise and abide by the legal requirements associated with these

- Users may download and print one copy of any publication from the public portal for the purpose of private study or research.

- You may not further distribute the material or use it for any profit-making activity or commercial gain

If the publication is distributed under the terms of Article $25 \mathrm{fa}$ of the Dutch Copyright Act, indicated by the "Taverne" license above, 
1998 A.A.M. van der Wurf, Maastricht, The Netherlands

All rights reserved. No part of this publication may be reproduced or transmitted in any form or by any means, electronic or mechanical, including photocopy, recording or any informationstorage or retrieval system, without permission in writing from the copyright owner.

ISBN 90115102

Vormgeving en druk: Datawyse I Universitaire Pers Maastricht 


\section{Cell differentiation and adhesion in colorectal cancer}

\section{Proefschrift}

ter verkrijging van de graad van doctor aan de Universiteit Maastricht, op gezag wan de Rector Magnificus, Prof. dr. A. C. Nieuwenhuigzen Kruseman, volgens het besluit van het College van Decanen in het openbaar te verdedigen op vrijdag 15 mei 1998 om 14.00 uur door

\section{A.A.M. van der Wurff}


Prof. dr. J.W. Arends

Prof. dr. F.T. Bosman (Uniwersity of Lausanne, Zw.)

\section{Co-promotor}

Dr. J.ten Kate (De Weverziekenhuis, Healen)

\section{Beoordelingscommissie}

Prof. dr. F.C.S. Ramaekers (voorzitter)

Prof. dr. H.F. Hillen

Prof dr. M. Marcel (Rijksuniversitet Gent, B.)

Prof. dr. M.F. won Meyenfeldt

Prof. dr. D.J. Ruiter (Katholieke Universiteit Nijmegen)

De stichning Kinische Pathologie Zuid-Limburg heef voor de rot stand koming wan dit proefschifif een financiële bijdrage geleverd. 


\section{Contents}

Chapter 1

General introduction 7

1.1 introduction 8

1.2 Invasion and metastasis in colorectal cancer $\quad 10$

1.2.1 Molecular carcinogenesis 10

1.2 .2 Cell achesion molecules 12

1.3 Differentiation 15

1.3.1 Normal colonic epithelium, the different cell lineages 15

1.3 .2 Colonic stem cells 16

1.3.3 Differentiation and maturation of tumour cells. The tumoul stem cell concept $\quad 17$

1.4 Aim of the study 17

\section{Chapter 2}

Colonic crypt isolation and the production of anti-crypt cell antibodies 27

Chapter 3

Expression of a markef for colonic crypt base cells is correlated

with poor prognosis in human colorectal cancer. (Gut 1998; 42:63-70)

Chapter 4

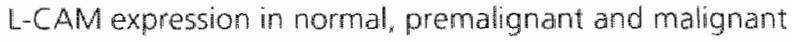

colon mucosa (J Pathal 1992;168:281-286) 55

\section{Chapter 5}

L-CAM expression in lymph node and liver metastases of

colorectal carcinomas (J Pathol 1994;172:177-182) 65

\section{Chapter 6}

Patterns of $\alpha$ - and $\beta$-catenin and E-cadherin expression in colorectal adenomas and carcinomas (J Pathol 1997; 182:325-330) 75 
General discussion

Summany 93

Samenvating 95

Nawoord 97

Curriculum vitae $\quad 99$

List of publications/abstracts and proceedings 101 


\section{General introduction}

\section{Contents Chapter 1}

1.1. Bntroduction

1.2 Anvasion and netastasis in colorectal cancer

1.2. Molecular calcinogenes

12.2 Celladhesion molecules

13 Differentiation

131 Nomal colonic epithelium the different cell lineages

132 colonic stem cells

1,3, Differentiation and maturation of tumour cells the unour stem cell concept

1.4 Aim of the study 


\subsection{Intiroduction}

Colorectal cancer is one of the most common forms of cancer in western commtries. The annual incidence is second only to lung cancer in males and to breas cancer in females." In Europe the annual mortalicy rate reaches 80.000 , in the Netherlands alone 7500 new patients are diagnosed every year'. Like in most solid tumours despite more intense trearment these figures have not substanrially improved ower the past two decades.

Trearment of choice still remains radical surgery with adequate margins of colon and remowal of regional lymph nodes ${ }^{3.5}$. However, even after curative surgical resection, 5-year survival is in the order of 30-50\% . Chemo- and radiotherapy have not dramatically changed survival, although for Dukes $C$ adenocarcinomas adjuvant chemotherapy (Fluorouracil and Levimasole) results in a reducvion of the mortality rate to $33 \%$.

The two most important determinants of prognosis are stage and grade assessed by parhologists. Stage is defined by the process of invasion and metastasis, grade upon the differentiation of the tumour cells.

Tumour stage is based on the Dukes classification "which describes the stage of extension of the adenocarcinomas. In this classification Dukes $A$ is defined as extension of the tumour into the submucosa or muscularis propria and Dukes $B$ as tumour growch through the bowel wall without metastasis. Dukes C rumours in addition show lymph node metastasis, while Dukes $D^{\prime \prime}$ tumours grow into adjacent organs and/or show distant metastasis. Throughout the years, different modifications of the Dukes classification were introduced, such as the AstlerColler staging system ${ }^{2}$ and the TNM classificarion of which a schematic overview is presented in Table I. Staging of tumours only provides prognostic in formation at the population level. It should be realized that at the individual level chances of survival of patients within the same stage may substantially wary. Grading is much less relevant for prognostication than staging, but at the popularion level well "moderately well and poorly differentiated carcinomas divided according to architectural and cytonuclear features "show slighr differences in respective survival. Hiscological grading, however, is subjective and great intraas well as interobserver variations have been reported. Other histological fearures which have been evaluated as prognostic parameters include eosinophiliat ${ }^{4}$ and the extent of the inflammatory infiltrate as a reflection of the host respons to the tumour. Jass er al. " combined tumour growth partern and grade features in his staging system (sec also Table I).

Another way ro assess tumour grade has been co analyse differenciational characteristics of the cumour cell population chrough the expression of markers of differentiation which have been developed for the different cell lineages in the 
Table I.

Dukes

A extension of the tumour up to muscularis prophia

B1 into muscularis propria

Q2 through muscularis propria, but limited to the bowel wall

83 through muscularis propria, throwgh serose

C1 up or nto muscularis propra, without lymph node metastasis

C2 through musculanis propria, with lymph node metastashs

b $\quad$ Into adjacent organs and/or distant metastasis

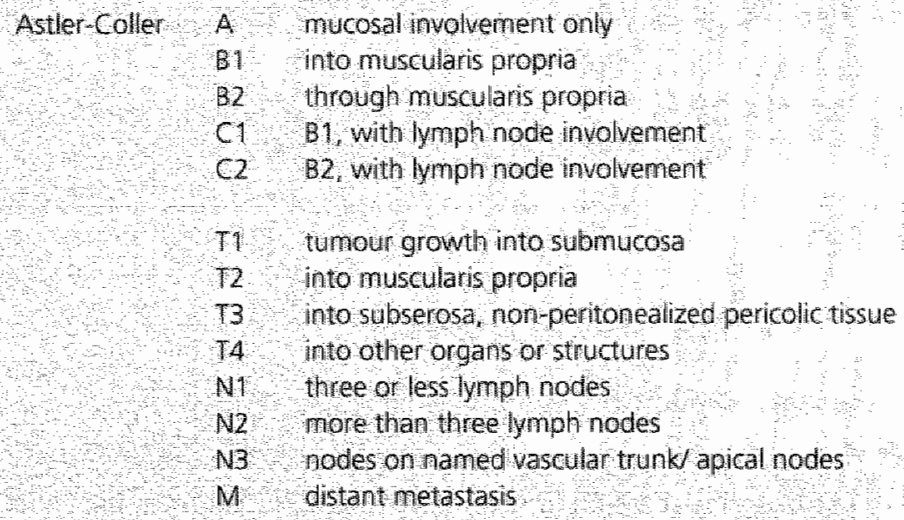

Jass tumour staging

Sconng

Limitation of growth to bowel wall

Yes:

0

No

lovasive margin

Expanding

0

Anfitirating

No. of lymph nodes with metastasis a.

$1-4$

$>4$

\section{0}

1

2

Conspicious peritumoural hmphocytic infittrate

Yes.

No

0

1

Scoring: Group 1, 01 (excellent prognosis); Group 1, 2, Group ll, 3, Group M. $4-5$ (poor prognosis) 
colonic epihelium identifying end stages of differentiation. For these markers a consistent prognostic significance has not been reported", whereas these often appear to be coexpressed in a large proportion of the tumours". An exeption, however, seems to be neuroendocrine differentiation, which was repearedly found to correlare with worse prognosis ${ }^{15,21}$. Other invesrigators, however, reported no prognostic significance for neuroendocrine differentiation ${ }^{22}$.

The disappointing and inconsistent contribution of the available histological parameters to the establishment of prognosis forms the background of this study. We reasoned that in search of makkers for tumour behaviour, in stead of paramerers related to terminal tumour cell differentiation it mighe be more worth while to look for stem cell characreristics since these cells are responsible for tumour growth, invasion and metastasis.

After a brief discussion of the molecular events in colorectal carcinogenesis in this introductory chapter, we will dewelop the stem cell concept in relation to differentiation in colon cancer and also discuss the role of cell adhesion in colorectal cancer metastasis.

\subsection{Invasion and metastasis in colorectal cancer}

The process of metastasis is divided into sequential steps ${ }^{23.24}$. First, the carcinoma cell has to derach from the primary tumour probably by downregularing the expression of specific cell-cell adhesion molecules ${ }^{2 \% 26}$. Secondly, to traverse the epithelial basement membrane, enhanced proteolytic activiry is needed ${ }^{27}$. Also, cell-basement membrane adhesion molecules have to be inacrivated ${ }^{28}$. In order to traverse the extracellular matrix, motility factors should be expressed $^{2 w 3 !}$. Thirdly, the barrier of lymph-or blood vessel wall has to be raken for further dissemination and the carcinoma cells will have to survive in the circulation. The pattern of metastatic spread probably is partly determined by sire specific interactions with organ specific endothelial cell properties and by tissue specific microenvironment. Finally, the invasion process is reversed: traversing of the vessel wall and extracellutar matrix occurs and at the metastaric site again cell-cell adhesion molecules are expressed to reestablish tissue architecture, finally resulting in a merastatic cumour.

\subsubsection{Molecular carcinogenesis}

The paradigm for molecular carcinogenesis of colorectal cancer is the Vogelstein concept. A cascade of molecular events has been proposed in which to some extent the sequence, but more importantly the accumulation of a number of genetic abnormalities determines the final biological behaviour of the tumour ${ }^{32.35}$. 


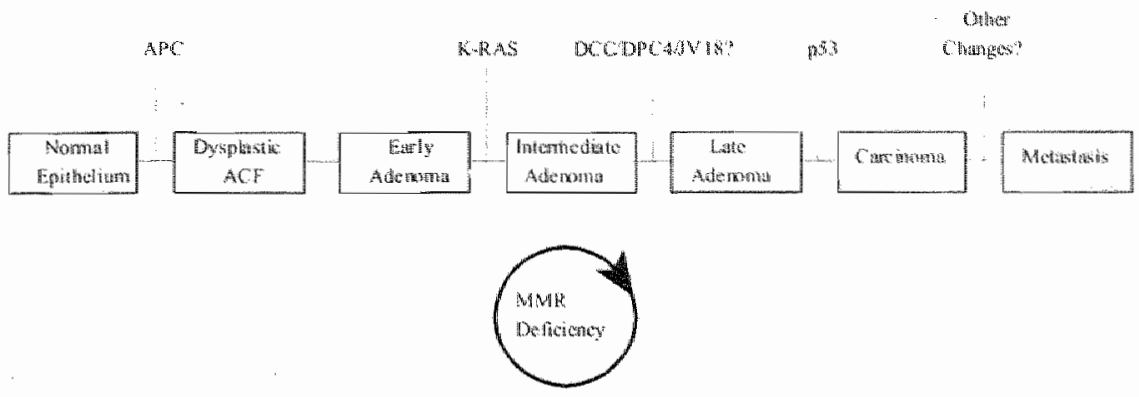

Figure 1. Genes in colorectal carcinogenesis

The different onco(suppressor) genes playing a role in colorectal carcinogenesis are shown schematically in Fig. 1.

It is beyond the scope of this thesis to extensively discuss the individual genes, but $A P C$ and DCC are of interest given the contexr of our investigation.

The APC (Adenomatous Polyposis Coli) tumour suppressor gene locus was discovered by identification of a constitutional deletion of the chromosomal band $5 q 21$ in a patient with familial adenomatous polyposis. ${ }^{36}$. The gene was identified by positional cloning. In colorectal cancers with no known familial predisposition, allelic loss of chromosome $5 q 21$ has been found in $20-50 \%$ of the cases $^{i 3} .5 q$ allelic losses are most frequently detected in small early adenomas from patients without polyposis, which suggests that inactivation of one or both of the alleles by somatic mutation occurs at an early stage of tumour development. APC is considered to be the gate keeper gene in colorectal tumourigenesis. The gene product is a large protein (a 2844 -amino acid polypeptide) with different domains binding to several orher proteins, amongst which $\beta$-catenin, which is involved in cell adhesion through its complexion with $E$-cadherin ${ }^{19,37}$. Recently it has become apparent that $\beta$-catenin also plays a role in the Wnt signaling sequence through $\mathrm{T}$ cell transcription factor $4(\mathrm{Tcf}-4)^{\mathrm{sin}-11}$. APC also colocalizes with the cubuline skeleton and is claimed to be involved in the process of apoprosis ${ }^{53}$.

The DCC (Deleted in Colorectal Cancer) gene was also identified by positional cloning and is located on chromosome $18 \mathrm{q} 21$. Loss of heterozygosity (1OH) at this locus occurs in $70 \%$ of carcinomas and in $50 \%$ of far advanced adenomas, which made this region suspect for localization of a tumour suppressor gene". Also, LOH of $18 \mathrm{q}$ has been correlared with poor prognosis". The DCC gene encodes a protein with homology to neural cell adhesion molecule, NCAM". 
For this reason it is conceivable that the DCC product is involved in invasion, altered adhesion and metastanic potential of rumour cells.

Despite the unraveling of some generic factors associated with colorectal tumourigenesis, the exact mechanisms leading to colon carcinoma, whether genetic or environmental largely remain unknown. Vogelstein ex al. postulate in their model that once carcinomas are formed, the accumulated loss of suppressor genes correlates with the ability of the rumour to metastasize. However, no detailed genetic alterarions have been described in the association of metastasis. For prognosis, however, this process of metastasis largely derermines patient survival.

\section{2 .2 Cell adhesion molecules}

In invasion and metastasis, cell adhesion molecules (CAM) play a pivotal role. Invasive cells must derach from their intercellular connections, which are mediated by CAM, and need to develop a surface molecular structure, including the expression of matrix receptors, which allows them to interact with the exrracellular matrix. (For an overview see Freemont ${ }^{44}$ ).

Acthesion molecules generaily are divided into five families: selecrins, immunoglobuline-like superfamily, integrins, hyaluronate receptors and cadherins (Fig. 2).

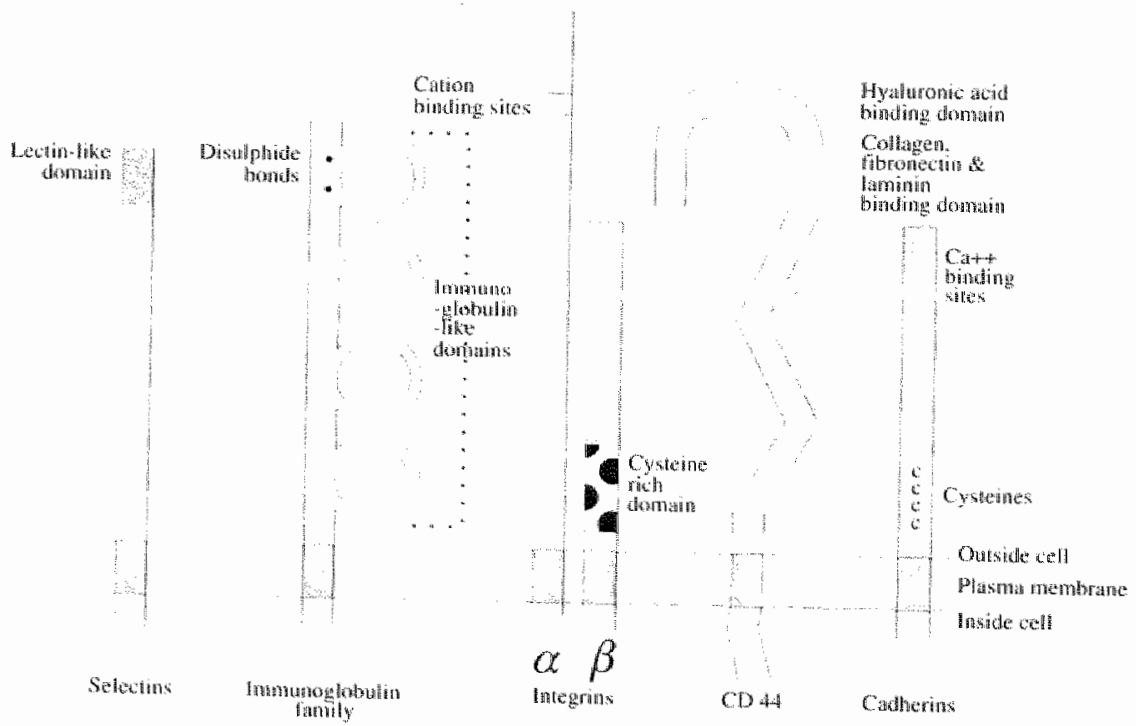

Figure 2 
A Selectins. The selectin molecules possess three different protcin domains; a calcium dependent lectin domain, a repear domain corresponding to that in epidermal growth factor (EGF) and a varying number of repears of a domain of complement regulatory proteins (CRP). There is a high degree of homology bewween the selectins, which is probably the result of duplication of an ancestral gene, followed by exon diversification and duplication. The genes for all selecrin proreins are on chromosome 1.

Selectins play an important role in the inflammatory response by taking part in the earliest phases of leucocyte extravasation. Leucocytes move towards the wall of the capillaries and begin to role along the endorhellium ${ }^{35}$. This process requires interaction between a receptor on endothelial cells-the selectins- and a ligand on the moving leucocytes (on neutrophils, the ligand for the selectins is the sialyl Lewis X determinant).

The selectin family has three members: E-, P-and L-selectin. E-selectin is expressed on endorhelium and mediates neutrophil, monocyre and some T lymphocyre adhesion to the endothelium. E-selectin may play a role in metastasis since it was shown to mediate binding of the colon carcinoma cell line HT-29 to endorhelium ${ }^{47}$. Also, the ability of cell lines to bind to E-selecrin was shown to be direcrly related to their potential to metastase to the liver". L-selectin is expressed on peripheral $T$ and $B$ lymphocytes, neutrophils and bone marrow derived cells. Apart from a role in the process of leucocyte rolling, this selectin also functions as a homing receptor. P-selectin is expressed on thrombocytes and endothelium and mediates adhesion of neutrophils and monocytes to thrombocytes and endothelial cells, thereby causing a histamin release few minutes after thrombin activation. Also, interaction of activated platelets with tumour cells via $P$-selectin may facilitate metastasis through arrest of the formed aggregate in microvessels or by the provision of plateler growth factor to the co-aggregated rumour cells ${ }^{43}$.

B Immunoglobuline-like superfarnily. The Immunoglobulin-like superfamily of adhesion molecules consists of more than seventy members. All members have their molecular structure in common with the immunoglobulin-fold, consisting of two $\beta$ pleared sheets stabilized by disulfide bonds, as basic common motif. Members include molecules concerned with antigen recognition by and adhesion to lymphocytes (CD3,CD4). Another subgroup is formed by the intercellular adhesion molecules (ICAM), which are expressed on epirhelial and endothelial cells. Also included are the neural cell adhesion molecules (NCAM) ${ }^{\text {it }}$. As mentioned before, the DCC gene codes for a protein with homology to NCAM

C Integrins. Integrins are a family of heterodimeric membrane glycoproteins expressed on a diversity of cell types which function in cell-cell adhesion as well as 
cell-substratum adhesion. Their structure is very characteristic and formed of two non-covalently associated subunits, $\alpha$ and $\beta$. Initially the integrins were subdivided into three subfamilies ( $\beta 1$ or Very Late Acrivared VLA proreins, $\beta 2$ or leucams and $\beta 3$ or cytoadhesins), in which a $\beta$ unit was thought to associare with different $\alpha$ units. However this classification has become less rigid since more $\alpha$ than $\beta$ units have been characterized nowadays and individual $\alpha$ units can associate with more than one $\beta$ subunit. The recognition site for some integrins is an RGD sequence (Arginin, Glycin and Aspartic acid) on the extracellular matrix. In vitro, RGD peprides have been shown to inhibir tumour cell migration ${ }^{415 ?}$ ?

D Hyaluronate veceptors. Hyaluronate is a component of the extracellular marrix and plays a role in several pathological processes including inflammation and carcinogenesis. Cells bind to hyaluronate through cell surface proteins, one of which is CD44. Through alternative splicing of its exons, CD44 can display heterogeneity with a variery of physiological roles for the splice variants including cell migration. A specific isoform implicated in merastatic potential is called CD 44v. In colonic cancers, a direct relationship has been described between this isoform and metastatic potential: the isoform CD $44 \mathrm{v} 6$ is expressed in all cases of the most aggressive tumours, whereas in normal colonic epithelium no expression is found ${ }^{3.3}$. In addirion, it has been shown that CD44 variant expression has prognostic significance in colorectal cancer ${ }^{\text {s.t. }}$.

E Cadherins. The Cadherin family is made up by calcium dependent homotypic cell adhesion molecules playing a role in the maintenance of intregrity of multicellular structures. The molecules are also important in embryologic development". They consist of a precursor polypeptide which after a series of posttranslational modifications (glycosylation, phosphorylation and proteolytic cleavagel becomes a mature protein of 723-748 amino acids. In the extracellular domain some repeats contain a calcium binding site. Also a transmembrane and a short cytoplasmic domain with a highly conserved region of homology exist. Until now many different cadherins have been identified amongst which E-(epithelial), $N$-(neural), and P-(placental) cadherins are the best known. The first detected cadherin was called uyomorulin, because it was found to play a role in early mouse development where it mediates the compaction process at the morula stage ${ }^{\text {sit. }}$. E-cadherin is also known as cell-CAM 120/80 and is homologous to L-CAM in the chicken and Arc-1 in the $\operatorname{dog}^{538}$. The cadherins are concentrated at the zonulae adherentes (cell-cell junctions) of epithelial cells and are associated with actin of the cytoskeleton via cytoplasmic proteins called catenins. "Three catenins have been described: $\alpha, \beta$ and $\gamma$ catenin with a molecular weight of respectively $102 \mathrm{kD}, 88 \mathrm{kD}$ and $80 \mathrm{kD}$. Binding of the cadherins via 
catenins is essential for cadherin function ${ }^{4064}$. As ourlined before, the APC gene product is also involved in this complex through binding with $\beta$-catenin ${ }^{\text {w }}$. The expression of $\mathbf{E}$-cadherin in carcinomas has been snudied extensively. In human tumour cell lines E-cadherin was found to act as an invasion suppressor ${ }^{\text {hat }}$. It has also been shown that phosphorylation of E-cadherin-catenin complex increases invasiveness in vitro ${ }^{\text {k. }}$.

\subsection{Differentiation}

\subsubsection{Normal colonic epithelium, the different cell lineages}

The colonic mucosa consists of crypts of Lieberkihn lined with a single layer of epithelium. The crypts are embedded in a loose stromal rissue and reach to the muscularis mucosae, which separates the mucosa from the underlying submucosa.

The lining epithelium shows three types of cells: columnar shaped absorprive enterocytes, mucin producing goblet cells and neuroendocrine cells. In case of inflammation and (pre)cancerous change, a fourth cell which normally occurs primarily in the small intestine is present, the lysozyme producing Paneth cell. Columnar cells have an important function in absorprion of merabolites, for which they have microvilli ar their luminal surface. Differentiated columnar cells synthesize secretory component, which is a glycoprotein with a molecular weight of $60-70 \mathrm{kD}$ serving as a carrier in the epithelial translocation of dimeric $\lg A$, which is subsequently secreted into the bowel lumen in defense against microorganisms. Antibodies against sectetory component are available to stain the differentiated columnar cells $s^{\text {sid }}$, s. $^{5}$.

Gobler cells secrete mucin for lubrication purposes and also to protect the epithelium against mechanical damage and chemical irritants. Colonic mucus is a molecular mixture in which sulfomucins predominate, but admixed with neutral and sialomucins and which can be stained with convential rechniques such as PAS, Alcian Blue and HID-AB stains. Also different monoclonal and polyclonal antibodies can be used for inmunohistochemical detecrion of mucin. Neuroendocrine cells synthesize polypepride hormones and through these modulate intestinal functions such as secrerion, absorption and motiliry. These cells can be recognized by monoclonal antibodies against the different polypeptide hormones or with monoclonal antibodies which recognize compounds in neurosecretory granules such as Chromogranine A. Also, histochemical techniques, amongst which silver impregnations are most widely used, have been developed ${ }^{6, s, 6 ?}$.

Paneth cells produce lysozyme, an enzyme capable to cause lysis of bacterial cell walls. Normally this cell can be found in the small intestine at the bottom of the 
crypt. During inflammarion and (pre) cancerous change, these cells are seen in colonic pithelium. Antibodies against lysozyme are avalable to stain Paneth cells.

As stated before, the markers associated with terminally differenciated cells, perhaps with exceprion of neuroendocrine markers, do not provide essential information about the clinical behaviour of colon tumours, probably because -also in a tumour-such differentiated cells are destined to go inco programmed cell death and do therefore not contribute to cumour growth and progression. Progenitor cells or stem cells, in contrast, are the cells that propagate and therefore derermine the fate of tissue, whether normal or malignant. Against this background markers of such cells might be more meaningful in the assessment of the clinical course and behaviour of tumours.

\subsubsection{Colonic stem cells}

For colonic mucosa, the presently held views regarding epithelial cell maturation were originally formulared by Cheng and Leblond ${ }^{\text {is }}$, who provided evidence that all cell types are derived from the same precursor cell, which they postulated to be the crypt stem cell. The stem cell is located at the bottom of the crypt and gives rise to daughter cells with proliferative potential. During movement upwards to luminal crypt position, proliferative capacity is lost and gradual differentiation takes place. Finally mature cells are shed into the bowel lumen. This so called unitarian theory was subsequently corroborated by experi-

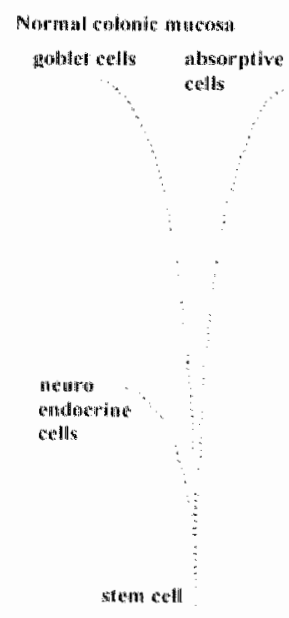

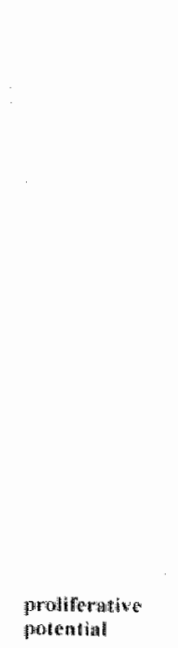

I Hamours

nell differentated

onoderuly differentiat ad

poorly differentinted

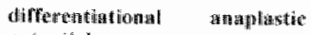

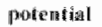

Figure 3. Differen atages of matignant Iransformation 
menal embryological studies, using the chicken-quail neural crest mansplanta* non rechnique. Recent studies by Park et al. also support the stem cell con cept.

\subsubsection{Differentiation and maturation of tumour cells. The tumour stem cell concept}

It is conceivable that in analogy with normal mucosa, tumours arise from a single (tumour) stem cell (Fig. 3). The popularion of tumour cells is indeed monoclonal . Several observations support the validity of the stem cell concept for neoplasms. Firsty, several case reports mention a wide spectrum of differentiation in adenocarcinomas . This could reflect the idea that these tumours originate from a pluripotent stem cell. Secondly, differentiation induction in colon cancer cell lines leads to reduced proliferative capacity , suggesting that only stem cells propagate and differentiated cells do not contribute to tumour growth. Thirdly, studies on subpopulations of cells from human cumours have shown that these may show a variable degree of proliferative capaciry, clonogenic porential and cell differentiation ${ }^{53-4}$. Finally, in clonogenic studies cloning efficiencies of turnour cell popularions as low as $0.001 \%$ are generally found ${ }^{m 23}$, suggesting that the proliferating tumour cell fraction in human rumours is small and could only be derived from a stem cell fraction.

The basic principle of the tumour stem cell concept is that a maturation arrest occurs at the moment of malignant transformation of a cell into a tumour cell. According to this concept the behaviour of a tumour reflecrs the proliferative and differentiarional potential of the cell, from which the tumou originates: when this transformed cell in its phase of development was stem cell like, the resulting tumour would be rapidly growing and poorly or undifferentiated. whereas in contrast a tumour arising from a differentiated cell would be slowly progressing and differentiated. Fig. 3 depicts the variations to be expected in the specrum of colorectal cumours according to proliferation and differentiacion. From this concept it is obvious that is is of paramount importance to search for stem cell makcers since these characterize highly malignant, metastasizing rumours. Therefore, markers for stem cells or "near" stem cells, and immaturc/not terminally differentated cells of the various lineages (columnar, goblet and netroendocrine) should be generated.

\subsection{Aim}

Colorectal carcinomas can be cured by complete excision of the tumour. Therefore, surgery is still the treatment of choice. Treament failure is thought to be caused by (minimal) residual tumour. It is essential, therefore, to identify ru- 
mours with high chance for incomplete removal. Aggressively behaving tumours, probably early metastasizing rumours, are the ones responsible for residual rumour and treatment failure.

In this contex the aim of this study was to contribute to the work of pathologists to better evaluate the clinical course and behaviour of especially very aggressive and metastasizing colorectal tumours. This was approached by two ways: 1) generation of markers of immature/scem cell(like) cells to hopefully enable the identification of tumours with a highly malignant prophile and behaviour and 2) study the expression of some essential molecules in the process of cell adhesion so as to possibly identify tumours with a metastasizing potential. Chapter 2 detailedly describes our efforts to generate monoclonal antibodies reacting to antigens related to immarure or stem cell (like) cells. The characterisrics of one of the obtained monoclonal antibodies are extensively reported in chapter 3.

Chapter 4,5 and 6 relate our experience with the studies of adhesion molecules. In chapter 4 the question is addressed whether invasive potential of primary cumours could be inferred from loss of E-cadherin expression. The hyporhesis that it could be possible that metastases arising from cells deficient in adhesion molecule expression also show reduced E-cadherin expression was studied in chapter 5. Finally in chapter 6 the impacr of the cadherin-catenin complex in metastatic behaviour was investigated.

\section{References}

1. Zwaveling A, Bosman FT, Schaberg A, velde CH' van de, Wagener DHH. Oncologie.

4th edition. Houten, 1988

2. Visser O, Gobergh IWW, Schouten $U$.

Incidence of cancer in the Netherlands.

4thedition. Utrecht, 1992

3. Wise WE, Padmanaphan A. Meesig DM, et al.

Abdominal colon and rectal operations in the elderly.

Dis Colon Rectum 1991, 34: $959-963$

4. Arnaud JP, Schloegel $M$, Olher JC, Adloff $M$ Colorectal cancer in patients over 80 years of age.

Dis Colon Rectum 1991, 34:896-898

5. Wiggers $T$, jeekell, Arends $W$, et al.

No-touch isolation technique in colon cancer: a controlled prospective trial.

Br J Surg 1988, $75: 409-415$ 
6. Frixen UH, Behrens J, Sachs $M$, et al

E-cadherin-mediated cell-cell adhesion prevents invasiveness of human carcinoma cells.

J Cell Biol 1991, 113:173-185

7. Matsuzaki F Mege RM, Jafte SH, et al.

CDNAs of cell adhesion molecules of different specificity induce changes in cell shape and border formation in cultured 5180 cells.

ICell Biol 1990, 110:1239-1252

8. James RD, Haboubi N, Schofield PF, Mellor P. Salhab N.

Prognostic factors in colorectal carcinoma treated by preoperative radiotherapy and immediate surgery.

Dis Colon Rectum 1991, 34:546-551

9. Moertel CG, Fleming TR, Macdonald IS, et al. Levimasole and fluorouracil for adjuvant therapy of resected colon carcinoma.

N Engl I Med 1990, 322: 352-358

10. Dukes CE.

The classification of cancer of the rectum.

I Pathol Bacteriol 1932, 35: 323-332

11. Tumbull RB, Kyie K, Watson FR, Spratt gentlemen.

Cancer of the colon: the influence of the no touch isolation technique on survival rates.

Ann Surg 1967, 166: $420-427$

12. Astler VB. Coller FA.

The prognostic significance of direct extension of carcinoma of the colon and rectum.

Ann Surg 1954, 139: 846-852

13. Blenkinsopp WK Stewart-Brown S, Blesowsky L, Kearney G. Fiedding LP Histopathologic reporting in large bowel cancer.

עClin Pathol 1981, 34:509-513

14. Pretlow TP, Keith EF, Keith Gryar A, et al

Eosinophit infiltration of human colonic carcinomas as a prognostic indicator.

Cancer Res 1983, 43: 2997-3000

15. Benchimol S, Fuks A, Jothy 5, et al.

Carcinoembryonic antigen, a human tumor marker, functions as an intercellular adhesion molecule.

Cell 1989, 57:327-334 
16. MCNeill H, Ozawa Memler $R$, Nelson WI.

Novel funcion of the cell adhesion molecule uwomorulin as an inducer of cell surface polarity.

Cell 1990, 62:309-316

17. Ho SE, itzkowitz SH, friera AM, Jiang $5 \mathrm{H}$, Kim YS.

Cell lineage markers in premalignant and malignant colonic mucosa.

Gastroenterology $1989.97: 392-404$

18. Arends $M$

Immunohistochemical studies in colorectal carcinoma.

Thesis, University of Limburg. Maastricht. 1984

19. Arends IW Wiggers T, Verstimen C, Bosman FT.

The occurence and clinicopathological significance of serotonin immunoreactive cells in large bowel carcinoma.

J Pathol 1986, 149:97-102

20. Hamada $Y$, Oishi $A$, Shoji $T$, et al.

Endocrine cells and prognosis in patients with colorectal carcinoma.

Cancer 1992, 69:2641-2646

21. de Brime AP, Wiggers T, Beek $C_{x}$ et al.

Endocrine cels in colorectal adenocarcinomas. incidence, homone profile and prognostic relevance.

Int J Cancer 1993, 54: 765-771

22. Ferrerro $S$, Buffa $R$, Pruneri $G$, et al.

The prevalence and clinical significance of chromogranin $A$ and secretogranin 11 immunoreactivity in colorectal adenocarcinomas.

Virchows Arch 1995,426:587-592

23. Liotta LA, Rao CN, Barsky $5 H$.

Tumor invasion and the extracellular matrix.

Lab Invest $1983,49: 636-649$

24. Bastida E.

The metastatic cascade potential approaches for the inhibition of metastasis.

Semin Thromb Hemost 1988, 14: 65-72

25. King IA, Magee Al, Rees DA, Buxton RS.

Keratinization is associated with the expression of a new protein related to the desmosomal cadherins DGll/ll.

FEBS Lett 1991, 286:9-12 
26. Springer $T A$.

Adhesion receptors of the immune system.

Nature 1990, 346: $425-434$

27. Barsky SH, Togo S, Garbisa S. Liorta LA.

Type IV collagenase immunoreactivity in imasive breast carcinomas.

Lancet 1983: 296-297

28. Evans $\mathrm{CW}$

Cell adhesion and metartasis

Cell Biol Int Rep 1992, 16:1-10

29. Liotta LA, Mandler R, Murano G, et al.

Tumor cell autocrine motility lactor.

Proc Natl Acad Sci USA 1986, 83:3302-3306

30. Liotta $L A$, steeg PS, stetter-Stevenson WG.

Cancer metastasis and angiogenesis: an imbalance of positive and negative regulation.

Cell 1991, 64:327-336

31. Starky /R.

Cell-matrix interactions during tumor invasion.

Cancer Metastasis Rev 1990, 9: 113-123

32. Fearon ER, Hamilton SR, Vogelstein $B$.

Clonal analysis of human colorectal tumors.

science $1987,238: 193-197$

33. Fearon ER. Vogelstein $B$.

A genetic model for collorectal tumorigenesis.

Cell 1990, 61:759m 767

34. Fearon ER, Jones PA.

Progressing toward a molecular description of colorectal cancer development.

Faseb I 1992, 6:2783-2790

35. Kinzler $K W$ Vogelstein $B$

Lessons from hereditary colorectal cancer.

Cell 1996, 87: 159-170

36. Bodmer WF, Bailey C, Bodmer, et al.

Localization of the gene for familial adenomatous polyposis on chromosome 5 .

Nature $1987,328: 614-616$

37. Rubinfeld B, Souza B. Abert 1, et al. Assaciation of the APC gene product with beta-catenin. 
Science $9993,262: 1731-1734$

38. SuLK, Vogelstein $B$, Kinzler $K W$.

Association of the APC Iumor suppressor protein with catenins.

science 1993, 262: 1734-1737

39. Morin PJ, Sparks AB, Korinek $V$, et al.

Activation of $\beta$-catenin-Tc signaling in colon cancer by mutations in $\beta$-catenin or $A P C$

science $1997,275,1787-1790$

40. Korinek $V$ Barker $N$, Morin Pl, et al.

Constitutive tramscriptional activation by a $\beta$-catenin-Tof complex in APC- 1 -colon carcinoma.

Science 1997, 275: 1784-1787

41. Perfer $M$

9-catenin as oncogene: the smoking gun.

Science 1997, 275: 1752-1753

42. Morrin PI, Vogelstein B, Kinzler KW

Apoptosis and APC in colorectal tumorigenesis.

Proc. Natl. Acad. Sci. USA 1996, 93: 7950-7954

22

43. Jen I, Kim H. Piantadosi S, et al.

Alelic loss of chromosome 189 and prognosis in colorectal cancer.

N Engl I Med 1994, 331:213-221

44. Freemont $T$.

The significance of adhesion molecules in diagnostic histopathology.

Current Diagnostic Pathology 1995, 2: 101-110

45. Butcher EC.

Leucocyte-endothelial cell recognition: three (or more) steps to specificity or diversity.

Cell 1991,67:1033

46. Springer TA.

Traffic signals for recirculation and leucocyte emigration: the multistep paradigm.

Cell 1994, 76:301-314

47. Aruffo A, Dietsch MT, Wan H, Hellstrom KE, Hellstrom I

Granule membrane protein 140 (GMP140) binds to carcinomas and carcinomaderived cell lines.

Proc Natl Acad Sci USA 1992, 89: 2292-2296 
48. Sawada $R$, Tsuoboi S, Fukada M

Differential E-selectin-dependent efficiency in sublines of a human colon cancer exhibiting distinct metastatic potentials.

J Biol Chem 1994, 269: 1425-1431

49. Stone IP, Wagner DD

P.selectin mediates adhesion of platelets to neuroblastona and small cell inng cancer.

J Clin invest 1993, $92: 804-813$

50. Doherty P. Ashton SV, Moore SE. Walsh FS.

Morphoregulatory activites of NCAM and N-cadherin can be accounted for by $G$ protein-dependent activation of $L$ - and $N$-type neuronal $C a 2+$ channels.

Cell 1991.67:21-33

51. Hynes RO

integrins: a family of cell surface receptors.

Cell 1987, 48: 549-554

52. Hymes RO.

Integrins: versatility, modulation, and signaling in cell adhesion.

Cell 1992, 69:11-25

53. Wielenga VM, Heider KH, Offerhaus GJA, et al.

Expression of CD 44 variant proteins in human collorectal cancer is related to tumour progression.

Cancer Res 1993, 53: 4754-4756

54. Mulder W, Kruyt PM, Sewnath $M$, et al.

Colorectal cancer prognosis and expression of exon-v6-containing CD44 proteins.

Lancet 1994, 344: 1470-1472

55. Takeichim.

Cadherin cell adhesion receptors as a morphogenetic regulator.

Science 1991,$251 ; 1451-1455$

56. Boller $K$, Vestweber $D$, Kemler $R$.

Cell-adhesion molecule wwomoruin is localized in the intermediate junctions af adult intestinal epithelial cells.

J Cell Biol 1985, 100:327-332

57. Imhof BA, Wollmers HP, Goodman SL, Birchmeier W.

Cell-cell interaction and polarity of epithelial cells: specific perturbation using a monoclonal antibody.

Cell 1983, 35:667-675 
58. Behrens J, Birchmerer W, Goodman SL, Imhof BA.

Dissociation of Madin-Darby canine kidney epithelial cells by the monoclonal antbody anti-arc-1: mechanistic aspects and identification of the antigen as a component related to uwomorulin.

I Cell Biol 1985, 101: 1307-1315

59. Ozawa $M$, Ringwald M, Kemler $R$.

Uwomorulin-catenin complex formation is regulated by a specific domain in the cytoplasmic region of the cell adhesion molecule.

Proc Natl Acad Sci USA 1990, 87: 4246-4250

60. Shimoyama $Y$. Nagaruchi $A$, Fujpa $S$, et al.

Cadherin dysfunction in a human cancer cell line: possible involvement of loss of alpha-catenin expression in reduced cell-cell adhesiveness.

Cancer Res 1992, 52:5770-5774

61. Morton RA, Ewing CM, Nagafuchi A, Tsukita S, Isaacs WB. Reduction of E-cadherin levels and deletion of the alpha-catenin gene in human prostate cancer cells.

Cancer Res 1993, 53:3585-3590

62. Verninckx K, Vakaet L Jr, Mareel M. Fiers W, van-Roy F. Genetic manipulation of E-cadherin expression by epithellal tumar cells reveals an invasion suppressor role.

Cell 1991, 66; 107-119

63. Behrens J, Vakaet L, Fris $R$, et al. Loss of epithelial differentiation and gain of invasiveness correlates with tyrosine phosphorylation of the E-cadherin/beta-catenin complex in cells transformed with a temperature-sensitive $v$-SRC gene.

J Cell Biol 1993, 120:757-766

64. O'Daly JA, Craig SW, Cebrall.

Localisation of $\beta$ markers, $\alpha$ chain and SC of sigA in epithelial cells lining Lieberkün crypts.

Jimmunol 1971, 106:286-288

65. Tourvilie DR. Adler RH, Bienenstock J, Tomasi TE.

The human secretory immunoglobuln system: immunohistological localization of $A$. secretory plece and lactoferrin in normal human tissues.

I Exp Med 1969, 129:411-426

66. Masson P, Roux E

La glande endocrine de l'intestin chez lhomme.

CR Acad Sci (Pans) 1914, 158:59-61 
67. Grimelius L.

The argyrophil reaction in islet cels of adul human pancreas studied with a new silw ver nitrate procedure.

Acta Soc Med Upsal 1968,73:271:294

68. Cheng $H$, Leblond $C P$.

Origin, differentiation and renewal of the four man epithelial cell types in the mouse small intestine.

I-V. Am J Anat 1972, 141:461-562

69. Andrew A.

APUD cells in the endocine pancreas and the intestine of chick embryos.

Gen Comp Endocrinal 1975, 26: 485-495

70. Park HS, Goodlad RA, Wright NA.

Crypt fission in the small intestine and colon. A mechanism for the emergence of G6PD locus-mutated crypts after treatment with mutagens.

Am J Pathol 1995, 147: 1416-1427

71. Damjanov 1, Amenta P, Bosman FT.

Undifferentiated carcinoma of the colon containing exocrine, neuroendocrine and squamous cells.

Virch Arch Pathol Anat 1983, 401:57-66

72. Novello P, Duvillard P, Grandjowan S, et al.

Carcinomas of the colon with multidirectional differentiation.

Dig Dis Sci 1995, 40:100-106

73. Meyer IS, Rao BS, Stevens SC, White $W$.

Low incidence of estrogen receptor in breast carcinomas with rapid rates of cellular replication.

Cancer 1979, 40: $2290-2298$

74. Turowski GA, Rashid Z, Hong F, Madri JA, Basson MD.

Glutamine modulates phenotype and stimulates proliferation in human colon cancer celllines.

Cancer Res $1994,54: 5974-5980$

75. Sakamoto K, Venkatraman G. Shamsuddin AM.

Growth inhibition and differentiation of HT-29 cells in vitro by inositol hexaphos-

phate (phytic acid).

Carcinogenesis 1993, 14:1815-1819

76. Zhao $X$, Feldman D

Regulation of vitamin $D$ receptor abundance and responsiveness during differentiation of HT-29 human colon cancer cells.

Endocrinology 1993, 132: 1808-1814 
77. Baghidiquan 5 , Verrier B, Gerard C, Faninigentiemen

Insulin like growth factor Is an autocrine regulator of human colon cancer cell differentiation and growth.

Cancer lett 1992,62:23-33

78. Mackillop W. Stewart SS. Buick through

Densitydvolume analysis in the study of cellular heterogeneity in human ovarian carcinoma.

Brit d Cancer 1982, 45: 812-820

79. Bizzari JP. Mackillop Wl, Buick RN

Cellular specificity of NB70K, a putative human owarian antigen.

Cancer Res 1983, 43: 864-867

80. Hzkowitz SH, Shi ZR, Kim YS.

Heterogeneous expression of two oncodevelopmental antigens, CEA and SSEA-1, in colorecial cancer.

Histochem / 1986, 18:155-163

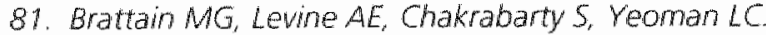
Heterogeneity of human colon carcinoma.

Cancer Metastasis Rev 1984, 3: 177-191

82. Takeichi $M$.

Cadherins: a molecular family important in selective cell-cell adhesion.

Annu Rev Biochem 1990, 59: 237-252

83. Nelson W, Shore EM, Wang AZ, Hammerton RW.

Identification of a membranewcytoskeletal complex containing the cell adhesion molecule uvomorulin (E-cadherin), ankyrin, and fodrin in Madin-Darby canine kidney epithelial cells.

J Cell Biol 1990, 110: 349.357 
Chapter 2

\section{Colonic crypt isolation and production of anti-crypt cell antibodies}

Anna A.M. vary der Wurf, Winand N.M. Dinjens, Edith P.M. wan der Linden, Patrick T.J. Marx, Loop ten Kate, Jan-Willem Arends and Fred T. Bosman. 


\section{Introduction}

In order to obtain monoclonal antibodies specific for a defined molecule or a topographically or functionally defined rissue structure either a well defined anagen has to be used in the process of immunizarion or a suitable rest system has to be wsed to select the antibody wh the desired specificity subsequent to immunization with an ill defined immunogen. In the serting of our desire to obtain crype stem cell specific antibodies this implied either the availability of crypt stem cell specific antigens or a test system which would allow us to select for crype stem cell specific immunoreactivity. Crypt stem edls in the colon are not well defined and therefore antigens specific for these cells are nor avalable. In principle, immunohistochemistry would be the method of choice for seleccion of appropriately immunoreactive hybridomas, as crype stem cells are topographically defned. In practice, common crype cell anrigens are so dominant that ir would require an inordinate effort ro select an antibody by immunohistochemistry, following immunization with unselecred crypr cell antigens. We rherefore set out ro eliminate common crype cell antigens during or pror to immunization, in order to limit the spectrum of obtained immunoreactivities. To reach this goal the following approaches were chosen:

1) selection of specific crypt cell subpopulations. This was done by differential harvescing of enzymarically digested colon mucosa and by cell culture techniques, using cell lines in different stages of maturation.

2) ancibody blocking of common crypt cell antigens and

3 ) in vivo selection of the immune response using cyclophosphamide.

The antigenic mixture was injected intrasplenally into mice, because in this way we hoped the immune system would even recognize wealdy immunogenic antigens.

In this chapter the results of these efforts are described.

\section{Materials and methods}

Selection of specific crypt cell subpopulations

The problem of antigen selection was appronched in rwo ways. First, we atrempred to isolate the basal crypt cells to be used for immunization. In addition, differentiated and undiferentiated colorectal cancer cell lines were used as antigenic mixtures.

Cypt base cell asolation: Human colonic cryprs were isolated from surgical coleccomy specimens according to Whitehead et al." . Normal looking mucosa ar least at five cm distance from the rumour was excised and placed in a sterile perridish containing 1 mmol/ EDTA, $\mathbb{m}$ mol/ anyleneglycol-bis-(B-aminoedhyl 
ether)-N,N,N,N-teraacetic acid (EGTA)(Sigma chemical company, St. Louts. MO) and $0.5 \mathrm{mmol} / \mathrm{D}$ DT in PBS (Phosphate Buffered Saline pH $\mathrm{H}=7.4$ ) (30 min RT). Next the tissue was put in a conical centrifuge tube with sterile PBS and shaken vigorously by hand. The crypes liberared by this procedure were hatvested by gentle centrifugation $(\mathrm{g}=100$ ) and lysed with lysis buffer containing 5 mmol/ NaHPO, 1 mmol// EDTA, 1 mmol/ $\beta$ mercaptoethanol. $0.125 \%$ $\mathrm{m} / \mathrm{m}$ deoxycholate, $0.125 \% \mathrm{w} / \mathrm{v}$ Trion $\mathrm{X}-100.250 \mathrm{mmol} / \mathrm{sucrose}(\mathrm{pH}=6.4)$ mixed with procease inhibitors ( 1 momol/I PMSF, 2 mmol/1 NEM).

In order to obtain the lower part of the colonic crypt epithelium, including the crypt base stem cells, the mucosa was incubated, after decontaminarion with $0.04 \% \mathrm{~m} / \mathrm{v}$ Natriumbypodaloride in PBS (15 min, RT), with $0.05 \mathrm{mmol}$ EDTA in CMF-HBBS $\left(30 \mathrm{~min}, 37^{\circ} \mathrm{C}\right.$ ) in a spinner flask (Gibco) acoording to Ten Kate et al. . This supernatant yields single, more luminally located epithelial cells. The mucosa with the remaining basally located epithelium was subsequendy incubated as described above to yield crypt botrom parts.

Cell culture: In our immunizations we also used cells from the colon cancer cell lines $\mathrm{HT}-29, \mathrm{CaCO}$ and NCI-H716. HT-29 and $\mathrm{CaCO}$, an differentiate in vitro; NCI-H7 16 is an undifferentiated cell line. In order to mainain HT-29 cells undiferentiated, galactose instead of glucose was added to the medium (DMEM supplied with 5\% $\mathrm{FCS})^{3}$. $\mathrm{CaCO}$, cells remain undifferentrated in exponential growth. NCL-H716 cells grow in suspension and do not differentiare in vitro".

\section{Immunization}

Immunization was done by injection of antigens directly into the spleen of Balb/c mice, thus, we reasoned, enabling the immune system of the mouse to recognize even weakly immunogenic antigens. "To avoid rupure of the spleen, the mice reciwed one injection into the splecn 72 hours prior to fuston.

Mice were immunized with lysates of undifferentiated cells from cell lines and from human colon tissue. Also specific approaches like blocking of common crype cell antigens and in wivo selection of the immune respons were used. Blockng of fommon crypt coll antigens: As antigenic mixtures, undifferentiated $\mathrm{CaCO}$, cells, undifferentiated HT-29, NCI-H716 cells and crype botrom epithelium was used. These mixtures were lysed in buffer containing $5 \mathrm{mmol} / \mathrm{L}$. $\mathrm{NaHPO}, 1 \mathrm{mmol} / \mathrm{L}$ EDTA, $1 \mathrm{mmol} / \mathrm{L}$-mercaprochanol, $0.125 \%(\mathrm{~m} / \mathrm{m}) \mathrm{de}$ oxycholate, $0.125 \%(\mathrm{v} / \mathrm{v})$ Triton $\mathrm{X}-100,250 \mathrm{mmol} / \mathrm{L}$ sucrose $(\mathrm{pH}=6.4)$ mixed with provease inhibitors (1 mmol/L phenylmethylsulphonyl fuoride (Sigma), 2 mmol/L Nethylmaleimide (Sigma). To block common crype cell anrigens, the lysate was repeatedly mixed with antisera against colonic epitholium generated in mice ( $1 \mathrm{ml}$ lysate was mixed with $40 \mu \mathrm{l}$ undiluted antisera) and with mono- 
clonal antibodies against common antigens $(50 \mu)$ spent hybridoma culture medium) i.e. the anti-mucin ancibodies Parlam 9 and $10^{3}$. Bound antibodies were precipitated with Sepharose protein A (Pharmacia). $100 \mu l$ of the remaining supernarant was injected into the spleen of $\mathrm{Balb} / \mathrm{C}$ mice.

In vino selection of the immune responste: Ten minutes after intraperitoneal administration of differentiated $\mathrm{HT}-29$ or $\mathrm{CaCO}_{3}$ cells or differentiated human colon epithelial cells harvested afrer 30 minutes of cell isolation', mice were injected with cyclophosphamide $(100 \mathrm{mg} / \mathrm{kg})$ given intraperitoneally in saline. The same dose of the drug was administered at 24 and 48 hours. The same cyclophosphamide administration scheme was repeared every two weeks until after three treatments mice were bled from their tails. Sera were rested by immunohistochemisury on sections of small and large human intestine for the presence of polyclonal antibodies and weak immunoreactivity of sera of mice immunized with cyclophosphamide trearment was noted in comparison to sera of mice without cyclophosphamide treatment. A final boost with undifferentiated $\mathrm{H}^{\mathrm{T}} \mathrm{T}-29$ cells, CaCO cells or undifferentiated crypt bottom epirhelial cells was given 72 hours prior to fusion. This immunizaton protocol is drawn schematically in Table I.

\section{Fusion protocol}

Fusion was done according to Köhler and Milstein". In short, spleen cells were fused with Sp 2-0 myeloma cells using PEG 4000 (Merck, Darmstadt) in a ratio $2: 1$, seeded in 96 well microtiter plates and grown on DMEM, 20\% FCS, 2\% HAT (Boehringer, Mannheim), 2\% penicilline and strepramycine, $2 \%$ glutamine and $1 \%$ pyruvate. Hybridomas were cloned by limiting dilution.

Table I.

Immunizaton (to o) with differentiated sells

$1=10 \mathrm{~min}$

t: 24 hrs

syclophosphamide $100 \mathrm{mo} / \mathrm{kg}$ intrapertoneally

ted8 hivs

10.

ld

Repeat every wo weeks.

Final immunization 72 hrs prio to fusion) with undifferentiated cells 


\section{Antibady selection}

Secrions of echanol fixed and paraffin embedded normal large and small intestinal epirhelium were made, each piece placed ar such a distance that 5 consecutive secrions could be placed on one glass slide. Supernatant of all 96 wells of each microtiter plate was tested by an indirect inmunoperoxidase merhod and hybridomas producing antibodies with a differential staining partern were cloned and recloned by limired dilurion to obtain monoclonal antibodies.

\section{Results}

Selection of specific crypt cell subpopulations

We succeded to preferentially isolate crypt base cells with the method of Whitehead er al.'. Combined with the method of Ten Kate et al." also superior crypt cells could be isolared. Also cultured cells including differentiated and undifferentiated HT-29 and $\mathrm{CaCO}$, cells and undifferentiated NCI-H716 cells were used as antigens.

\section{Antibody selection}

Immunization had to be performed with complex antigen mixtures because antigens of interest i.e. antigens of undifferentiated (stem) cells, are as yet not defined. Lacking such a defined antigen, a quick ELISA test could nor be performed and an alternative test method had to be developed. We used ethanol fxed tissue sections, as described by Dinjens er al. in order ro approwimate the native state of the rissue, and proteolytic enzyme digestion to find immunoracvivity on formalin fixed tissues.

\section{Antibodies obtained}

Simple immwrization: At least thirty mice were immunized wich cell homogenates either from cell lines or from human colon crypts withour addicional eforts to tailor the immunoreactivity. Most obtained hybridomas showed variably intense unselective staining of mucosal cells. Antibodies with a differential staining pattern are summarized in Table II. One of the developed antibodies, obtained after immunization with undiferentiated HT-29 cels, did show immunoreactivity at the botton of the crypts of the small incestine. This antibody (IVF3) appeared to recognize a protein present in Paneth cells, probably lysozyme. Also two antibodies were developed after one intrasplenal injection of cells from the celline NCI-H71.6, recognizing respectively enterocyces all along the crypt and endothelial cells (monoclonal antibodies $10 \mathrm{Fg}$ and $4 \mathrm{AB}$ ). Both appeared to be of $1 \mathrm{gMK}$ subtype. $10 \mathrm{~F} 9$ reacted wich formaline fixed rissues after pepsine digestion. This antibody is directed against a peptide epitope with a molecular weight of $54 \mathrm{kD}$. A last example of an antibody developed with this 
Table II.

\section{procedure}

HT-29 undifferentiated

NCIHOI6

$\mathrm{ACH}+\mathrm{H})$

$\mathrm{CaCO}$, undifferentiated

slocking of antigens.

cyclophosphande

NO = not determined antibody

\section{WP}

$10 \mathrm{rg}$

$4 \mathrm{A3}$

$6 B 354$

$5 E 9$

208 sotype

N.D.

$19 \mathrm{Mk}$

$\lg M x$

lgMh

$\operatorname{lgM} \mathrm{x}$

N.D. pattem

paneth cells enterocytes endothentum nucle: "immature" goblet cells CEA

method (6B3F4), was obtaned after one intrasplenal injection of undifferentated $\mathrm{CaCO}$, cells.6B3F4 stains nuclei of all colonic crypt epithelial cells and is of $\operatorname{lgMK}$ class.

Blocking of common crypt cell whens. Using anri-mucin antisera as blocking agents, one interesting antibody was developed (5E9). This antibody shows immunoreactivity with goblet cells in the lower half of the crypts in the large intestine and is of $\mathrm{IgMK}$ class. Biochemical characterization revealed that this antibody recognizes a carbohydrate (O-glycan) epitope on Muc2. An extensive description is given in chapter 3 of this thesis.

Ir wise selection of the immune system: The cyclophosphamide elimination strategy in the end proved to be too toxic: of a total of 10 mice immunized with the cyclophosphamide protocol. 7 died during the treatment. Of the remaining chree mice, sera yiclded polyclonal antibodies with weak immunoreactivity after three treaments of in toral 9 cimes a dosis of $100 \mathrm{mg} / \mathrm{kg}$ cyclophosphamide. Ideally, the cyclophosphamide treatment would have to be repeated untill the immune sera would no longer show immunoreacrivity rowands the antigen mixture, but in our hands not one single mouse did survive following this protocol. Therefore, we decided to limit the cyclophosphamide rreatment to thee cycles. and followed with an injection of undifferentiated cells. One of the hybridomas we isolated showed immunoreacrivity aganst carcinoembryonic antigen (CEA) (2C8).

\section{Discussion}

In onder to obtain antibodies against antigens associated with undefined and less common antigens, such as undiferentiated cells, different approaches are avail. 
able. The first and the most direct approach to produce monoclonal antibodics against rare antigens present as a small proportion of the total concent of a protein mixture is popularly known as the shotgun approach ${ }^{\mathrm{x} .2}$. In this most simple protocol, the mixture of proteins, induding the protein which is the presumed target antigen is used to immunize the animal. The obtained hybridomas are screened often by reactivity patterns to cells or rissues. Here the chance of success is a question of numbers: the higher the number of hybridomas tested, the higher the chance to find what is desired. Two additional factors affect the success of the method. The first is the fracrion of the targer anrigen within the rotal protein mixture. If the protein of interest only makes up a very small proportion of the mixture, the number of hybridomas to be tested would, statistically, have to be very large. The second is the immunogenicity of the desired protein in comparison with the other proteins in the mixture. If the protein of interest is wealdy immunogenic compared to the other antigens in the mixture, a favourable ourcome of the enterprise is rather unlikely. The shorgun approach did yield antibody producing clones, but none with the desired staining partern of crypt stem cells. This might be due ro - 1 - feeble presence of crypt stem cell specific anrigens and -2-weakly immunogenic crypt stem cell ancigens compared to the other antigens in the lysate. Given the very restricted number of crypt stem cells their low quantity might have been insufficient to elicit an immune response.

The second method involves the use of blocking antibodies. In this approach, an initial immunization will generate antibodies against all antigens in the lysate of differentiated cells". Then, a lysate of the undifferentiared cells is incubated with this antiserum and the mixture is used to immunize a second series of mice. In theory, using this method, the production of desired immunoreactivities is favored because the inirially generated antiserum will block the generation of immunoreacrivities recognizing differentiated cells. The exact mechanism responsible for the presumed rescriction of the immune response is not known, bur Jerne's nerwork hypothesis could explain how this might accur. The added antiserum induces synthesis of anti-idiotypic ancibodies, which prevent generittion of ancibodies with immunoreactivitics crossreacting with those in the initial antiserum. This method has as advantage that it allows a certain tailoring of the immune response contrary to the shotgun approach. It does require, however, the availibility of a set of closely homologous proteins of which one does while the other does not have the targer antigen. This procedure resulted in an antibody recognizing goblet cells in the lower half of the crypt (5E9). Its propertics will be described extensively in chapter 3 of this thesis.

As third method we used the cyclophosphamide elimination strategy". This approach is based on the clonal expansion of B lymphocytes during the expansion 
phase of a humoral immune response. These rapidly dividing cells can be preferentially killed using cyclophosphamide. A procedure for selective elimination of lymphocytes through the use of cyclophosphamide has been developed by Matthew and Sandrock". Essentially, in this procedure mice are immunized intraperitoneally with the antigenic preparation containing a complex mixture of antigens but withour the target antigen. After boosting, cyclophosphamide is administered and subsequently the antigen of interest will be injected. This procedure yielded one interesting immunoreactiviry pattern. Upon characterization of this antibody it appeared to recognize CEA. We had to abandon this attractive strategy because it appeared to be too toxic: few of our mice survived. As we had no defined antigen, immunization was done with cell lysares. In order to find an interesting hybridoma we had ro test on tissue sections, as our stem cells are largely topographically defined. Ideally, in order to approximate a native state of the antigens, immunohistochemistry should be performed on fresh frozen colonic mucosa. However, because of the complexity of such an approach, we decided to use ethanol as a fixative and embed the tissue in paraffin. Tissue fixation as well as paraffin embedding reduce the immunoreacrivity of an antigen ${ }^{1.14}$. Some antigens detectable in small quantity in fresh frozen tissue may be completely lost during routine processing and paraffin embedding. While no single fixative is ideal for all antigens, sacisfactory results for many different antigens can be obtained following fixation in buffered formalin, provided that the exposure to this fixative is limited to a few hours ${ }^{15,4}$. Also denaturing bur non-cross linking fixatives, as for example ethanol, can be used to retain antigens immunoreactivity. Ethanol better preserves proteins but tissues fixed in ethanol undergo marked shrinkage and the resulting morphology is poor.

In principle, the test substrate for hybridoma selection should be treated identical to the substrate on which the hybridoma will be used. As in parthology the test substrate mostly is formalin fixed paraffin embedded tissue it would have been consistent to use such material. We chose ethanol fixed tissue in order to expand the number of interesting hybridomas, on the assumption that crosslinking due to formalin fixation would be more destructive than erhanol fixation and immunoreactivity of formalin fixed epitopes might be retrieved using protease digestion or microwave hearing of tissue sections. Based upon our experience, which clearly is nor a systematic evaluation of immunization protocols, we conclude that anribody mediated tailoring of immunization is a promising approach towards increasing the specificity of immunization with non defined antigens. In general, the choice of immunization protocols will be determined empirically and guided by the requirements of cach specific experiment. 


\section{References}

1. Whitehead RH, Brown A, Bhathal PS.

A method for the isolation and culture of human colonic crypts in collagen gels.

In Vitro Cell Dev Biol 1987, 23: 436-442

2. Ten Kate 1 , Verspaget $H$, Wijnen J, et al.

Maturation dependent changes in nucleoside phophorylase (NP), adenosine deamnase (ADA) and ADA complexing protein (ADCP) in intestinal epithelial cells. In: Prow ceedings of the 32 nd Colloquium Protides of the Biological Fluids.

oxford, $1985: 339-342$

3. Pinto M, Appay M, Simon-Assmann S, et al.

Enterocytic differentiation of cultured human colon cancer cells by replacement of glucose by galactose in the medium.

Biol Cell 1982, 44:193-196

4. de Brume AP, Dinjens WNM, Pijls MM, et al.

NCH.H716 cells as a model for endocrine differentiation in colorectal cancer.

Virchows Archiv B Cell Pathol 1992,62: 311-320

5. Verstinen CP, Arends JW, Moerkerk PT, et al

Colonic epithelium reactive monoclonal antibodies. Identification and immunohistochemical localization of the target epitopes.

Histochemistry 1989, 92:397

5. Köhler $G$, Milstein $C$.

Continuous cultures of fused cells secreting antibody of pre-defined origin.

Nature 1975, 256: 495-497

7. Dinjens WMM, Linden van der EPM, Signet $C$, et al.

Solid phase adsorption af antigens for efficient production of antibodies reactive with native and fixed tissue antigens.

IImmunol Methads 1990, 126: 175-182

8. King SW, Morrow KJ Ir.

Monoclonal antibodies produced against antigenic determinants present in complex mixtures of proteins.

Biotechniques 1988, 6: 856-861

9. Chaffin WL, skudlarek I, Morrow KJ.

Variable expression of a surface determinant during proliferation of Candida albicans.

infect Immun 1988, 56:302-309 
10. Barday SL, Smith AM.

Rapid isolation of monoclonal antibodies specific for cell surface differentiation antigens.

Proc Mall ACad SC USA 1986, 83:4336-4340

11. Rolinghof $M$, Starzinski-Powitz $A$ ffizenmaier $K$, Wagner $H$. Cyclophosphamide-sensitive Tlymphocytes suppress the in vivo generation of antigen-specific cytotoxic T lymphocytes.

The Joumal of Experimental Medicine 1977, 145: 455-459

12. Matthew WD. Sancrock AW.

Cyclophosphamide treatment used to manipulate the immune respons for the production of monodonal antibodies.

J Immunal Methads 1987, 100:73-82

13. Hancock WW Becker Js, Atkins RC.

A comparison of fixatives and immunohistochemical techniques for use with monoclonal antibodies to cell surface antigens.

Am J Clin Path 1982, 78:825-831

14. Leong AS, Milios J Duncis CG.

Antigen preserwation in microwave-irradiated tissues. A comparison with routine formalin fixation.

J Pathol 1988, 156:275-282

15. Takeichim.

Cadherins: a molecular family impotant in selective cell-cell adhesion.

Annu Rev Biochem 1990, 59: 237-252

16. Ozawa $M$, Kemler $R$.

Molecular organization of the uwomorulin-catenin complex.

I Cell Biol 1992, 116:989,996

17. Taylor $C R$ Cote $R$.

Immunomicroscopy: A diangostic tool for the surgical pathologist.

znd edition. Vol 19. Philadelphia, London, Toronto, Montreal, Sidney, Tokio, 1994 
Chapter 3

\section{Expression of a marker for colonic crypt base cells is correlated with poor prognosis in human colorectal cancer}

Anneke A.M. van der Wurff "Joop ten Kate, Patrick T.J. Marx, Edith P.M. van der Linden, Cor C.L. Beek, Floris-Jan Bovelander, Jan Dekker, Winand N.M. Dinjens. Maarten F. won Meyenfeldt, Jan-Wilem Arends, and Fred T. Bosman. 


\section{Introduction}

In colorectal cancer, numour stage as expressed in the Dukes classificarion is still one of the best prognostic indicators. However, the behaviour of individual tumours within one stage is nor uniform and therefore addirional prognostic facwors are recded for more accurate determination of tumour behaviour. One such prognostic indicaror is histological grading which is howewer subjective and of limited significance.

In search for independent prognostic indicators, in addition to proliferation, oncogene status and ploidy, differentiation markers have been developed for the cell lineages in the colonic epithelium, which include columnar cells, mucin producing goblet cells and neuroendocrine cells. In a large series of colorectal adenocarcinomas, markers for end stages of differentation did not seem to thave prognostic value. Only neuroendocrine markers correlated with worse prognosis ${ }^{4,5}$ which might reflect the relatiwe immarurity of these cells, which are located basally in the crypt.

All colonic epithelial cells are thought ro arise from a common progenitor cell. the stem cell which is located at the borton of the crypt and gives rise to daugher cells with proliferative capaciry. During movement upwards to the direction of the lumen, the proliferative abilicy of the committed precursor cells for each of the three cell lineages is lost and gradual differentiation takes place. The fully differentiated cells are eventually shed into the bowel lumen.

For normal large bowel mucosa the stem cell concept appears valid and has gained wide acceptance. For carcinomas several observations support this concept. Firstly, in a small proportion of colorectal carcinomas a wide spectrum of differentiation has been found ${ }^{10.11}$. These findings are strongly in fawour of the origin of these tumours from a mulcipotential stem cell and these "stem cell" carcinomas seem to have a particularly unfavourable prognosis. Secondly, in colon cancer cell lines induction of differentiation reduces the proliferation in

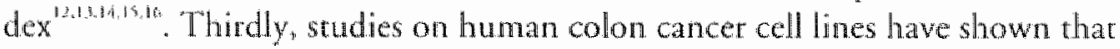
these mat exhibit a variable degree of proliferative activity, clonogenic porenrial and cell diferentiation . Finally, clonogenic assays generally show cloning efficiencies of rumour cell populations as low as $0,001 \%{ }^{23}$, suggescing that the prohiferang tumour cell fracrion in human tumours is small.

Our working hypothesis is that in analogy with normal colonic mucosa, in colorectal cancer tumour stem cells exist. The proliferative capacity and stage of maturation of the cumour stem cells would be an important determinant of tumour behaviour: the more immature the tumour stem cell, the higher the proliferation index and the less differentiated and the more aggressive the tumour. "To test the validiry of this concept, we set out to generate monoclonal antibod- 
fes, which selectively stain crypt base cells, assuming that antigens in immarure crypt base cells might also be expressed in colonic adenocarcinomas. In this paper, we describe the generation and chafacterization, by way of immunohistochemistry and immuno- and biochemical analysis, of a new monoclonal ancibody, 5E9, which selectively stains goblet cells in the lower half of the colonic crypt. The prognostic significance of its immunoreactiviry was tested on a large series of colorecral adenocarcinomas. High expression of the 5 E9 epitope appeared to be correlated with a tendency for poor prognosis in Dukes stage B3 patients.

\section{Materials and methods}

Monoclonal antibody production. As a source of colon crypt epithelial cells, we used mucosa from neoplastic as well as non-neoplastic colectomy specimens. In case of specimens resected because of cancer, mucosa at least at five cm distance of the rumour was used. This was incubared, after decontamination with $0.04 \%$ $(\mathrm{m} / \mathrm{v})$ Sodium hypochlorite in PBS and $0.5 \mathrm{mmol} / \mathrm{L}$ DTT in PBS ro free the sample of mucus, with $0.05 \mathrm{mmol} / \mathrm{L}$ EDTA in callcium and magnesium-free Hanks balanced salt solution (CMF-HBSS, Gibco, Paisley, Scotland) in at spinner flask (Gibco) according to Ten Kate et al. ${ }^{2}$. The mucosa with the remaining crypt bottom parts was incubated according to Whitelead et al. ${ }^{23}$ in a sterile

petridish containing $1 \mathrm{mmol} / \mathrm{L}$ ethylenediamineretraaceric acid (EDTA, Merck, Darmstadt, Germany), $1 \mathrm{mmol} / \mathrm{L}$ ethyleneglycol-bis-( $\beta$-aminoethyl ether) N, N'-terraacetic acid (EGTA, Sigma Chemical Company, St. Louis, MO) and $0.5 \mathrm{mmol} / \mathrm{L}$ dithiorreitol (DTT, Sigma) in phosphate buffered saline (PBS, $\mathrm{pH}=7.4), 30 \mathrm{~min}$ at room temperature. The crypts were liberated by vigorous shaking and harvested by centrifugation. The cells were lysed in buffer containing $5 \mathrm{mmol} / \mathrm{L}$ NAHPO, $1 \mathrm{mmol} / \mathrm{L}$ EDTA, $1 \mathrm{mmol} / \mathrm{L} / \beta$-mercaptoethanol. $0.125 \%(\mathrm{~m} / \mathrm{m})$ deoxycholate, $0.125 \%(\mathrm{v} / \mathrm{v})$ Triton $\mathrm{X}-100,250 \mathrm{mmol} / \mathrm{L}$ sucrose $(\mathrm{pH}=6.4)$ mixed with protease inhibitors ( $1 \mathrm{mmol} / \mathrm{L}$ phenylmethylsulphonyl fluoride (Sigma), $2 \mathrm{mmol} / \mathrm{L}$ N-ethylmaleimide (Sigma)). To reduce the availability of major mucin antigens ${ }^{24}$, the lysate containing the crypt botrom epithelium was incubated with antisera against colonic epithelium generated in mice and mixed with monoclonal antibodies against colonic mucins (Parlam 9 and $10)^{25}$. Bound antibodies were precipitated with Sepharose protein A (Pharmacia, Uppsala, Sweden)(1 hr $4^{\circ} \mathrm{C}$. Balb/c mice were immunized intrasplenally with $200 \mu \mathrm{L}$ of the final lysate, $72 \mathrm{hr}$ prior to fusion. As repeated intrasplenal immunizations appeared not to be feasible, due to a high chance of rupture of the spleen, the mice were immunized only once. Spleen cells were fused with Sp $2-0$ myeloma cells and selected using standard procedures ${ }^{36}$. Supernatant was tested 
on sections of normal colon and small bowel rissue specimens fixed in alcohol $70 \%$ as described by Dinjens er al. . $^{27}$ to avoid epirope destruction by aldehyde fixation. Antibody producing wells were cloned and recloned by limiting dilution untill all clones were productive. Isotyping was performed by immunohistochemistry on colonic epichelium using isorype specific secondary antibodies (Mouse typer, Biorad, Richmond). Specific positive and negative controls for each of the heavy and light chains were used.

Imomunoreactivity. Normal adult human tissues and umours were retrieved from our files. Of each tissue, at least two specimens were rested and all rissues were obtained fresh, fixed in $4 \%(\mathrm{v} / \mathrm{v})$ buffered formalin, dehydrated and embedded in paraffin. Also, frozen rissue specimens were used. Sections of $4 \mu \mathrm{m}$ thickness were cut and stained with an indirect immunoperoxidase technique. For antigen retrieval, sections were digested with proteases $\left(15 \mathrm{~min} 37^{\circ} \mathrm{C}\right)$ in concentrations ranging from $0.4 \%$ to $0.025 \%\left(\mathrm{~m} / \mathrm{v}\right.$ ) for trypsin (in $0.4 \% \mathrm{CaCl}_{2}$, $\mathrm{pH}=7.8)$ and pepsin $(0.1 \mathrm{~mol} / \mathrm{L}$ HCl). Also, pronase in $0.05 \mathrm{~mol} / \mathrm{L}$ Tris $\mathrm{HCl}$ $(\mathrm{pH}=8)$ was tested in concentrations of $0.04 \%$ to $0.0025 \%(\mathrm{~m} / \mathrm{v})(30 \mathrm{~min}$ $37^{\circ} \mathrm{C}$ ). Immunoperoxidase staining was performed using rabbit anti-mouse $\operatorname{lgG}$ conjugated to horseradish peroxidase as detection system and diaminobenzidine(DAB)- $\mathrm{H}_{2} \mathrm{O}$, as chromogenic substrate. For post-embedding immunoelectron microscopy, $1 \mathrm{~mm}^{3}$ fragments of human colon mucosa taken from freshly obtained surgical specimens were fixed in 0.1 mol/L phosphate buffer $(\mathrm{pH}=$ 7.2) containing $1 \%(\mathrm{~m} / \mathrm{v})$ acroleine and $0.4 \%(\mathrm{~m} / \mathrm{v})$ glutaraldehyde at $4^{\circ} \mathrm{C}$ for 4 hours. Tissues were transferred and stored in a sucrose buffer of $1 \mathrm{~mol} / \mathrm{L}$ sucrose in $0.1 \mathrm{~mol} / \mathrm{L}$ phosphate buffer $(\mathrm{pH}=7.2)$ with $1 \%(\mathrm{v} / \mathrm{v})$ paraformaldehyde at $4^{\circ} \mathrm{C}$ until further processing for standard Lowicryl embedding ${ }^{2 .}$. After impregnation of the rissues with Lowicryl K4M (Baltzers, Liechtenstein) polymerization was performed under UV exposure at $-35^{\circ} \mathrm{C}$. Ultrathin sections were first incubated with $10 \%(\mathrm{v} / \mathrm{w})$ normal goat serum (NGS, Dakopats, Glostrup, Denmark) in PBS (30 min at room temperature), second with the primary antibodies ( $1 \mathrm{~h}$ at room temperature) and finally with $10 \mathrm{~nm}$ colloidal gold-labeled goat-anti-mouse antiserum (GAM-10, Aureon, Wageningen, The Netherlands) under microwave irradiacion at $150 \mathrm{~W}$ for $30 \mathrm{~min}$. The immunogold-silver enhancement was done by magnification of the gold particles by precipitation of metallic silver (Aureon R Gent Developer and Enhancer, applied 2 min at room temperature in the dark; Aureon). Afrer rinsing in distilled water the sections were dried. The sections were contrasted wich uranyl acerate and lead citrate. Micrographs were taken on a Zeiss EM 902 ar $80 \mathrm{kV}$. Control sections were incubared with PBS. Background staining was always negligible.

Biochenical characterization. A polyclonal anciserum was raised against human colonic mucin as described previously (anti-HCM) ${ }^{30}$. The characterization of 
the mucin epitopes recognized by 5 E9 was performed by Western- and spotblotting of purified colonic mucin, as described earlier for rat gastric mucin ${ }^{\text {in }}$. Briefly, purified mucins were either run on 4\% SDS-PAGE and blotted onto nitrocellulose or purified mucins were sported directly on nitrocellulose using a vacuum-operated spor-blot apparatus (Biorad, Richmond, USA). Blots were incubated either with anti-HCM (for reasons of comparison) or spent $5 \mathrm{E} 9$ hybridoma culture medium, diluted 1: 100, followed by incubation with goat-antirabbir $\operatorname{IgG}$ conjugated to $H R P$ and stained with DAB. Specificity for peptide and carbohydrate epitopes was tested separately as follows:

1. Proteinase $\mathrm{K}$ sensitivity prior to spor-blotting (to determine the possible pepride nature of the epirope).

2. Epitope sensitivity towards DTT reduction (to determine whether or not 5E9 detects a conformarional peptide epitope).

3. Oxidative destruction of carbohydrate epitopes by periodic acid (to determine the carbohydrate nature).

4. Incubation of 5E9 with the protease-resistent glycopeptide of HCM (as an alternative method to show reactivity towards carbohydrate-epitopes). To this end, $\mathrm{HCM}$ was digested $24 \mathrm{~h}$ with $10 \mu \mathrm{g} / \mathrm{mL}$ proteinase $\mathrm{K}$ (Mcrck) in $50 \mathrm{mM}$ Tris, $\mathrm{pH} 7.4$, at $37^{\circ} \mathrm{C}$. The proceinase $\mathrm{K}$ was inactivated by addition of an excess of phenylmethylsulfonyl fluoride (Sigma). The proteinase-resistent glycopeptide was subsequently recovered in the void volume after Sephacryl S-200 (Pharmacia) gel filtration in $50 \mathrm{mM}$ Tris, $\mathrm{pH}$ 7.5. Isolated HCM-glycopeptide was incubated for 1 h at room temperature with the antibody prior to addition to the spot-blotted mucin.

The recognition of mucin-antigens was further tested in merabolic labeling experiments of colonic biopsies followed by immunoprecipitation of radiolabeled mucins, as was described in detail elsewhere ${ }^{30}$.

To rest wherher the epitope recognized by $5 \mathrm{E} 9$ is a sialylated carbohydrate chain, neuraminidase digestion was performed according to Jass et al.". $1 \mathrm{mg}$ neuraminidase (Clostridium perfringens, Fuka 72202, Lot 326138/1) was dissolved in $0.425 \mathrm{ml}$ of $0.05 \mathrm{M}$ Tris-HCL buffer, $\mathrm{pH} 7.0$, containing $0.01 \%$ $(w / v) \mathrm{CaCl}_{2}$. Saponification was achieved by immersing the sliedes in $0.5 \%$ $\mathrm{KOH}$ in $70 \%(\mathrm{v} / \mathrm{v})$ alcohol $(30 \mathrm{~min}$ at room temperarure) Thereafter the slides were rinsed in $70 \%(\mathrm{v} / \mathrm{v})$ alcohol and washed in tap water for $10 \mathrm{~min}$. As a positive control the lectin PNA (Boehringer Mannheim) was used with and withour saponification.

Statistical analysis, Colorectal adenocarcinomas of 350 patients were entered in two multicenter prospective clinical trials between 1979 and 1981 . One rrial was designed to compare parient survival after treatment of colonic cancer by conventional surgery or the no-touch isolarion rechnique". The other trial was 
conducted to compare survival in rectal cancer parients with or without preoperanve adiotherapy. These patient series did not differ in overall survival and therefore, for the purpose of the present study, the patient groups were pooled. During the first thee years follow up took place every three months and every six monthe between three and five years after initial diagnosis and surgery. Standard protocols were conducted with routine blood counts and chemistry studies (including CEA levels) at cach wisir and liver ultrasound, ches $X$-ray and colonoscopy annually, to evaluate recurrence of disease and disease related death. After the initial five year follow-up, during subsequent years only the time and cause of death were registered. In this study, fallure was defined as death due to recurrent disease, excluding post-operarive motrality within thirty days and non-related death. The correlation between monoclonal ancibody 5E9 expression and other colorectal differentiation markers, Dukes stage, differenciarion grade, tumour size, localsation of the tumour within the large intestine, presence of (lymph-) angioinvasion or perincural invasion, lymphnode status and central lymphnode involvement was investigated in two way frequency tables using BMDP PC90 Statistical Sofware, program 4F (BMDP Statistical Sofrware, Inc. Los Angeles, CA). Interdependency of 5 E9 expression and these variables was tested with Pearsons $\chi^{2}$ method. Scoring was done by rwo independent pathologists. 5 E9 expression was compared with markers for the colorecral epithelial cell lineages. Mucin production was detected with the monoclonal antibody Parlam $3^{2 \%}$, which detects a glycoprotein present in normal goblet cells and with the High-Iron-Diamine Alcian Blue (HID-AB) rechnique, which stains sulphated mucins brown. Columnar cells were identified by immunoreactivity for secretory component (SC). Neuroendocrine differentiation was detected with a monoclonal antibody against chromogranin $\mathrm{A}$, the major component of neurosecretory granules.

As a clinicopathological staging system we used the Dukes classification'. Differcnriation grade was assessed according to criteria as outlined by Blenkinsopp?. The prognostic value of $5 E 9$ expression with respect to survival was investigated by univariate analysis, using Kaplan-Meier estimations and the stratified logrank rest, with the program 4F, BMDP PC90 Statistical Sofrware. To exclude the possibilicy of a rype lerror in the statistical analysis, in addition a Bonferroni rest was performed.

\section{Results}

Immunolistochemisty of the monoclonat antibody $5 E 9$. With the described immunization protocol, the $\operatorname{lgMK}$ monoclonal antibody $5 \mathrm{E} 9$ was obtained, staining gobler cells located at the crypr base of normal colorecral epithelium (Fig. 
1a). For immunohistochemical experiments at light microscopical level, immunostaining on standard paraffin embedded rissue with spent hybridoma supernatant was oprimal in a dilucion of $1: 50$ in PBS-1\% bovine serum albumin (BSA), after enzyme digestion of the tissue secrions with $0.01 \%$ pepsin in 0.1 mol/L HCl $\left(15 \mathrm{~min} 37^{\circ} \mathrm{C}\right)$. Comparison of unfixed cryosar secrions with paraffin sections after pepsin treatment showed an identical staining partern for both conditions. The immunoreactivity patrern of the monoclonal antibody $5 \mathrm{E}, \mathrm{in}$ normal and malignant human rissues is shown in Figures 1 and 2. Normal mucosa from neoplastic as well as non-neoplastic colectomy specimens (proximal and distal colon) was used. To exclude the possibility that 5E9 rccognizes a major blood group antigen we stained colon mucosa samples from patients with differen $\mathrm{ABO}$ blood groups. In all groups an identical staining patrern was obtained. In the digestive tract, immunoreacriviry was noted in submucosal glands of the esophagus, duct epithelium of the parotid gland, goblet cells at the lower tralf of the crypt in the duodenum, some pancrearic ducr cells (Fig. 1 b) and in the mucosa lining the gallbladder (Fig. Ic). Pancrearic islets were not stained. In normal colon mucosa, from neoplastic as well as non-neoplastic resection specimens, only crypt base cells showed 5E9 immunoreactivity. Strikingly, immunoreactiviry was observed in all goblet cells in colonic epithelium adjacent to adenocarcinomas (transitional mucosa. Fig. Id). In the stomach, reacrivity was noted only in some goblet cells in areas of intestinal meraplasia (Fig. le). In the urogeniral tracr, staining was observed in endometrial and endocervical glandular epithelium (Fig. 1f). Furthermore, reactivity was found in some acinar and duct cells of the breast. Also in prostate and bladder epithelium focal reacrivity was observed. In normal ovary tissue, no immunoreacriviry was found. In cystadenomas and adenocarcinomas of the ovary, however, whether serous or mucinous, focal immunoreacrivity was noted. In the respiratory tract, bronchial epithelium, pneumocyes rype $I I$ and few goblec cells in the lining tracheal epithelium showed staining. Carcinomas in urogenital and respiratory ract showed mostly a focal immunoreacrivity patrem.

Colorecal adenocarcinomas showed 529 immunoreacivity in $33 \%$ of our 297 cases. The proportion of posirive cases did nor differ appreciably for different periods of collection of patient material, which makes it unlikely that variarions in tissue prepararion techniques or limited antigen stabiliry mighe have influenced the immunohistochemical results. The staining was often intracellular, but also apical membrane associared; ofen some single cells were homogenously stained, but occasionally diffuse staining was observed (Fig. 2). By immunoclectron microscopy the reactiviry was located intracellular on the outcr rim of mucin vacuoles (Fig. 3). Staining of the Golgi complex was not observed. 

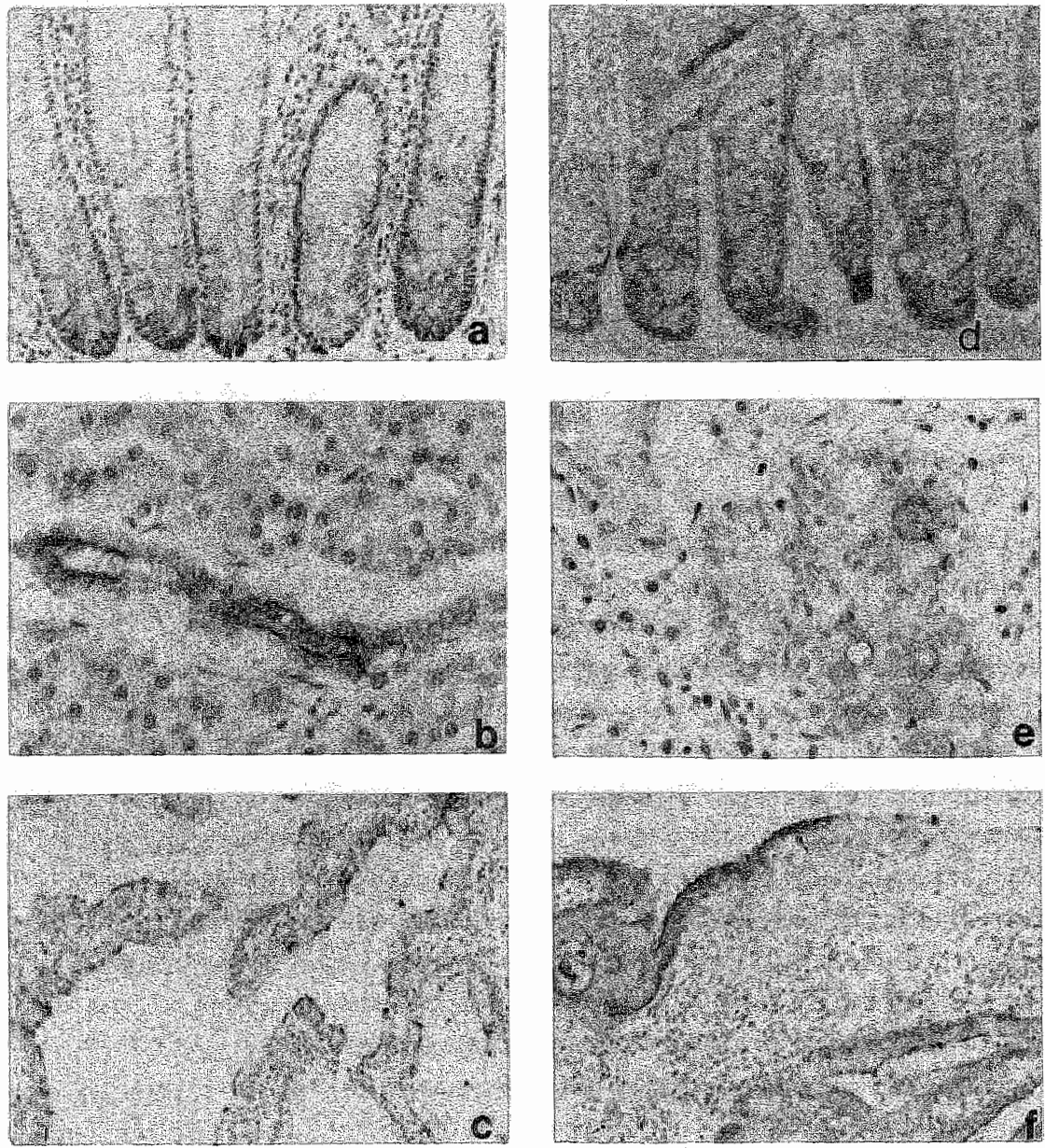

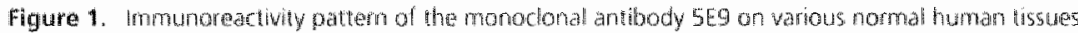

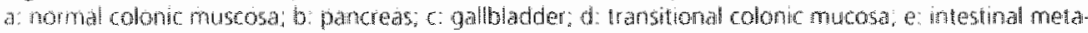
phas in the stomach: cervix uheri: squamocolunmar jutchon
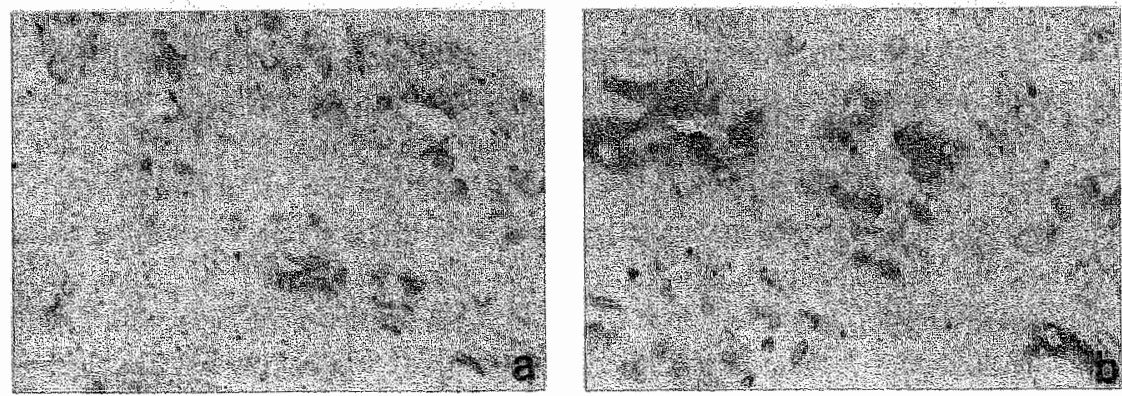

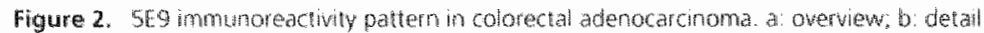



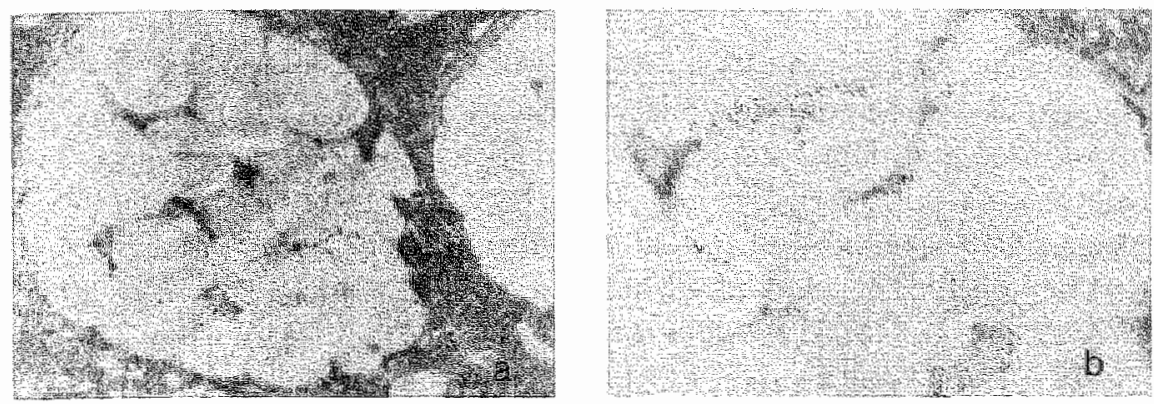

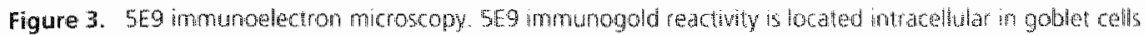
or the outer trm of much wacuoles. a: overvew; b: detal

Biochemical characterization of the $5 E 9$ eptope. As colonic mucosa was used as antigen source, mucins seemed ro be the likely candidates for the antigen recognized by $5 \mathrm{E}$. Therefore, studies were undertaken to define this antigen, using purified. HCM for comparison. Previous studies had shown that anti-HCM specifically recognizes polypeptide-epitopes of Muc ${ }^{30}$. On Western bloring, HCM was recognized by both ant-HCM and 5 E9 as a $550 \mathrm{kDa}$ band. This band was previously identified as human colonic Muc2, the major secretory mucin in the colon, which is produced in the colonic goblet cells ${ }^{31}$. Digestion with proceinase $K$ resulted in a decrease of the immunoreactivity of $5 \mathrm{E} 9$ towards HCM, while reduction by DDT had no effect. Oxidarion of carbohydrateepitopes by periodic acid resulted in complete loss of reacrivity. Aso the preincubation of $5 \mathrm{E} 9$ with the HCM-glycopepride, isolated after extensive proteinase K-digestion, inhibited the binding of $5 \mathrm{E} 9$ with spot-blotted HCM. The reactivity of and-HCM towards $\mathrm{HCM}$, which reacts primarily with pepride epitopes, showed a converse reactiwity compared to $5 \mathrm{E}$ \%: proteinase $\mathrm{K}$ destroyed all reactivity, while oxidarion by periodic acid and pre-incubation with HCMglycopeptide had no effect on reactivity. These resuls indicate that $5 \mathrm{E} 9 \mathrm{recog}-$ nizes most likely a cabohydrate-epitope of HCM. In merabolic labeling studies, using 5E9, we were unable to immunoprecipitate [ $\$$ ] sulphate-labeled mature Muc2, ot its ["SJamino acids-labeled precursor. As a positive control, immunoprecipitations from the same tissue homogenates, using anti-HCM, yielded the expected $600 \mathrm{kDa}\left[{ }^{35} 5\right.$ Jaminoacid-labeled Muc2-precursor, and the $550 \mathrm{kDa}$ [5] Sulphate-labeled mature Muc2.

5 E9 immunoreactivity could nor be abolished by neuraminidase digestron with or without prior saponification. Lecrin PNA, used as a positive control showed the expected reactiviry pattern. 
Clintropathological analysis. The 350 patients in this study were 165 men and 185 women, ranging in age from 29 to 91 years (the median age was 69 years). $5 E 9$ staining was performed on available tissue specimens of 297 parients (192 colonic adenocarcinomas and 105 rectal carcinomas). These were comparable in Dukes stage and histological grading to the overall population. To obtain subgroups suitable for statistical analysis, the subgroups were combined: group A tumours consisted of colorectal adenocarcinomas of Dukes A, B1 and B2, group $B$ consisted of the Dukes B3 while group C combined Dukes C1 and C2 tumours. Group $D$ contained the Dukes D. Of the tumours, using the above mentioned Dukes combinations, 63 were group A, 117 group B, 91 group C and 26 group $D$. The number of well differentiated cumours was $31,227 \mathrm{tu}-$ mours were moderately differentiated and 32 poorly differentiated ( 7 tumours were nor graded). $5 \mathbb{E} 9$ positive cells were found in 97 rissue specimens of colorectal cancer. Multiple two way frequency tables were prepared yielding two positive results, namely with Chromogranin $A$ and with $H I D-A B$ expression. There seems to be a trend towards a positive correlation of $5 E 9$ expression with neuroendocrine differentiation $(p=0.01)$ as well as with HID-AB, a sulfomucin stain ( $\mathrm{p}=0.04)$. Kaplan Meier survival analysis for the patient subgroups is illusrated in Fig. 4. A stratified log rank test was used, which showed nonsignificance $(p=0.265)$. If however the different Dukes groups are taken into account, $5 \mathrm{E} 9$ immunoreactivity was noted in $23,39,31$ and 11 cases in respectively group A, B, C and D. It appeared that in group B (Dukes B3) $5 E 9$ expression seems to be positively correlated with worse prognosis $(p=0.037)$. In the Bonferroni test, to exclude a type I error, this result was nor sustained.

\section{Discussion}

The histological classification of colorecral adenocarcinoma has not changed in recent years. In addition to adenocarcinomas, mucinous, signet ring and undifferentiated carcinomas are distinguished (WHO). Furthermore, grading is performed in a three grade system", which falls short in reproducibility and has limited prognostic significance. Various attempts have been made to improve classificarion using markers for enddifferentiational stages of the cell lineages in colonic epithelium ${ }^{\text {a.t.,6, }}$. Secretory component (SC) is a marker for enterocytes, lysozyme for Paneh cells, different mucin markers identify goblet cells and neuroendocrine markers neuroendocrine cells. Mucins, SC and lysozyme are often co-expressed in a large proportion of the adenocarcinomas and for these markers a consistent prognostic significance has nor been reported. With regard to neuroendocrine markers, expression of Chromogranin $A$ was repeatedly found to correlate significandly with worse prognosis ${ }^{5.6}$. 

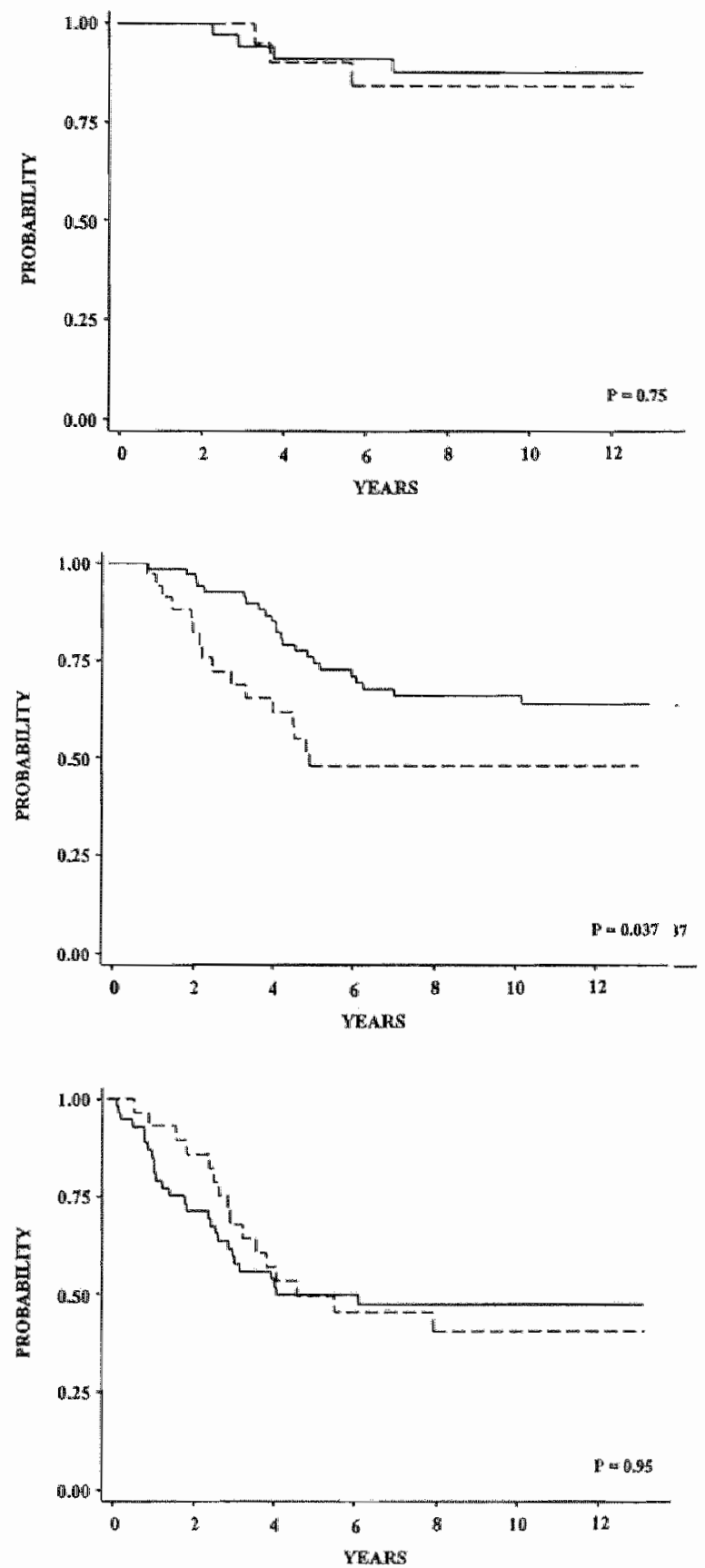

Figure 4. Kaplan Meter sumal curves for colorectal adenocarcinoma with 5 Eg immunoreactinty

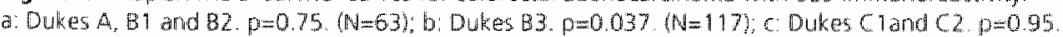
$(N=91)$; dotted lines: 5 E9 expression; solid hines. No 5 ES expression 
In looking for new markers for classificarion of colorectal cancer we reasoned that the behaviour of the eumour is largely determined by the proliferating stem cell fracion and not by teminally differenciated cells. Therefore, it would be plausible to look for markers for the undifferentiated (stem) cell fraction of the rumour. In search for such markers we reasoned that crypt base cell associated antigens might also identify immature cumour (stem) cells.

Using as an antigen source epithelium of crypt bases, which were incubated with anribodies against major mucin epitopes and with antisera aganst colonic epirhelium generated in mice to block for dom inant epitopes, we succeded in developing an antibody against a subser of goblet cells located in the lower crypt half, around and just above the proliferation zone. The epitope of this monoclonal antibody is expressed in a diversicy of human rissues, nomal and malignant, but shows a very specific staning pattern in the colon. Immunoelectron microscopy showed reactivity in the ourer rim of mucin vacuoles in goblet cells. It is of interest that in the digestive tract 5 E9 staining was found in goblet cells in inrestinal meraplasia in gastric mucosa as well as in Barrer's esophagus. Both conditions carry an increased risk for the development of adenocarcinoma. In contrast to staining of basally locared goblet cells in normal colonic mucosa, all goblet cells were stained in transitional mucosa neighboring adenocarcinoma. Ulerastructural studies have indicated that crypt epithelial cells in transitional mucosa show slower maturation than normal ${ }^{\text {t }}$. The increase of $5 \mathrm{E} 9$ positive cells in ransitional mucosa could be the result of such a delay in the process of crypt cell macuration and this observation would be in keeping with the lower differentiation level of 5 E9 expressing goblet cetls.

In search for the epitope recognized by $5 \mathrm{E} 9$, immunobloting showed that $5 \mathrm{E}$ ? recognizes an epitope present on an HCM associated glycoprotein, identified as human colonic Muc2 $2^{\text {sin }}$. The blocking of 5 E9 staining by periodic acid oxidation and by preincubarion with the HCM-glycopepride indicates that 5 E9 recognizcs a cabohydrate (O-glycans) epitope on Muc2. Alhough the monoclonal antibody recognized Muc2 in blots, it was not able to recrieve the antigen by immunoprecipitation from homogenates. Possible explanarions could be scarciry of the O-glycan epirope, the absence of an $\mathrm{O}$-glycan in Muc2 ${ }^{35}$ or low affiniry of $5 \mathrm{Eg}$, which is not entrely unlikely given the $\operatorname{IgM}$ isotype of the antibody. 5 E) stained specifically the mucin granules in goblet cells low in the colonic and small intestinal crypts of all individuals tested, indicaring that the carbohydrate epitope was not a blood-group annigen nor an antigen covered by blood-group saccharides. The crype base specificity of 589 staining suggests that the Muc2 cpitope, recognized by $5 \mathrm{E} 9$, becomes masked when the goblet cells differentiate further during their migracion upward from the botrom of the crypt. This could imply that the O-glycosylarion-pattern of Muc2 changes when the crypt cells 
migrate upward. The epitope recognized by $5 E 9$ seems not to be sialic acid given the insensitivity to neuraminidase treatment with or withour prior saponification. In the literature other monoclonal antibodies like SIMA and ST ${ }^{3}$ with a comparable immunoreacrivity pattern are described. These anvibodies recognize sialylated carbohydrate chains.

To evaluate the potential prognostic significance of $5 \mathrm{E} 9$ expression in colorecral adenocarcinomas, we stained a series of human colorecral carcinomas and compared the 5E9 status with various earlier studied pathological variables. We nored a trend rowards 5 E9 expression along with Chromogranin A defined neuroendocrine and $\mathrm{HID}-\mathrm{AB}$ defined sulphomucin expression. Borh characteristics were earlier found to be associated with worse prognosis ${ }^{5}$. The stratified logrank test did not yield any significance. In our group A (Dukes A1, BI and B2) and group C carcinomas (Dukes C1 and C2), 5E9 staining did not have any prognoscic significance. In Dukes B3 patients however, a group of patients with a heterogeneous chance of survival, $5 E 9$ appeared to be a positive prognosric variable, identifying a subgroup of patients with a worse prognosis. This enhanced expression of the 5E9 epitope in prognosrically unfavourable Dukes B3 adenocarcinomas can indicate that a change in the O-glycosylation of Muc2 in colonic tumour cells might take place during progression cowards recurrent (incurable) disease.

In conclusion, we have developed a new monoclonal antibody which most likely recognizes a non-terminal carbohydrate epitope on the Muc2 O-glycans in the collon and which reacts specifically with crypr base cells in colonic mucosa. In group B. Dukes B3 adenocarcinomas, 5 E9 staining identifies a subset of rumours with a tendency for worse prognosis. Sudies on more cases are needed to show whether these results prove to be starisrically significant. Also the clinical value of $5 \mathrm{E} 9$ for colorecral cancer classification needs to be further evaluated.

\section{References}

\section{Dukes CE.}

The classification of cancer of the rectum.

J Pathol Bacterial 1932;35:323-332.

2. Blenkinsopp WK, Stewart-Browns, Blesowsky L, Kearny G, Fielding LP. Histopathology reporting in large bowei cancer. I Clin Pathol $1981 ; 34: 598-613$.

3. Ho SB, Itzkowitz SH, Friera AM, Jiang SH, Kim YS.

Cell lineage markers in premalignant and malignant colonic mucosa. Gastroenterology 1989:97:392-404 
4. Arends M, Wiggers T, Verstijnen K, Bosman FT

The occurence and clinicopathological significance of serotonin immunoreactive cells in large bowel carcinoma.

I Pathol 1986;149:97-102.

5. De Bruine AP, Wiggers $T$, Beek $C$ valovics $A$, von Meyenteldt $M$, Arends $J W$. Bosman FT.

Endocrine cells in colorectal adenocarcinomas: Incidence, hormone profile and prognostic relevance.

int J Cancer 1993;54:765-771.

6. Hamada Y, Orshi A, Shoji T, Takada H, Yamamura M. Hiokik Yamamoto M. Endocrine cells and prognosis in patients with coiorectal carcinoma. Cancer $1992 ; 69: 2641-2646$

7. Chang WM, Leblond CP.

An unitarian theory of the origin of the three populations of epithelial cells in the mouse large intestine.

Anat Rec 1971;169:293.

8. Griffiths DFR, Davies S:, Willams GT, Williams ED.

Demonstration of somatic mutation and colonic crypt clonality by $X$-linked enzyme histochemistry.

Nature 1988;333:461-463.

9. Kirkland SC.

Clonal origin of columnar, mucous, and endocrine cell lineages in human colorectal epithelium.

Cancer 1988;61:1359-1363.

10. Damjanow 1 , Amenta P, Bosman FT.

Undifferentiated carcinoma of the colon containing exocrine, neuroendocrine and squamous cells.

Virch Arch Pathol Anat 1983:401:57-66.

11. Novello P. Duvillard P. Grandjouan 5. Elas d, Rougier P. Bognel C Prade M Carcinomas of the colon with multidirectional differentiation.

Dig Dis 50 i $1995 ; 40: 100 \cdot 106$

12. Mever IS, Rao BS, Stevens SC, White WI

Low incidence of estragen receptor in breast carcinomas with rapid rates of cellular replication.

Cancer 1979:40:2290-2298. 
13. Turowski GA, Rashid Z, Hong F. Madri 1A, Basson MD.

Gutamine modulates phenotype and stimulaties prolferation in human colon cancer cell lines.

Cancer Res 1994:54:5974-5980.

14. Sakamoto K. Venkatraman G, Shamsuddin AM.

Growth inhibition and differentiation of HT-29 cells in vitro by inositol hexaphosphate (phytic acid).

Carcinogenesis 1993:14:1815-1819.

15. Zhao $x$, Feldman $D$.

Regulation of vitamin D receptor abundance and responsiveness during differentiation of HT-29 human colon cancer cells.

Endocrinology 1993;132:1808-1814

16. Baghdiguian 5, Verrier B, Gerard C. Fantini gentemen.

Insulin like growth factor I is an autocrine regulator of human colon cancer cell differentiation and growth.

Cancer Lett 1992;62:23-33

17. Mackillop W), Stewart SS, Buick through.

Density/volume analysis in the study of cellular heterogeneity in human ovarian carcinoma.

Brit I Cancer 1982:45:812-820.

18. Bizzari fP. Mackillop WJ, Buick RN.

Cellular specificity of NB70K, a putative human ovarian antigen.

Cancer Res 1983;43:864-867.

19. Itzkowitz SH, Shi ZR, Kim YS.

Heterogeneous expression of two oncodevelopmental antigens, CEA and SSEA- 1, in colorectal cancer.

Histochem \1986;18:155-163.

20. Brattion MG, Levine AE, Chakrabarty S, Yeoman LC. Heterogeneity of human colon carcinoma.

Cancer Metastasis Rev 1984;3:177-191.

21. Salmon SE.

Humain tumor colony assay and chemosensitivity testing.

Cancer Treatment Rep 1984;68:117-125. 
22. Ten Kate 1, Verspager $H$, Whinen J, Meremet $M$, wh Ingh $H$, Bosman $T$, Meera Khan P.

Maturation dependent changes in nucleoside phosphorylase (NP) adenosine deamnase (ADA) and ADA complexing proten (ADCP) in intestiral epithelial cells.

In: Peeters H, ed. Proceedings of the $32^{\text {Colloquim }}$ Crotides of the Biological Fluids. Oxford: Pergamon Press, 1985: 339-342.

23. Whitehead $R H$, Brown $A_{r}$ Bhatal PS.

A method for the isolation and culture of human colonic erypts in collagen gels.

In Vitro Cell and Developm Biol 1987:23:436-442

24. King SW, Morrow Kl.

Monoclonal antibodies produced against antigenic determinants present in complex mixures of proteins.

Biotechniques $1988 ; 6: 856-861$

25. Verstinen CPHI, Arends MW, Moerkerk PTM, Plils M, Kuypers-Engelen B. Bosman FT.

Colonic epthelium reactive monoclonal antibodies. Identification and immunohistochemical localization of the target epitopes.

Histochemistry 1989;92:397-406.

26. Köhler G, Mistein C.

Continuous cultures of fused celis secreting antibodies of predefined specificity. Nature 1975:256:495-497.

27. Dinjens WMM, vd Linden EPM, Signet C, Winen J, Meera Khan P. Ten Kate J, Bosman FT.

Solid-phase adsorption of antigens for efficient production of antibodies reactive with native and fixed tissue antigens.

Jimmunol Meth 1990;126:175-182.

28. Van der Kwast TH, Versnel MA, Delahaye M, De Jong A, Zondervan PE, Hoogsteden $H$.

Expression of epithelial membrane antigen on malignant mesothelioma cells: an immunocytochemical and immunoelectron microscopic study.

Acta Cytologica 1988;32:169-174. TH.

29. Zondenan PE, De Jong A, Sorber CW, Kok LP. De Bruyn WC, wan der Kwast Microwave stimulated incubation in immunoelectron microscopy: a quantitative study.

Histochem / 1988:20:359-364. 
30. Tytgat KMAl, Büller HA, Opdam FM, Km YS, Enemand AWC, Dekker germ themen.

Biosynthesis of human colonic mucin: Muc2 is the prominent secretory much.

Gastroenterology 1994:107:1352-1363.

31. Dekker J, Van Beurden-Lamers WMO, Strous G]

Blosynthesis of rat gastric mucin.

J Biol Chem 1989:264:10431-10437.

32. Jass JR, Allison U, Edgar $5 G$.

Distribution of sialosyl Th and Tn antigens within nomal and malignant colorectal epithelium.

J of Pathol 1995; 176:143-149.

33. Wiggers T, seekel J. Arends JW, Brinkhorst AP, Khok HM. Luyk Cl, Munting JOK, Povel JACM, Rutten APM, Volovics A, Greep $J M$.

Nowtouch isolation technique in colon cancer: a controlled prospective trial.

Br J Surg $1988: 75: 409-415$.

34. Riddel RH. Lewin B.

Ultrastructure of the transitional mucosa adjacent to large bowel carcinoma.

Cancer 1977; 40:2509-2522.

35. Dekker 1. Strous GJ.

Covalent oligomerization of rat gastric mucin occurs in the rough endoplasmatic re. ticulum, is N-glycosylation-dependent, and precedes initial O-glycosylation.

J Biol Chem 1990;30:18116-18122.

36. Pibrow SI, Hertzog PJ, Pinczower GD, Limnane AW.

Expression of a novel family of epitopes on small intestinal mucins in colorectall cancers, adjacent and remote mucosa.

Tumor Biol 1992:13:251-267.

\section{Acknowledgement}

Winand N.M. Dinjens and Fred T. Bosman were supported by grant EUR-90-53 from the Durch Cancer Sociery.

The skilfull contribution of $A$. de Jang in the immunoelectron microscopy experiments is gratefully acknowledged.

Thanks are due to Adriaan P. de Bruine for fruirfull discussions and to Hans A.). Bruinsma for additional immunohistochemisury. 

Chapter 4

\section{L-CAM expression in normal, premalignant and malignant colon mucosa}

Anna A.M. v.d. Wurff, Joop ten Kate, Edith P.M.

v.d. Linden, Winand N.M. Dinjens, Jan-Willem

Arends, Fred T. Bosman.

I Patho 1992:168:281-286 


\section{Introduction}

The cell adhesion molecule L-CAM, also known as E-Cadherin, Uvomontin, Arc-1 or cell CAM $120-80$, plays an important role in cell-cell interactions. Damsky et al. were the first to identify L-CAM in humans. L-CAM plays an essential role in embryonic development and morphogenesis, as well as in the maintenance of the normal structure and fumction of adult tissues by way of calcium dependent homophilic adhesion between epithelial cells?

Shimoyama et al. ${ }^{3}$ and Eidelman et al. already reported that 1 -CAM expression can be found in all normal human adult epithelia. Shimoyama et al. " described L-CAM reactivity at the intercellular border only, while Eidelman et al. found a uniform expression of I-CAM along the entire cellular circumference in squamous epithelia of the skin , but in intestinal epichelium expression only along the zonula adherens. L.CAM reactivity was not found at the basal plane of the cell membrane facing the basement membrane. Studies on L-CAM expression in cancer thave mainly focused on tumour cell lines. These studies have shown that transient down regulation induces invasive behaviour of tumour cells in parallel with loss of junctional complex formation. Vleminckx et al." described how epirhelial tumour cells, highly invasive in the embryonic chicken heart assay, lost their invasive potential after transfection with a CDNA encoding for L.CAM, and also did not invade into type I collagen matrices. These data indicate that L-CAM expression and invasive behawiour are inversely correlated. Therefore, L-CAM could be a marker in histoparhology to discriminate between carcinomas with metastaric and those without metastatic porential. Earlier reports ${ }^{3,6.7}$ described L-CAM expression in a series of human tumours. These indicate that all adenomas and well differenciated adenocarcinomas express L-CAM in a pattern comparable with that in the corresponding normal tissues. In contrast, poorly differentiated carcinomas showed a weaker and heterogencous expression pattern with L-CAM evenly distributed along the entire cell circumference. Shimoyama and Hirohashi" reported L-CAM reactivity on the cell surface in gastric carcinomas of the scattered type i.e. those cancer cells that did not show right intercellular adhesion.

We hypothesined that in wiew of the possible role of L-CAM as an invasion suppressor, L-CAM immunoreactivity would be detected in colonic adenomas, but in not carcinomas.

The present study was performed to test this thypothesis by analyzing $\mathbb{L}$ CAM expression in tissue specimens of normal mucosa, adenomals and carcinomas of the colon. 


\section{Materials and methods}

Surgical specimens of 23 colorectal polyps (17 tubular and 3 tubulovillous adenomas and 3 hyperplastic polyps), 38 adenocarcinomas (16 Dukes A/B and 22 Dukes C) were obtained. Normal mucosa was excised from 20 colectomy specimens at a site at least $5 \mathrm{~cm}$ from the neoplasm. Tissues were snap frozen in isopentane and stored ar $-70^{\circ} \mathrm{C}$ uncil sectioning. Sections of $4 \mu \mathrm{m}$ thickness were cur, air dried, fixed in methanol for 1 minute at $-20^{\circ} \mathrm{C}$, dipped in acetone at $-20^{\circ} \mathrm{C}$ and stained. To reduce non specific staining, endogeneous peroxichase was inactivated $\left(0,5 \% \mathrm{H}_{2} \mathrm{O}\right.$ in methanol). An indirect immunoperoxidase method was used. Briefly, the sections were incubated with a monoclonal anti L-CAM antibody (6F9, Eurodiagnostics, the Netherlands) in a dilurion of $1: 80$ in PBS-1\% BSA (1 h. RT) and after three washings in PBS incubated with a rabbit anti mouse $\mathrm{Ig}$-HRP conjugate (Dakoparts Denmark)(1 h. RT). After repeated washing in PBS, HRP activity was visualized with diaminobenzidine (DAB) and $\mathrm{H}_{2} \mathrm{O}_{z}$. Finally the sections were counterstained with haematoxylin and mounted with entellan. In control slides PBS-10\% BSA was used wirhour the monoclonal antibody,

For photography representarive sections were stained using an immunofluoresence method. Sections were incubated with L-CAM as described abowe, bur after three washings in PBS they were incubated with fuorescein isothiocyanate (FITC) conjugated rabbit anti mouse Fab fragments (Dakopatts Denmark) diluted 1:50 (1 h. RT). They were rinsed in PBS, mounted in Immunomount (Shandon Pittsburgh) and examined with a Leitz Dialux 20 microscope equipped for UV-epi-illumination.

Scoring was performed by two independent observers. The following nomenclarure was used: (1) Normal i.e. the same partern of L-CAM immunoreacrivity as seen in normal colon mucosa: uniform expression along the intercellular borders. (2) Apical i.e. intensified immunoreactivicy at the luminal cell surface and (3) negative: no immunoreactivity at all.

To differentiate between extractable and non-extractable L...CAM, we used at protocol based on the observation "that some L-CAM molecules might not be functionally linked with the cytoskeleton and therefore can casily be solubilized with Triton X-100. To this end, rissue sections were prencubated before and after fxarion procedures as described, for different time periods ( $\left.1 \mathrm{sec}^{1}\right)$ min, 5 min, $15 \mathrm{~min}, 30 \mathrm{~min})$ with various concentrations of Triton $X-100(0,05 \%$ $0,1 \%, 1 \%$ ). As a control (for reduction of non specific background) tissue seccions were preincubated with $0,5 \mathrm{M} \mathrm{NaCl}$ instead of Triton X-100. L-CAM staining was subsequently performed as described. 


\section{Results}

Normal colonic epithelium. All normal mucosa specimens showed discinct nonpolarized evenly distributed expression of L-CAM. Immunoreactivity was found. along intercellular borders and not at the basal plane of the cell facing the basement membrane. (Fig. 1)

Colon polyps. The findings are summarized in Table $\mathbb{I}$.

All 3 hyperplastic polyps studied displayed a staining partern identical to that seen in normal mucosa. The 20 rubular and tubulovillous adenomas all demonstrated a normal staining pattern, four of which with intensified L-CAM expression at the apical. cell surface. However, the staining was less than in normal mucosa.

Dukes $A / B$ carcinomas. 15 out of 16 Dukes $A / B$ carcinomas showed normal though weak L-CAM expression, six with apical L-CAM immunoreactivity (Fig. 2). One poorly differentiated carcinoma appeared to be negative.

Dukes C carcinomas. 19 out of 22 Dukes C carcinomas showed a normal though weak L-CAM expression, including eight carcinomas (six moderately differentiated and two poorly differentiared) with L-CAM immunoreactivity at the apical cell surface.

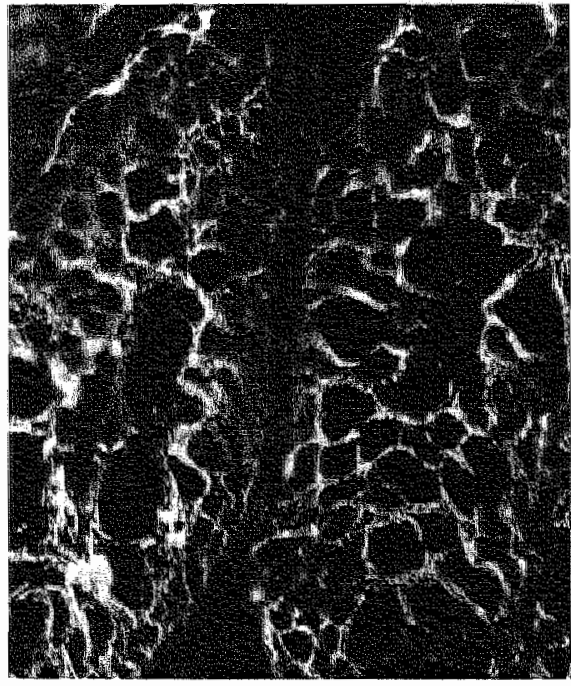

Figure 1. Wornai L.CAM staning pattern in nomal colon mucosal using an indired mumofuorescence method with monocional ant $L$ - CAN antibody $6 F 9$.

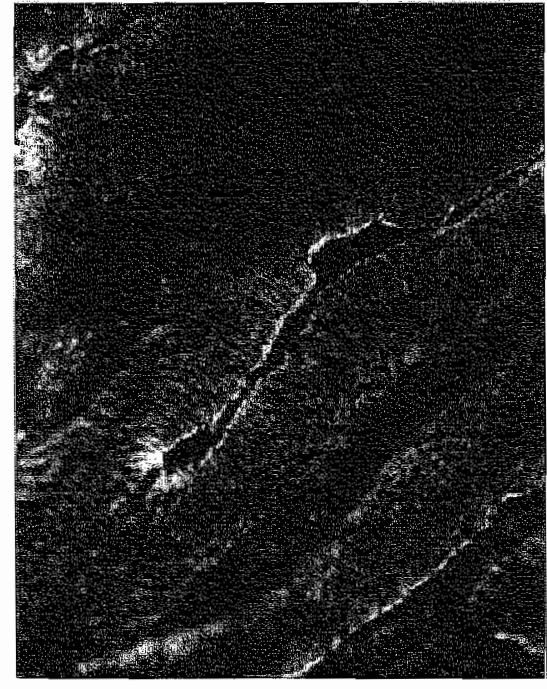

Figure 2. Apicai L-CAM staing patem in colon neoplasm using an indired immunofluorescence method with monodomal anti-L-CAM antibody 6 F9. 
Table L.

Adenomas

\section{LCAM expression}

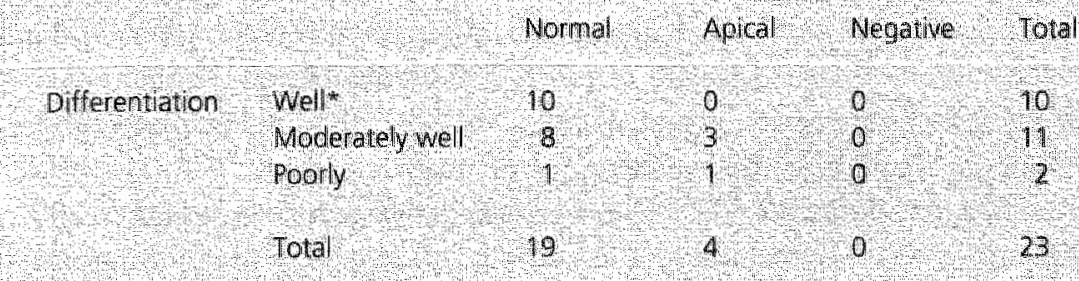

* ind uding three hyperplastic polyps

Dukes AlB

\section{LCaM expression}

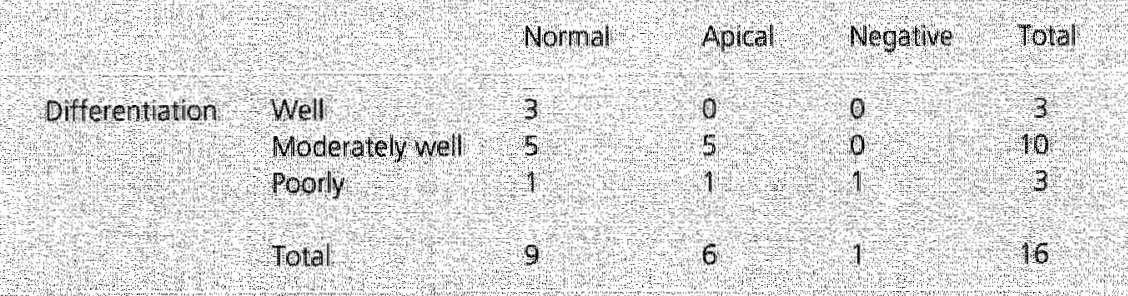

Dukese

L-CAM expression

\begin{tabular}{|c|c|c|c|c|c|}
\hline & & Nomblal & Apital & Negative & Total \\
\hline Difterentiation & Well & 4 & 0 & 10 & 4 \\
\hline & Moderately well & 6 & 6 & 0 & 12 \\
\hline & Pooly & 1 & 2 & 3 & 6 \\
\hline & Tota: & 11 & 8 & 3 & 22 \\
\hline
\end{tabular}


In three poorly differentiated carcinomas no L-CAM expression was found. In none of the neoplastic tissue specimens any difference in L-CAM reactivity according to area within the tumour (centre or periphery) could be found. L-CAM expression after Triton X-100 pretreatment. All three colon rumours with apical staining partern showed strongly reduced or negative L-CAM immunoreacrivity after preincubation $(1 \mathrm{sec}$ ) with $0,05 \%$ Triton $X-100$. The two tumour specimens wich a normal staining pattern i.e. along intercellular borders, did not loose their L-CAM reacrivity after Triton X-100 preincubation. Longer preincubation with higher concentrations Triton $X-100$ resulted in loss of morphology which made scoring impossible.

Control preincubation with $0,5 \mathrm{M} \mathrm{NaCl}$ or preincubation with Triton X-100 after fixarion of the sections did nor alter the apical nor the normal immunoreactivity.

\section{Discussion}

In the process of invasive growth, in which one of the critical steps is the detachment of epithelial junctions, L-CAM may play an important role. In studies on tumour cell lines" ${ }^{9}$, a very clear correlation between L-CAM expression and invasive behaviour is described. On the one hand, cells expressing L-CAM do not infiltrate into collagen matrices or chicken heart fragments. After incubation with monodonal antibodies against L-CAM, however, they show invasive behaviour". On the other hand, cells that do not express L-CAM have been shown to display invasive behaviour, but after transfection with a cDNA encoding for L-CAM', they convert into non invasive cells. It appears, therefore, that L-CAM functions as an invasion suppressor. These studies indicate that L-CAM expression must be down regulared once a cell becomes invasive.

It is interesting to nore that a recessive oncogene, the DCC gene ${ }^{12}$, shows homology with a member of the CAM gene family, namely N-CAM. This DCC gene is deleted in more than $70 \%$ of colon carcinomas. The delerion was regarded as a relatively late event during tumour progression. This does not parallel our observations in relation to the early down regulation of L-CAM.

Eidelman et al. ${ }^{4}$ describe L-CAM immunoreactivity in more than sixty human normal tissues and tumours, including mine adenomas and five carcinomas of the colon. They concluded that nomal colon epirhelium shows polarized L-CAM expression and that in tumours L-CAM expression is less polarized, weaker and more hererogeneous. Other authors ${ }^{36,7}$ concluded that L-CAM reactivity in carcinomas is less intense and more heterogeneous than in normal tissue. Shimoyama and Hirohashi reported that 19 out of 54 gastric carcinomas expressed L-CAM on the surface of the cancer cells of scartered type carcinomas 
and they postulated that defective expression of intrinsic factors, which anchor L-CAM to the cytoskeleton, are resposible for the aberrant expression of L-CAM, which by immunoblotting had a normal size.

Our studies confirm that in normal colon epithelium L-CAM is evenly distribured along cell-cell borders. A periluminal accentuation of reacrivity (polarization) on the lateral sites of the apical cell pole, as described by Eidelman er al." was also observed, but not in normal rissue. Confirming the observations of other workers $^{3.63}$, we found weaker and more hererogeneous immunoreacrivity in carcinomas, without differences between metastasizing and non metastasizing carcinomas. L-CAM down regulation appeared to be an early and a gradual process in colon carcinogenesis, because it occurred in adenomas and was most striking in high grade carcinomas, where L-CAM expression was absent. We found that a number of adenomas and carcinomas showed in addition to a normal though weaker staining pattern also staining at the apical cell borders. This staining partern could be abolished by preincubarion in Triton X-100 but not by preincubation with $0,5 \mathrm{M} \mathrm{NaCl}$. Following the suggestion by Nelson et al ${ }^{8}{ }^{8}$ we hypothesize that apical L-CAM is not linked to the cytoskeleton and therefore is more easily extractable with a detergent. This is in concordance with the suggestions made by Shimoyama and Hirohashi' concerning L-CAM expression in scattered type gastric carcinomas.

Although four poorly differentiated carcinomas were totally devoid of L-CAM reactivity, we rhink that the number of cases we studied is too small to draw any conclusions regarding L-CAM down regularion and differentiation. Shimoyama and Hirohashi ${ }^{13}$ reported one aggressive hepatocellular carcinoma which was L-CAM negative.

In this study we demonstrated that L-CAM down regulation occurs in all colon adenomas and carcinomas, irrespecrive of stage of progression or localisation within the tumour, although there is a trend towards decreasing L-CAM expression along with decreasing grade of differentiation. A distinction between invasive and non invasive tumours cannor be made on the basis of L-CAM expression.

Studies at the single cell level might indicate that L-CAM down regulation is a temporary event, occurring only at the moment of invasive activity. Studies are now in progress to determine the validity of this concept. 


\section{References}

7. Damsky H, Richa 1, Solter D, Knudsen K. Buck A.

Identification and purification of a cell surtace glycoprotein mediating intercelular adhesion in embryonic and adult tissue.

Cell $1983,34: 455-466$

\section{Takeichi M.}

Cadherin cell adhesion receptors as a morphogenetic regulator.

science 1991, 251:1451-1455

3. Shimoyama $Y$, Hirohashis, Hirano S, et al.

Cadherin cell adhesion molecules in human epithelial tissues and carcinomas.

Cancer Res 1989, 49:2128-2133

4. Eidelman 5, Damsky CH. Wheelock J, Damianow I.

Expression of the cell-cell adhesion glycoprotein cell-CAM 120/80 in normal human iissues and tumors.

Am IPathol 1989,135:101-110

5. Veminckx K, Vakaet Jr. L. Mareel M. Fiers W Van Roy F.

Genetic manipulation of E-Cadherin expression by epithelial tumor cells reveals an invasion suppressor role.

Gell 1991, 66:107-119

6. Shiozaki H, Tahara H, Oka H, et al.

Expression of immunoreactive E-Cadherin adhesion molecules in human cancers.

Am J Pathol 1991, 139:17-23

7. Shimoyama $Y$, Hirohashi sincerely.

Expression of Ex and P-Cadherin in gastric carcinomas.

Cancer Res 1991, 51:2185-2192

8. Nelson W. Shore EM. Wang AZ, Hammerton RW.

Identification of a membrane-cytoskeletal complex containing the cell adhesion molecule Uvomorulin (E-Cadherin). Ankyrin, and Fodrin in Madin-Darby Canine Kidney epithelial cells.

1) Cell Biol 1990, 110:349-35?

9. Mareel $M$, Weminckx $K$, Vermeulen 5 , et al. Homotypic cell-cell adhesion molecules and tumor invasion.

Prog Histochem Cytochem 1992, 26: 95-106

10. Frixen UH, Behrens J Sachs $M$, et al.

$E$-Cadherin mediated cell-cell adhesion prevents invasiveness of human carcinoma cells.

J. Cell Biol 1991, "13:173-185 
11. Behrens $\int$, Mareel MM, Van Roy FM, Birchmeier W.

Dissecting tumor cell invasion: epithelial cells acquire inwasive properties after the loss of Uvomorulin mediated cell cell adhesion.

J Cell Biol 1989, 108: 2435-2447

12. Fearon ER, Cho KR, Nigro $\mathrm{IM}$, et al.

identification of a chromosome $18 \mathrm{q}$ gene that is altered in colorectal cancers.

Science $1990,247: 49-56$

13. Shimoyama $Y$, Hirohashi sincerely.

Cadherin intercellular adhesion molecule in hepatocellular carcinomas: loss of $\mathbb{E}$ Cadherin expression in an undifferentiated carcinoma.

Cancer Lett 199:, 57: 131-135 

Chapter 5

\section{L-CAM expression in lymph node and liver metastases of colorectal carcinomas}

Anna A. M. van der Wurf, Jan-Willem Arends, Edith P. M. van der Linden, Joop ten Kate, Fred T. Bosman.

J Pathol 1994:172:177-182 


\section{Introduction}

The cell adhesion molecule L-CAM, also known as E-cadherin, uvomorulin, Arc-1 or cell CAM 120-80, is a member of the CAM gene family, which plays an important role in epithelial cell-cell interaction'. In the process of invasion, loss of intercellular adhesion is one of the early occurring critical steps towards metastasis. Srudies on various human and non-human tumour cell lines have revealed an inverse correlation beween L-CAM expression and invasive growth. Vleminckx er al." described highly invasive epithelial tumour cells which after transfection with a CDNA encoding for L-CAM, lost their invasive potential. L-CAM expression in normal and cancerous human rissues was described in several reports ${ }^{3 . y}$. These revealed L-CAM immunoreactivity in normal human epithelia on the plasma membrane along intercellular borders. Well differenciated carcinomas generally show an L-CAM immunoreacrivity pattern comparable to normal rissue, whereas in poorly differentiated carcinomas mostly weak and hererogeneous staining is found. In our previous study on L-CAM expression in colonic carcinomas" we also noticed a trend towards decreasing L-CAM expression along with decreasing differentiation. In addition, some adenomas and carcinomas showed apical instead of intercellular staining, suggesting nonfunctional localization of L-CAM". Our observations indicated, however that invasive and non-invasive tumours cannor be distinguished on the basis of L.-CAM expression.

Extrapolating from the data obcained in in virro studies on cultured cell lines, which have demonstrated loss of cell adhesion molecules in association with invasiveness $^{12.3,1,1,15}$, one would expect to find reduced L-CAM immunoreactivity in metastases.

To test this hypothesis we analyzed L-CAM immunoreactivity patterns in lymph node and liver metastases originating from colorectal cancer.

\section{Material and methods}

Surgical specimens of 12 liver merastases and 10 lymph node metastases were obtained, snap-frozen in isopentane and stored at $-70^{\circ} \mathrm{C}$ until sectioning. Sections of $4 \mu \mathrm{m}$ thickness were cut, air dried, fixed in methanol for $1 \mathrm{~min}$ at $-20^{\circ} \mathrm{C}$, dipped in acetone at $-20^{\circ} \mathrm{C}$ and stained. To reduce non-specific staining endogeneous peroxidase was inactivated with $0.5 \% \mathrm{H}_{2} \mathrm{O}_{2}$ in PBS. An indirect immunoperoxidase method was used. Sections were incubated overnight with a monoclonal anti-L-CAM antibody 6 F9 (Eurodiagnostica, The Netherlands) in a dilution of 1:40 in PBS- $1 \%$ BSA at $4^{\circ} \mathrm{C}$. The production, specificity and immunohistochemical use of this antibody has been extensively reported by Frixen 
et al. ${ }^{13}$. After three washes in PBS, sections were incubated with a rabbit antimouse Ig-HRP conjugate (Dakopatts, Denmark) for $1 \mathrm{~h}$ at room temperature. After repeated washing in PBS, peroxydase activity was visualized with diaminobenzidine (DAB) and $\mathrm{H}_{2} \mathrm{O}_{2}$. Finally, the sections were counterstained with haematoxylin and mounted with entellan. As a positive control sections of normal colonic mucosa were used. In this marerial an intercellular plasma membrane associated pattern of immunoreactivity was consistently shown in colonic mucosal. epithelium. As a negative control for each and every section a separate slide was incubated with PBS-1\% BSA without the monodonal antibody or with an irrelevant monoclonal antibody. In these sections consistently no staining was observed.

For microphotography, representarive sections wete stained using an immunofuorescence method. Sections were incubated with anti-L-CAM antibodies as described above, but after three washes in PBS, they were incubated with biorinylated sheep anti mouse Fab fragments (Amersham, United Kingdom) diluted 1:250 (30 min, room temperature). After repeated washing in PBS, sections were incubated with fluorescein conjugated streptavidin (Dakopatss, Denmark) diluted 1:100 ( $1 \mathrm{~h}$, room temperature). They were rinsed in PBS, mounted in Immunomount (Shandon, Pittsburgh) and examined with a Biorad MRC 600 Confocal Scanning Laser Microscope, equipped with a mixed Argon/Krypton gas laser. FlTC fluorescence was excited with the $488 \mathrm{~nm}$ laser line and recorded using a $515 \mathrm{lp}$ band pass filter. The immunofluorescence and immunoperoxidase results were invariably concordant.

Scoring was done by two independent observers (AvdWW and JWA). The following nomenclature was used: (1) normal, i.e., a pattern of L-CAM immunoreaccivity corresponding with that in normal colon mucosa, which consists of uniform expression along the intercellular borders; (2) apical, i.e., intensified immunoreacrivity at the luminal cell surface without intercellular staining pattern; and (3) negarive: no immunoreactivity at all.

\section{Results}

All lymph node metastases showed L-CAM immunoreactivity, one of them in a predominantly apical, nine in an intercellular pattern. From three tumours we collected two lymph node metastases each (I and II, Table I). In two lymph node pairs the L-CAM staining partern was identical, in the other pair one lymph node metastasis showed poor differentiation and reduced L-CAM staining with negarive areas amounting to thircy percent of the section. No totally negative lymph node metastases were seen. Heterogeneity existed in all lymph node metastases with intercellular staining, apical staining and negative areas in 


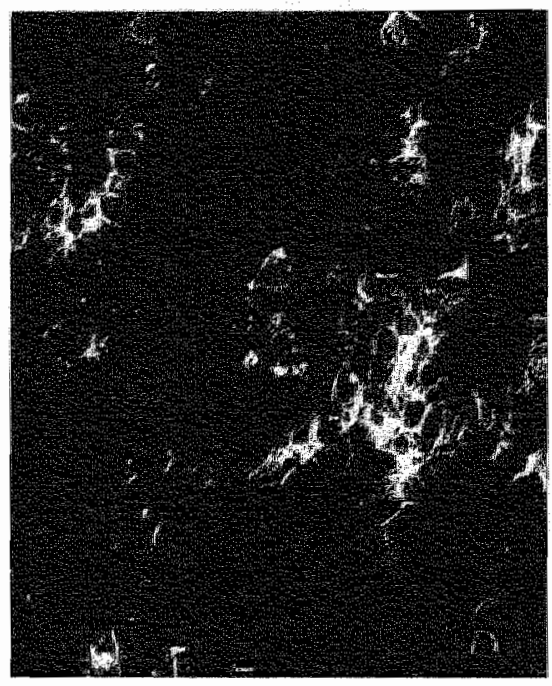

Figure 1. Intercellutar and party negariwe L.CAM staining pattem in lymph nade medastasts of colorectal carcinoma using an immunoluorescence method with monoctonal anti-L CAM antibody GF9.

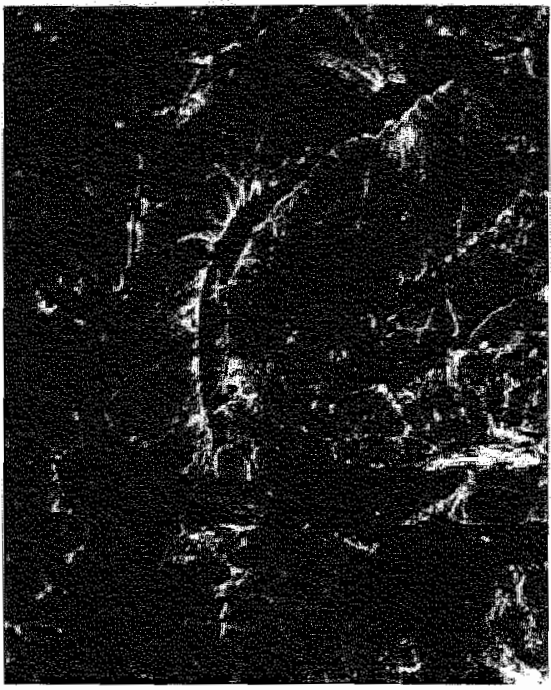

Figure 2. Predominantly apical L-CAM staining pattern in liver metastasis of cotorectal carchoma using an immunofluorescence method with monodiona: anti-h-CAM antibody $6 F 9$.

variable admixures. Almost all metastases (Fig. 1) showed areas in which an apical as well as an intercellular staining partern occured (Normal/Apical combined; Table I). Both patterns occurred at random, regardless of local growth partern or differentiarion grade. In three lymph node metastases negative areas accounted for a higher percentage surface area than in the primary rumour. All corresponding primary tumours showed a predominantly normal intercellular L-CAM sraining partern (Table 1), with slight heterogeneity in immunoreacrivity patterns. Table $I$ also shows the grade of differentiation of the primary tumotn. In comparison with the primary tumours the L-CAM staining pattern in lymph node metastases seemed to be somewhat more heterogeneous.

In all liver metastases L.CAM immunoreactivity was demonstrated, in five in a predominantly normal, and in seven in an apical pattern (Table II; Fig. 2). Unfortunately, primary tumours were not available for comparison. No L-CAM negative metasases were seen. Negative areas occasionally accounted for as much as forty percent of the metastatic tumour tissue.

\section{Discussion}

L-CAM expression in metastases has nor been extensively studied as yet. Schipper et al.' reported L-CAM expression in squamous cell carcinomas of head and 


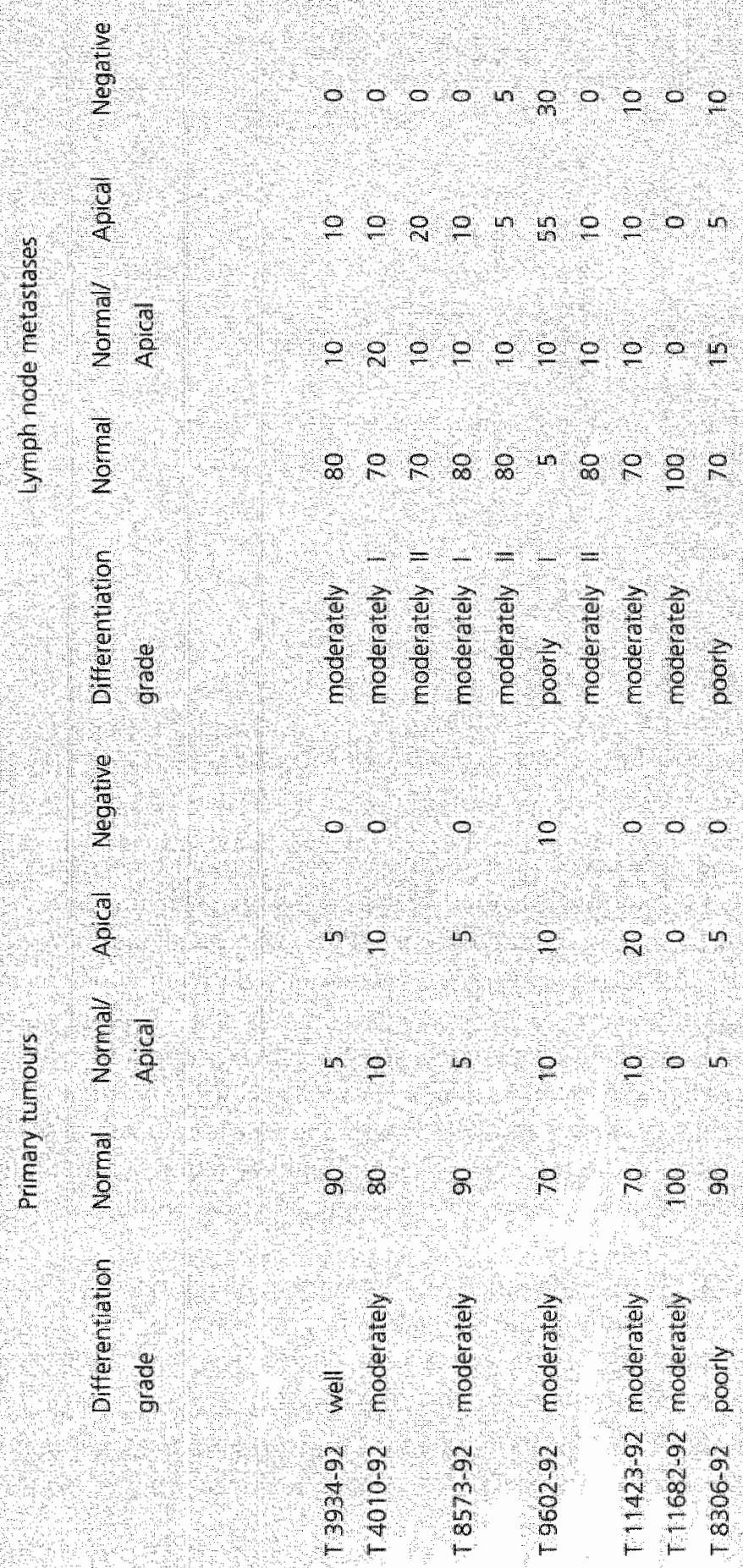


Tablie II LCAM expression in liwer netastases

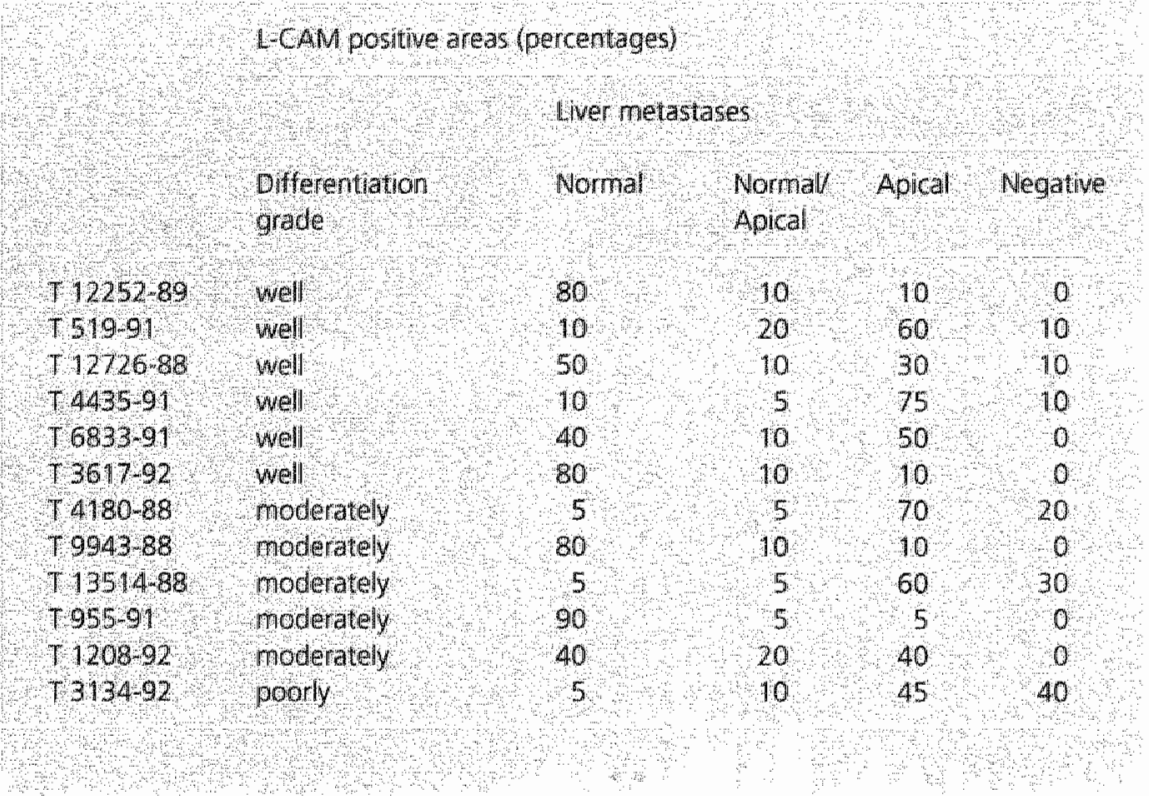

neck and their lymph node metastases by immunohistochemistry, immunoblotting and in situ hybridization. Well differentiated carcinomas expressed L-CAM as strongly as normal stratified epithelium, whereas all undifferentiated tumours were L-CAM negative. Also in seven out of eight lymph node metastases no L-CAM immunoreactivity was found. Dorudi er al. " used immunohisrochemistry and in siru hybridization to assess L-CAM expression in colorectal carcinoma. They also found a relation between L-CAM expression and differentiation grade. In cwenty out of $32 \mathrm{lymph}$ node metastases and in seven out of eight liver metastases no L-CAM expression could be found. These findings support the notion that loss of L-CAM expression is a prerequisite for the development of metastasis.

In several other studies L-CAM expression in lymph node metastases is mentioned. The results obtained in adenocarcinomas of the male and female genital tract $^{3.9}$ and in the digestive tract indicate that the expression pattern of L-CAM in the primary tumour reoccurs in the same intensity and extent in the merastasis. 
Assuming that loss of L-CAM expression is indeed a prerequisite for metastasis. these obserwations leave ar least two possibilives open: emergence of cell clones in the primary tumour with genetic alterations leading to reduced L-CAM expression or, alcernatively, remporary down regulation of L-CAM expression during the early phases of the metastatic cascade. In the present report we describe L.CAM immunoreactiviry patterns in colorectal carcinoma matastases.

L-CAM immunoreactivity in lymph node and liver metastases was predomimandy intercellular or apical, bue none of our cases showed total absence of L-CAM immunoreactivity. These results seem at variance with those reported by Dorudi et al." Methodological differences might account for these discrep-

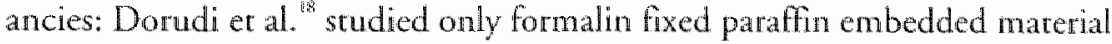
whereas we used unfixed cryostat sections. We have experienced that for the preservation of L-CAM immunoreactivity the duration of formalin fixation and the remperature during fixation are very critical (Dinjens at al., unpublished data). We previously studied L-CAM expiession in colorectal adenomas and carcinomas". In line with Dorudi et al." we found a correlation between L-CAM and differentiation.

In lymph node metastases the L-CAM staining pattern was comparable to that seen in the primary tumour although L-CAM negative areas were more promi nent than in the primary cumours. In liver metastases more extensive L-CAM negative areas were seen than in lymph node metastases or in primary tumours and a predominanty apical expression pattern was noted. This observation sug. gests that there might be differences between lymphogenous and haematogenous metastases. We have previously reported loss of expression of tissue antigens in haematogenous metastases, while lymph node metastases showed an antigen expression partern comparable to that of the primary tumour ${ }^{46}$. An explanation for this phenomenon could lie at the level of selection of subclones of cells differing in antigen composition and metastaric potential". Also tissue specific factors at the site of metastases and different mechanisms leading to lymphogenous or haematogenous metastases could play a role.

In contrast to Schipper et al. we did not observe torally L CAM negative metastases. Schipper et al. "suggest that a constitutive genetic change, such as a point mutation in the CDNA encoding the extracellular domain or in the L. CAM gene promotor, could be responsible for the lack of L-CAM expression ${ }^{\text {w. }}$. Our results, however, suggest a temporary rather than a constitutive L-CAM down regulation at the moment of invaston and L-CAM reexpression at the sire of metastases. Tumour cells can only detach from their epithelial environment and traverse the basement membrane into the stroma when cell-cell adhesions are severed. Once sertled in their new environment evidenty L-CAM is again expressed in order to reestablish tissue architecture. The molecular mechanisms 
responsible for this putative transient L-CAM down regularion remain to be elucidated.

\section{References}

\section{Takeichim.}

Cadherin cell adhesion receptors as a morphogenetic regulator.

Science 1991:251:1451-1455.

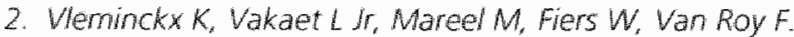

Genetic manipulation of E-cadherin expression by epithelial tumor cells reveals an invasion suppressor role.

Cell 1991; 66: 107-119.

3. Shimoyama $Y$, Hirohashi 5 , Hirano 5 , et al.

Cadherin cell adhesion molecules in human epithelial tissues and carcinomas.

Cancer Res 1989; 49:2128-2133.

4. Eidelman S, Damsky CH, Wheelock J, Damjanov l.

Expression of the cell-cell adhesion glycoprotein cell CAM 120/80 in normal human tissues and tumors.

Am I Pathol 1989; 135: 101-110.

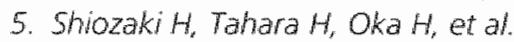

Expression of immumoreactive E-cadherin adhesion molecules in human cancers.

Am J Pathol 1991; 139:17-33.

6. Shimoyama $Y$, Hirohashi sincerely.

Expression of E-and P-cadherin in gastric carcinomas.

Cancer Res 1991: $51: 2185-2192$.

7. Schipper JH, Frixen UW, Behrens J, Andreas U, Jahnke K. Birchmejer W E-cadherin expression in sqaumous cell carcinomas of head and neck; inverse correlation with tumor dedifferentiation and lymph node metastasis

Cancer Res 1991: 51: 6328-6337.

8. Moue M, Ogawa H, Myata M. Shiozaki H. Tanizawa O.

Expression of E-cadherin in normal, benign, and malignant tissues of female genital organs.

A.CP 1992; $98: 76-80$

9. Umbas $R$, Schaiken $A$, Aalders $T$, Carter $B$ et al Expression of the cellular adhesion molecule E-cadherin is reduced or absent in high grade prostate cancer.

Cancer Res 1992:52:5104-5109. 
10. Wurff A van der, Ten Kate J, Linden Evan der, Dinjens W. Arends $1-W_{i}$ Bo5$\operatorname{man} F$.

L-CAM expression in normal, premalignant, and malignant colon mucosa.

IPathol 1992; 168; 287-293.

11. Nelson Wy, Shore EM, Wang AZ, Hammerton RW.

Identification of a membrane-cytoskeletal complex containing the cell adhesion molecule uvomorulin (E-cadherin), ankyrin, and fodrin in Madin-Darby canine kidney epithelial cells.

1 Cell Biol 1990; 110: 349-357.

12. Behrens 1, Mareel MM, Van Roy FM, Birchmeier W.

Dissecting tumor cell invasion: Epithelial cells acquire invasive properties after the loss of Uvomorulin-mediated cell-cell adhesion.

J Cell Biol 1989; 108: 2435-2447.

13. Frixen UH, Behrens J Sachs M, et al.

E-Cadherin-mediated cell-cell adhesion prevents invasiveness of human carcinoma cells.

J Cell Biol 1991; 113: 173-185.

14. Mareel MM, Behrens \&, Birchmeier $W_{s}$ et al.

Down regulation of E-Cadherin expression in madin darby canine kidney (MDCK)

cells inside tumors of nude mice.

int J Cancer 1991; 47; $922-928$.

15. Mareel $M$, Vleminckx $C$, Vermeulen $S$, et al.

Homotypic cell-cell adhesion molecules and tumor invasion.

Prog Histochem Cytochem 1992; 26: 95-106.

16. Arends J-W, Wiggers $T$, Verstijnen $C$, et al.

Tumour cell heterogeneity in primary and metastatic colorectal carcinoma.

Prot Biol Fluids 1984; 31 : 587-594.

17. Fidler U, Kripke ML.

Metatasis results from preexisting variant cells within a malignant tumour.

Science $1977 ; 197: 893-895$.

18. Dorudi S, Sheffield J, Poulsom $R$, et al

E-Cadherin expression in colorectal cancer. A immunocytochemical and in situ hybridization study.

Am J Pathol 1993; 142; $981-986$.

19. Ozawa M, Engel 1, Kemler P.

Single amino acid substitutions in one $C a^{z *}$ binding site of uromorulin abolish the adhesive function.

Cell 1990;63: 1033-1038. 
20. Behrens J, Lowerick O, Klen-Hitpass L, Birchmeier $W$.

The E-cadherin promotor: functional analysis of a GC-rich region and an epithelial specific palindromic regulatory element.

Proc Nall Acad So USA 1991; 88: 11495 11499.

\section{Acknowledgement}

Special thanks to Dr. J.H.J.M. van Krieken, parhologist at the State University of Leiden, The Netherlands, for the generous gift of snap frozen specimens of liver metastases of colorectal carcinomas. 
Chapter 6

Patterns of $\alpha$ - and $\beta$-catenin and E-cadherin expression in colorectal adenomas and carcinomas

Anna A.M. wan der Wurff, Stefan J.T. Vermeulen, Edith P.M. van der Lindien, Marc M. Mareel, Fred T,

Bosman and Jan-Willem Arends.

J Pathol $1997: 182: 325-330$ 


\section{Introduction}

In the process of invasion and metastasis, in which cancer cells traverse the basement membrane and reach distant sites via lymph and/or blood stream, cell adhesion plays an important role. Cell adhesion is brought about by molecules which are roughly grouped into four families: Cadherins, Integrins, Selectins and the Immunoglobulin superfamily of cell adhesion molecules ${ }^{2}$. E-cadherin, a member of the cadherin family, is expressed in epirhelial cells on the plasma membrane along intercellular borders, functions by way of calcium dependent komophilic adhesion ${ }^{3}$ and is linked to actin in the cytoskeleton via $\alpha$-, $\beta$-or y-catenin".

E-cadherin expression in cancer cells has been studied extensively. In in vitro as well as in vivo models, suppression of the expression of E-cadherin was shown to induce invasive behaviour". In human cancer tissues, some authors described reduced $\mathrm{E}$-cadherin immunoreactivity with a tendency rowards decreased $\mathrm{ex}$ pression allong with poor differentiation (for an overwiew see Mareel et al. ${ }^{8}$ ). These observations are in line with results obtained in model systems. It has also become clear, however, that in most invasive and metastatic human tumours $E$ cadherin is extensively expressed. In a previous study on a series of colorectal adenomas and carcinomas, we found a rendency for E-cadherin expression to be reduced in poorly differentiated carcinomas. Also, the cellular distribution of E-cadherin seemed to be altered in neoplastic cells: in addirion to lateral plasma membrane staning, apical staining was noted. A possible explanation for apical E-cadherin staining could be that the molecule is no longer linked to the cytoskeleton and therefore non-functional.

Several studies have shown that for functional cadherin mediared adhesion, the cactherin-catenin complex is crucial ${ }^{\text {rint! }}$. Defective cell adhesion occurred in vitro when E-cadherin expression was nor paralleled by $\alpha$-catenin expression ${ }^{10.12 .17}$. In functional terms, it is therefore preferable to consider the cadherin-catenin complex rather than its separate components ${ }^{13}$. In normal cells E-cadherin and the catenins show an idenrical pattern of expression. We hyporhesized that loss of cell-cell adhesion in invaswe cells might be associared with defective E-cadherin and/or a defective catenin expression which might be reflected in discrepancies beween the staining patterns for these proteins. To test this bypothesis, we used immunocytochemistry to detect $\alpha$-and $\beta$-catenin expression in normal and neoplastic human colorectal epithelia. The resules were compared with previously obrained E-cadherin staining patrems ${ }^{3,4}$. 


\section{Material and methods}

Surgical specimens of 12 colorectal adenomas (11 tubulovillous, 11 tubular) and 13 adenocarcinomas (3 well, 8 moderately well and 2 poorly differentiated adenocarcinomas) were obtained freshly. Nomal mucosa was excised from 10 colecromy specimens at a sire ar least five $\mathrm{cm}$ from the neoplasm. Also, 7 lymph node and 6 liver merastases of colorectal adenocarcinomas were sampled. Tissues were snap frozen in isopentane and stored at $-70^{\circ} \mathrm{C}$ until sectioning. Serial sections of $2 \mu \mathrm{m}$ thickness were cur, fixed in acerone at $-20^{\circ} \mathrm{C}$ for ten minutes, air dried, and stained. The sections were preincubared with normal goat serum in a dilution of 1:5 for ten minutes. An immunofuorescence method was used. Brielly, the sections were incubated with the polyclonal rabbir anci-a-catenin antiserum $^{13}$ diluted $1: 100$ and polyclonal rabbit anti- $\beta$-catenin antiserum ${ }^{\text {is }}$ in a dilution of 1:200 in phosphate buffered saline (PBS)-1\% bovine serum abumin (BSA) respectively (one hour, $\mathrm{RT}$ ) and after three wastings in $\mathrm{PBS}$, incubared with biotinylated goat anti-rabbit Fab fragments in a dilution of $4: 100$ (Nordic, the Netherlands) for thirry minuces. After repeated washing in PBS, sections were incubated with Auorescein-conjugated streptavidin (Dakoparts, Denmark) diluted 1:100 (30 min, RT). For E-cadherin immunostaining, the monoclonal antibody 6F9" (Eurodiagnostica, the Netherlands) was used, diluted 1:40 in PBS-1\% BSA. Sections were incubated with biotinylated sheep anti-mouse Fab fragments (Amersham, U.K.). Finally, they were rinsed In PBS, mounted in Immunomount (Shandon, Pitsburgh) and examined with a Zeiss LSM 410 confocal laser scanning microscope, equipped with a mixed argon/krypton gas laser. FITC fluorescence was excited with the $488 \mathrm{~nm}$ laser line and reconded using a 515 lp band pass filter.

For double staining, frozen sections were fxed and afer rinsing in PBS-1\% BSA, incubated with the $\beta$-catenin polyclonal antibody in a dilution of 1:100 $(30 \mathrm{~min}, \mathrm{RT})$, followed by an incubarion with horse anti-rabbit IFTC (Dakopatts, Denmark) (30 min, RT). Then, for E-cadherin staning the sections were subsequently incubated with E-cadherin monoclonal antibody $(1: 10,30 \mathrm{~min}$. $\mathrm{RT})$ and rabbit anti-mouse TRTTC $(1: 40,30 \mathrm{~min}$, RT). The sections were mounted in Vectashield (Vector Laboratories, USA).

In control slides, to check for cross-reactivicy, sections with carenin antibody were incubared with rabbit anti-mouse TRITC and sections with E-cadherin antibody were incubated with horse anti-rabbit FTC. Also a section was incubated solely with rabbit anti-mouse TRTTC and horse anti-rabbit FITC. No cross reactivity was observed (data not shown). FITC and TRTTC Auorescence was excired with the confocal laser scanning microscope and recorded using a dual excitation mode according to the manufacturers specification. 
Scoring was performed by two independent observers (AvdW and JWA). The following nomenclature was used: (1) Normal: a uniform expression along intercellular bonders. (2) Cyroplasmic: a diffuse cyroplasmic staining partern. (3) Apical: intensified immunoreactivity at the luminal cell surface without an intercellular staining partern. (4) Negarive: no immunoreacrivity ar all. Round percentages of positive staining areas were used as a guideline and are not based on numbers of counted cells.

\section{Results}

In nomal colon mucosa $\alpha$ - and $\beta$-catenin immunoreactivity was found along intercellular bonders of all epithelial cells. No immunoreacrivicy was seen at the basal side facing the basement membrane or at the luminal cell border. No difference was obserwed in rhe staining pattern between $\alpha$ - and $\beta$-catenin or $E$ cadherin (Fig. 1). Consistendy, colocalization of catenins and E-cadherin was found in double labeling experiments. Stromal staining was not found.

In adenomas, $\alpha$ - and $\beta$-catenin expression was found ar intercellular borders of all epthelial cells in the same intensity as seen in normal colonic mucosa. In addicion, weak cytoplasmic staining was noted in most specimens. a-Catenin expression usually appeared to be less intense than $\beta$-carenin expression, irrespective of grade of dysplasia. Also, E-cadherin expression showed the same immunoreactivity as in normal mucosa although staning intensity was less pro-

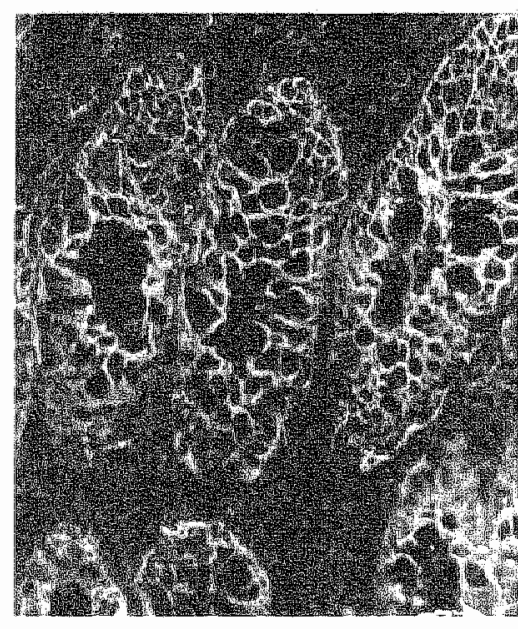

Figure 1. Caterin expression in nomal colon (5)ticona. nounced. Again, colocalizarion of carenins and E-cadherin was consistently found.

In the carcinomas in this series no totally catenin negative adenocarcinomas were encountered. No difference berween the $\alpha$ - and $\beta$-catenin staining patterns was found. The carcinomas showed intercelLular membranous staining, sometimes associated with faint cytoplasmic $\alpha$-and $\beta$-catenin staining, irrespective of differentiation grade. A semiquantitative analysis of staining patterns is presented in Table $\mathbb{1}$. Small negative areas (ren to twenty percent of the total tumour area) were noted in one poorly differentiated and in one moderately differentiated carcinoma. E-cadherin staining was reduced 
Table 1. Cadherin and catenin expression n carcinomas and ymph node melastases

Differemtiation Positive area $\mathrm{n}$
grade

\begin{tabular}{|c|c|c|c|c|c|}
\hline & & Gadiern & Catenm & Cadhering & Cateni \\
\hline $71417-90$ & well & $80 \%$ & $100 \%$ & nd & nd: \\
\hline 7870690 & Well & $100 \%$ & $100 \%$ & nd & nd \\
\hline 1399490 & Welt & $100 \%$ & $100 \%$ & $100 \%$ & $100 \%$ \\
\hline 1799390 & Moderate & $100 \%$ & $100 \%$ & $\mathrm{nol}$ & nd \\
\hline 1809790 & Moderate & $100 \%$ & $100 \%$ & nd & nd \\
\hline 1401092 & Moderate & $100 \%$ & $100 \%$ & $100 \%$ & $100 \%$ \\
\hline $18573-92$ & Moderate & $100 \%$ & $100 \%$ & $100 \%$ & $80 \%$ \\
\hline 1960292 & Moderate & $90 \%$ & $80 \%$ & $70 \%$ & $80 \%$ \\
\hline $111423-92$ & Noderate & $100 \%$ & $100 \%$ & $90 \%$ & $80 \%$ \\
\hline $\mathrm{T} 1168292$ & Moderate & $100 \%$ & $100 \%$ & $100 \%$ & $100 \%$ \\
\hline 1162690 & Moderate & $95 \%$ & $100 \%$ & net & nd \\
\hline $7 / 39490$ & roor & $100 \%$ & $100 \%$ & nod & nd \\
\hline $\mathrm{T} 830092$ & Poor & $100 \%$ & $90 \%$ & $90 \%$ & $100 \%$ \\
\hline
\end{tabular}

Table II Cadherin and catenin expression in liver metastases.

Differentiation grade

\begin{tabular}{|c|c|}
\hline 38 & Well \\
\hline 135 & Moderatie \\
\hline 744 & Wel \\
\hline 5 & Well \\
\hline $33 \times 91$ & . \\
\hline 6179 & \\
\hline
\end{tabular}

Positive area

Cadherin Catenin

$\begin{array}{cr}90 \% & 100 \% \\ 70 \% & 100 \% \\ 90 \% & 100 \% \\ 90 \% & 100 \% \\ 100 \% & 80 \% \\ 100 \% & 100 \%\end{array}$

(five to twenty percent of the toral tumour area unstained) in one well differenciaced and in two moderately differentiated carcinomas. One of these noderately differentiated carcinomas showed small areas of loss of catenin immunore- 
Table II. Cadhernand catenin staining (carcinomas and metastases) and differentiation.

\begin{tabular}{|c|c|c|c|c|c|}
\hline Diferentiation grade & Number & E-Cadherin & & Catenin & \\
\hline & & normal a & aberrant & normal' & aberrant \\
\hline ati & 9 & 5 & 4 & 8 & 1 \\
\hline Moderate & 14 & 9 & 5 & 10 & 4 \\
\hline poor & 3 & 2 & 1 & 2 & 1 \\
\hline
\end{tabular}

1. Nomal 1 e an intercelluar staning pattern in the total tumour

2. Aberrant le. a negative, apical andor cytoplasmic staining pattern in warious percentages of the total tumour area(see text)

Table IV, Comparison of cadherin and catenin staining in colorectal adenocarcinomes and metastases:

\section{Staning pattem 14 Number}

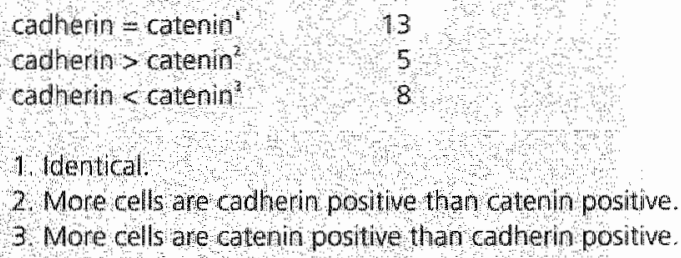

2 More cells are cadhe in positive than caterin positive.

3. More cells are catenin positive than cadherin positive.

activicy occasionally paralleted by loss of cadherin reacrive, for E-cadherin as well as for the carenins, the apical immunoreactivity pattern is noteworthy. In most cases coexpression of $\mathbb{E}$-cadherin and catenins was found (figg. 2 and lig. 3), but in a total of four tumours (one well, two moderately and one puorly differenciated) small percentages of tumour areas were notcd where catenin staining was not paralleled by E-cadherin staining and vice varsa.

All lymph node (Table I) and liver metastases (Table II) displayed nembranous $\alpha$-and $\beta$-atenin immunoreactivity, though somermes we (Fig. 4 and Fig. 5). In addition, these tisstes showed cytoplasmic staining of wriable intensicy. No significant differences were found in staining partern or intensity between 


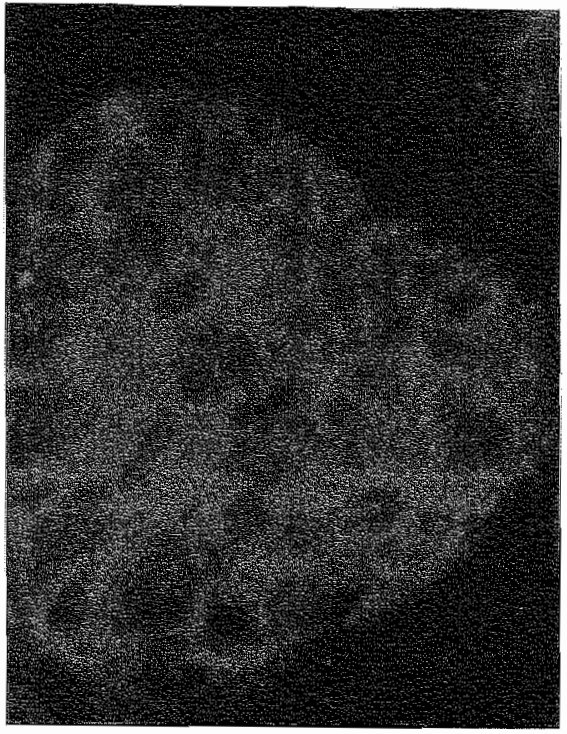

Figure 2. Catenim expression in colorectal adenocarcinoma.

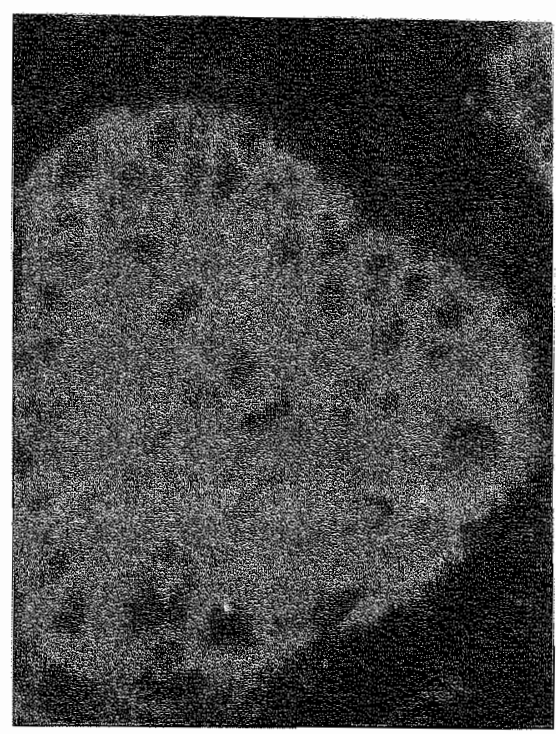

Figure 3. Double staning inmunoHluorescence for catenin and E-cadherin.

lymph node metastases or primary tumours. Three out of five lymph node metastases from moderately differentiated adenocarcinomas showed in a maximum of twenty percent of the total tumour area lack of $\alpha$-and $\beta$-catenin staining. $E$ cacherin showed ten to thirry percent negative staining area in two moderately differentiated and one poorly differentiated lymph node metastasis. In both of these moderately differentiated metastases catenin negative areas were occasionally parallelled by loss of cadherin immunoreactivity. In a rotal of four metastases (from three moderarely and one poorly differentiated primary tumour), small percentages of total tumour areas were seen where caten in staining was not paralleled by E-cadherin staining and vice versa.

Of the liver metastases no corresponding primary tumours were available. One well differentiated liver metastasis showed a negative staining area of twenty percent for $\alpha$-and $\beta$-carenin. For E-cadherin, negative staining areas varying from thirty to ten percent were noted in three well and one moderately differentiated liver metastases. In a total of five liver motastases, small percentages of cotal tumour areas were noted where carenin staining was not paralleled by E-cadherin staining and vice versa. A summary of the dara on carcinomas and metastases is presented in Table III. This together with the summary in Table IV reempha- 


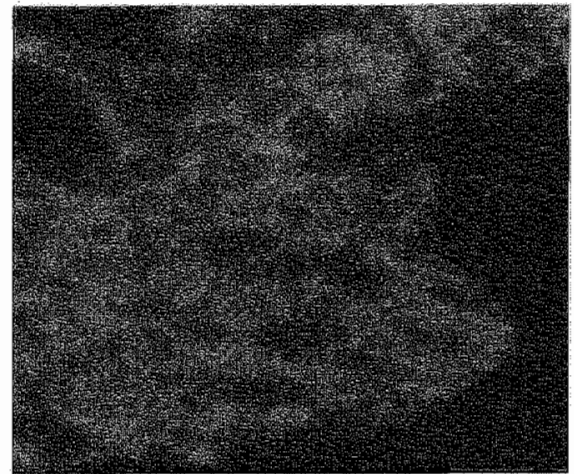

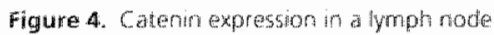
metastess. E-codherin showit the same immunoreactivity pattern?

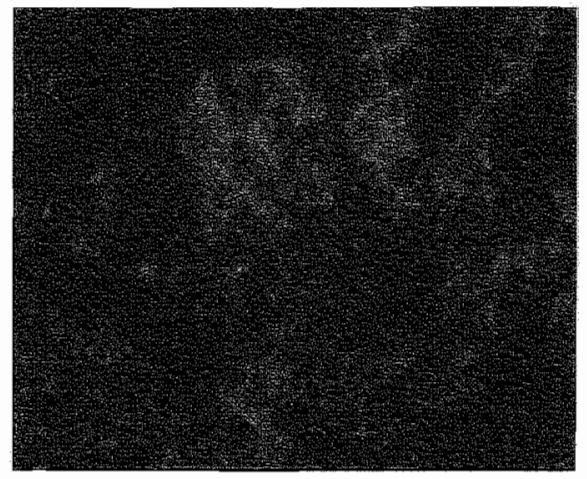

Figure 5. Catenin expresson in a liver metastasis. Ecadherin showed the same inmunoreactivly pattern.

sizes our most important observation that in fifty percent of the studied colorecval carcinomas and metastases, E-cadherin and $\alpha$ - and $\beta$-carenin expression were identical. When not identical, small percentages of total rumour areas showed carenin staining without $E$-cadherin staining and vice wersa, while $\alpha$ - and $\beta$-carenin staining were always identical. Occasionally rumour cells withour carenin and cadherin immunoreactivity were seen.

\section{Discussion}

Connection of the cytoplasmic domain of cadherin by catenins to the actin filament nerwork of the cyroskeleton is thought to be essenrial for the adhesive function.

Studies on cell lines indeed showed that E-cadherin funcrion is mediated by catenin ${ }^{1 m-1}$. In immunohistochemical studies on tissue secrions of carcinomas of the human gastro-intestinal tract, including colonic adenocarcinomas", reduction of carenin expression was found to be significantly related to poor differentiation, depth of invasion, infiltrarive growth and lymph node metastasis ${ }^{13-15}$. In previous studies "we noted that lymph node metastases of primary tumours expressing E-cadherin showed a comparable E-cadherin immunoreactivity patuch. We therefore postulated that E-cadherin might be rransiently downregulated during migratory phases of invasion and we concluded that E-adherin cannot be used as a prognostic indicator of invasion in colorectal adenocarcinomas. In view of recent publications on the role of the carenins in cadherin function ${ }^{162 t}$ we hypothesized that tumours with a normal partern of E-cadherin immunoreacrivity might nevertheless be cell-cell adhesion deficient due to an 
ineffective E-cadherin-carenin complex. Disturbance of the E-cadherin-carenin complex by loss of the connection of E-cadherin to the cytoskeleton migh also be responsible for the apical E-cadherin expression partern we previously described in adenomas and carcinomas of the colorectum". We therefore compared $\alpha$-and $\beta$-catenin localizacion with that of E-cadherin in colorectal adenomas, carcinomas and their lymph node and liver merastases.

In normal colonic mucosa, catenin expression was located on cell membranes along intercellular interfaces, in a pattern identical to thar of E-cadherin. In adenomas a corresponding staining parrem was nociced. In only few adenocarcinomas the catenins showed some focal loss of immunoreacrivity which was occasionally but not always paralleled by loss of E-cadherin staining. Also, the reverse phenomenon was observed: E-cadherin staining without $\alpha$-and $\beta$-catenin staining. In lymph node and liver merascases similar results were obtaned. No difference in staining pattern between $\alpha$-and $\beta$-catenin was found. Therefore, in invasive neoplasms caten in downregulacion was nor consistent nor did consistent downregulation of E-cadherin immunoreactivity occur. The apical. E-cadherin staining pattern was paralleled by an apical catenin pattern.

As a consequence, invasive behaviour of E-cadherim positive rumours can only in few cases in small areas of the tumour be explained by lack of catenins in the E-cadherin-catenin complex. This is in contrast with the results of a study by Takayama et al. in which he concluded that downregulated $\beta$-catenin expression is associated with malignant ransformation. The difference could be explained by the number of poorly differentiated tumours studied. However in our study of primary cumours and metastases we show that in colorectal cancer invasive and metastatic behaviour is not paralleled by a consricurive decrease in expression of the componenus of the E-cadherin-catenin complex. An explanacion for metastasis in E-cadherin and catenin positive rumours could be rransient loss of cell-cell adhesion during invasion as a result of ransient downregulation of the expression of E-cadherin as well as of catenins. Alcmandy, the observed immunoreactive E-cadherin and catenin could be dysfunctional, for example as a result of gene mutarions or through postranslational modificarions. It has been shown that tyrosine phosphorylation of the E-catherincatenin complex by v-src or Epidermal Growth Factor ( $\mathrm{GCF}$ ) is associated with loss of cell adhesive properties ${ }^{\text {"I.n? }}$. Of particular interest in colorectal adenocarcinomas is the possibilicy that the functional state of cell-well adhesions and theit linkage with the cytoskeleton could be altered under influence of a murated APC gene product. The latter possibility is especially interesting in view of recent publications about binding of the APC oncosuppressor gene product to $\beta$-catenin ${ }^{2 *}$. Our observations indicate that in most of colorectal cancers the majority of the cancer cells display a normal (matching) partern of F-cadheriu 
and catenin expression. Aberrant expression of the E-cadherin-catenin complex on the plasmamembrane might be inferred from the apical staining pattern which was occasionally nored. Disruption of the E-cadherin-catenin complex was noted both in terms of E-cadherin and/or catenin loss.

In conclusion, matching patterns of $\mathrm{E}$-cadherin and $\alpha$ - and $\beta$-catenin staining in normal and mose neoplastic colorecral epithellia were found. An incomplete E-cadherin-catenin complex in terms of either decreased E-cadherin staining and/or decreased carenin staining was found in a few cells of a number of adenocarcinomas. These findings exclude the use of E-cadherin or catenin staining of colorectal lesions for diagnostic or prognostic purposes bur open interesting new possibilities regarding the functional disturbances of cell adhesion during invasion.

\section{References}

\section{Edelman GM, Crossin KL}

Cell adhesion molecules: implications for a molecular histology.

Annu Rev Biochem 1991;60: 155-190.

\section{Takeichim.}

Cadherin cell adhesion receptors as a morphogenetic regulator.

3. Takeichim.

Cadherins: a molecular family important in selective cell-cell adhesion.

Annu Rev Biochem 1990;59: 237-252.

4. Ozawa M, Ringwald $M$, Kemier R.

Uvomorulin-catenin complex formation is regulated by a specific domain in the cytoplasmic region of the cell adhesion molecule.

Proc Natl Acad Sci U S A 1990:87: 4246-4250.

5. Veminckx K, Vakaet L Ir, Mareel M, Fiers W, van-Roy $F$.

Genetic manipulation of E-cadherin expression by epithelial tumor cells reveals an invasion suppressor role.

Cell 1991;66: 107-119.

6. Dorudi 5, Sheffield IP, Poulsom R, Northover MM, Hart IR.

E-cadherin expression in colorectal cancer. An immunocytochemical and in situ hybridization study.

Am J Pathol 1993;142: $981-986$. 
7. Schipper JH, Frixen UH, Behrens J, Unger A, Jahnke K, Birchmeier W.

E-cadherin expression in squamous cell carcinomas of head and neck: inverse correlation with tumor dedifferentiation and lymph node metastasis

Cancer Res 1991:51:6328-6337.

8. Mareel M. Bracke M. Van-Roy F.

Invasion promoter versus invasion suppressor molecules: the paradigm of E-cadherin. Mol Biol Rep 1994:19:45-67.

9. van-der-Wuff AA, ten-Kate J van-der-Linden EP. Dinjens WM, Arends MW. Bosman FT.

L-CAM expression in normal, premalignant, and malignant colon mucosa.

i) Pathol 1992;168: 287-291.

10. Shimoyama $Y$, Nagafuchi A. Fujita $S$, et al

Cadherin dysfunction in a human cancer cell line: possible involvement of loss of alpha-catenin expression in reduced cell-cell adhesiveness.

Cancer Res 1992:52: $5770-5774$.

11. Morton RA, Ewing CM, Nagafuchi A, Tsukita S, Isaacs WB.

Reduction of E-cadherin levels and deletion of the alpha-catenin gene in human prostate cancer cells.

Cancer Res 1993:53: 3585-3590.

12. Breen E, Clarke $A$, Steele $G$ Jr, Mercurio AM.

Poorly differentiated colon carcinoma cell lines deficient in alpha-catenin expression express high levels of surface E-cadherin but lack $\mathrm{Ca}(2+)$-dependent cell-cell adhesion.

Cell Adhes Commun 1993;1: 239-250.

13. Shrozaki H. Whara K. Oka H. et al.

Immunohistochemical detection of alpha-catenin expression in human cancers.

Am I Pathol 1994; 144:667-674.

14. Kadowaki $T$, Shiozaki $H$, nove $M$, et al.

E-cadherin and alpha-catenin expression in human esophageal cancer.

Cancer Res 1994:54:291-296.

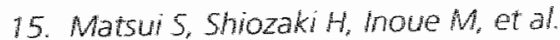

immunohistochemical evaluation of alpha-catenin expression in human gastric cancer.

Virchows Arch 1994:424: 375-38\%.

16. van-der-Wurff AA, Arends JW van-der-Linden EP, Ten-Kate : Bosman FT. L-CAM expression in lymph node and liver metastases of colorectal carcinomas.

I Pathol 1994:172:177-181. 
17. Vermeuten Sl, Bruyneel EA, Bracke ME, er al.

Transition from the noninvasive to the invasive phenotype and loss of alpha catenin in thuman colon cancer cells.

Cancer Res 1995,55: 4722-4728.

18. Vermeulen 5:, Bruyneel EA, Roy FM wan, Mareel MM, Bracke ME.

Activation of the E-cadherin/Catenin complex in human MCF-7 breast cancer cells by all-trans-retinoic acid.

Br J Cancer 1995;72:1447-1453.

19. Frixen UH, Behrens J, Sachs $M$, et al.

E-cadherin-mediated cell-cell adhesion prevents inwasiveness of human carcinoma celis.

1 Cell Biol 1991:113:173-185.

20. Takayama T, Shiozaki H, Shibamoto S, et al.

$\beta$-Catenin expression in human cancers.

Am J Pathol 1996:148:39-46.

21. Behrens J, Vakaet L. Friss $R$, et al.

Loss of epithelial differentiation and gain of invasiveness correlates with tyrosine phosphorylation of the E-cadherinbeta-catenin complex in cells transformed with a temperature-sensitive $\mathrm{w}$-SRC gene.

ICell Biol 1993:120:757-766.

22. Shiozaki H, Kadowaki T, Doki Y, et al.

Effect of epidermal growth factor on cadherin-mediated adhesion in a human oesophageal cancer cell line.

$\mathrm{Br}$ J Cancer 1995;71: 250-258.

23. Su LK, Vogelstein $B$, Kinzler KW.

Association of the APC tumor suppressor protein with catenins.

Science 1993:262: 1734-1737.

24. Rubinfeld B, Souza B, Albert l, et al.

Association of the APC gene product with beta-catenin.

Science 1993;262: 1731-1734.

\section{Acknowledgement}

Special thanks are due ro C.J. Vissers and W.N.M. Dinjens for excellent immumohistochemistry and to A.B. Houtsmuller for confocal analysis. 


\section{General discussion}

The aim of this study was to identify new prognostic indicarors in colorectal adenocarcinoma. The presently available indicators allow relatively useful subdivision of parients according to depth of invasion, lymph node involvement, venous invasion and degree of differentiation. Of these parameters, degree of differentiation is the least defined, as it is based principally on a rather subjecrive visual impression. The problem with the presently available subdivisions, however, is that they - in spite of significant correlations between pathological characteristics and numour behaviour at a population level - do not allow individualisation of clinical managment options. The availability of additional criteria to fine-tune prognostic indications would be of tremendous clinical importance. The approach chosen in this thesis for identificarion of new prognostic indicators is more or less standard: definition of a new parameter and retrospecrively comparing its status in individual cases with tumour behaviour in terms of prognosis, derermining its potential usefulness. Unfortunarely, most clinicopathological studies focusing on new prognostic markers scop there. This seriously limits a large majority of prognostic studies: a lack of prospective use of a porentially important new parameter as a decisive factor in clinical management of individual patients. An important need in the near future therefore, is the development of prospective trials in which new prognostic markers are used as main determinants for selecting among different awailabe patient managment modalities. This holds true nor only for colorectal cancer but for almost any tumour type.

Our strategy for the identification of new markers in this study has been defined by prior knowledge regarding the biology of colorectal cancer. We opted for two parallel approaches. Firstly, we decided to look for new parameters related to differentiation, given the fact that differentiation is already in use as parameter but lacks a conceptual basis and clearly defined criteria. Secondly, we decided to study the E-cadherin/catenin family of cell adhesion proteins, knowing that disturbance of cell-cell adhesion plays an important role in the development of invasive growth.

In looking for new markers related to differentiation our working hypothesis was that not the terminally differentiated cells but the immature tumour stem cells are responsible for tumour behaviour because they are clonogenic. Therefore we set our to develop antibodies against immature crype (stem) cells assum- 
ing that these would identify proteins that could function as markers in a more refined classification scheme for colorectal cancer. In order to eliminate common crypt cell antigens during or prior to immunization, we used antibody blocking of common crypt cell antigens and in wivo selection of the immune response by wy of cyclophosphamide. This efforr resulred in a monoclonal ancibody, 5E9, which stains goblet cells in the lower half of the crypt. Upon biochemical characterization 5 Eg appeared to recognize a non-sialylated catbohydrate epirope on Muc2. Muc2 is the prominent secretory mucin in the human colon". Mucins in colorectal cancer, either on the cell surface or in the cytoplasm, have not been studied to the same extent as the genetic changes that presumably underlic the development of colorectal cancer. There is sufficient evidence, however, that mucins consriture biologically active molecules involved in the fundamental funcrional changes that occur in the transformaxion of an ordinary epithelial cell into a cancer cell and in tumour progression ${ }^{2}$. In a recent study expression of the Mucl, Muc3, TF, Th and STn mucins and mucin associared glycotopes was examined in colorectal adenomas and carcinomas. Along with tumour development and -progression Mucl. TF. Tn and STn showed increased immunoreacrivicy along with a shift from apicall and/or supranuclear expression to an apolar pattem of expression. In contrast, Muc3 showed unaltered intensity of immunoreactivity but a similar change of pattern towards apolar". These results reinforce the notion that, during carcinogenesis in the colon mucins show characteristic changes of glycosylation and of distribution. A similar study reported that upon malignant ransformation expression of Mucl, a non-secretory cell membrane associated glycoprotein, is upregulated and that this accounts for a worse prognosis". It has also been described that high grade arypia in colorecal adenomas is characterized by reduced immunohistochemical expression of Muc2 $2^{4}$. Furthermore, Muc2 gene expression was found in noninvasive rumours but not in invasive tumours of pancreas and liver". Our Muc2 epitope, identified by 5 E9, recognized a subser of Dukes B carcinomas with a urend towards worse prognosis. Our hypothesis is that 1 . in the colon the 0 glycosylation partern of Muc2 changes when the crypt cells maturate and migrate upwards to the bowel lumen. 2. that tumour stem cells reain this immature Muc2 epirope and 3. that expression of this epitope is related with a more aggressive rumour cell phenotype. In principle, these bypotheses should lead to addicional experiments and sucl experiments might shed more light on the role of mucins in epithelial cel differentiation in the colorecum and on their use as "umour makkers in a clinical context.

Our experiments described in chapter 2 illustrate the difficultes encountered in atrenpting ro generare hybridomas with "tailored" specificity. It is quite conceivable that the use of new mathods in biotechnology, such as the phage dis- 
play technique, might prove a more promising approach towards the development of new antibodies recognising new potentially useful markers. This consideration has led to experiments in which carefully selected panels of tumour cells or tissues are used to screen phage display libraries for the presence of antibodies recognizing interesting new epitopes.

Our second line of srudy focused on expression of members of the Ecadherin/catenin complex during colorectal carcinogenesis and tumour progression. The initial working hypothesis was that upon progression towards invasion E-cadherin, a purative invasion suppressor gene, would be no longer expressed either through loss of function "through mutarion or through transcriprional down regulation. Our findings, confirming similar studies in the literature which concern a variery of organ systems and cumour types, indicate that in metastatic lesions E-cadherin expression is not constitutively lost (for an overview see Mareel et al."). In developing neoplasms the step towards invasion is probably marked by focal loss of E-cadherin expression but nor due to mularional loss, at least in most instances. E-cadherin mutations have been found in a limited number of only some tumour types (most notably lobular cancer of the breast and diffuse type of gastric cancer ${ }^{*}$ ). This implies that E-cadherin expression in the inirial phase of expression is temporarily downregulared, only to be reexpressed by the metastatic cells when they have to re-establish tissue architecture in the metastatic lesion.

Meanwhile, the situation has become much more complex with the involvement of the catenins in the E-cadherin/catenin complex. We found overall matching patterns of $\mathbb{E}$-cadherin and $\alpha$-and $\beta$-catenin staining patterns. This finding is comparible with the concept of loss of function of the E-cadherin/catenin complex through decreased expression or loss of function of any one of irs components. Mutations of $\alpha$ - and $\beta$-catenin have been found "." In addition, $\beta$-catenin function can be abolished through phosphorylation and its phosphorylation has been described by the EGFR, c-erbB-2, c-met and $p p 60$ " (for an overview see llyas er al. "). Interestingly, $\beta$-catenin function is also controllct by $\mathrm{APC}$ ( the gene producr of the familial polyposis colligend), which comperes with E-cadherin for $\beta$-catenin binding ${ }^{1.11}$. The APC mutations (which accorting to the latest concept are the earliest generic testons in colon carcinogenesis" truncate APC protein, which then can bind but not inactivate $\beta$-catenin. "This leads to increased cytoplasmic $\beta$-catenin. An important signaling function of $\beta$-carenin is binding to hTcf-4, a transcription factor which is activated only when complexed to $\beta$-catenin ${ }^{15 \%}$. It is now assumed that this transcription activation may be one of the earliest steps in colorectal carcinogenesis.

Taken together, these dara indicate that parterns of expression of the members of the E-cadherin/catenin complex cannor reliably indicate propensity rowards 
invasive growth. In a clinicopachological concex the correlation of expression with differentiation might be promising. More importantly, the E-cadherin studies have prowided new insight in the dynamics of cell adhesion and irs role in the process of invasion. The catenin studies have opened up new concepts regarding the role of $\mathrm{APC}$ in intracellular signaling and the contributory role of B-atenin.

Few of the goals inirially aimed for at the beginning of our studies have been attained. Much has been learned, however, in terms of tumour biology and so indirectly with an impact on clinical aspects of the biology of colorectal cancer. Only through betrer understanding of the biology of this disease will parhalogists be able to develop new parameters to clearly define biological potencial of tumours in individual patients. Only through the use of such new descriptors in prospecrive clinical studies can such parameters be validated.

\section{References}

1. Tytgat KMAJ, Buller HA, Opdam FM, et al.

Biosynthesis of human colonic mucin: MUCZ is the prominent secretory mucin

Gastroenterology 1994, 107: 1352-1363

2. Cao Y, schlag PM, Karsten U.

Immunodetection of epithelial mucin (MUC1, MUC3) and mucin-associated glycotopes (TF, Tn, and sialosyl-Tn) in benign and malignant lesions of colonic epithelium: apolar localization corresponds to malignant transformation.

Virchows Arch 1997, 431: 159-166

3. Alloka $Y$, Allison U Jass JR.

Significance of MUC1 and MUC2 mucin expression in colorectal cancer.

J Clin Pathol 1996, 49: 560-564

4. Ajioka $Y$, Watanabe $H$, Jass JR.

MUC 1 and MUC2 mucins in flat and polypoid colorectal adenomas.

I Clin Pathol 1997, 50: 417-421

5. Yonezawa 5 , Sweyoshi $K$, Nomoto $M$, et al.

MUC2 gene expression is found in noninvasive tumors but not in invasive tumors of the pancreas and liver: its close relationship with prognosis of the patients.

Human Pathology 1997, 28: 344.352

6. Mareel M, Bracke M. Van-Roy F.

Invasion promoter versus invasion suppressor molecules: the paradigm of E-cadherin. Mol Biol Rep 1994. 19: 45-67 
7. Becker KF, Atkinson M, Reich U, et al.

E-cadherin gene mutations provide clues to diffuse type gastric carcinomas.

Cancer Res 1994, 54:3845-3852

8. Kanai Y, Oda T, Tsuda H, Ochiai A, Hirohashis.

Point mutation of the E-cadherin gene in invasive lobular carcinoma of the breast.

Jpn J Cancer Res 1994, 85: 1035-1039

9. Kawanishi J, Kato J. Sasakik et al.

Loos of E-cadherin-cependent cell-cell adhesion due to mutation of the b-catenin gene in a human cancer cell line, HSC-39.

Mol Cell Biol 1995, 15: 1175-1181

10. Morton RA, Ewing CM. Nagafuchi A, Tsukita S, Isaacs WB.

Reduction of E-cadherin levels and deletion of the alpha-catenin gene in human prostate cancer cells.

Cancer Res 1993, 53: $3585-3590$

11. Iyas M. Tomlinson IPM.

The interactions of APC, E-cadherin and b-catenin in tumour development and progression.

J Pathol 1997, 182:128-137

12. Su LK, Vogelstein $B$, Kinzler KW.

Association of the APC tumor suppressor protein with catenins.

Science 1993, 262: 1734-1737

13. Rubinfeld B, Souza B. Albertl, et al.

Association of the APC gene product with beta-catenin.

Science 1993, 262: 1731-1734

14. Kinzler KW, Vogelstein $B$. Lessons from hereditary collorectal cancer.

Cell 1996, 87: 159-170

15. Korinek $V$. Barker $N$. Morin PJ, et al.

Constitutive transcriptional activation by a $\beta$-catenin $T$ f complex in APC $/$ colon carcinoma.

Science $1997,275: 1784-1787$

16. Morin PJ, Sparks $A B$, Korinek $V$, et al. Activation of $\beta$-catenin-Tef signaling in colon cancer by mutations in $\beta$-catenin or $A P C$.

Science 1997, 275: 1787-1790 



\section{Summary}

Chapter 1 comprises a general introduction to the field of study and describes the aims of the study.

In chapter 2, which is like a material and merhod paragraph in this thesis, we describe the selection of specific colon crypt cell subpopulations and some immunization protocols. In order to obtain monoclonal anvibodies against immature (stem) cells, we tried to elminate common crypt cell ancigens during or prior to immunization by way of in vivo selection of the immune respons using cyclophosphamide and by ancibody blocking of common orypt cell antigens. The obtained antibodies are described in short.

The aim of the study described in chapter 3 was to develop monoclonal antibodies that recognize antigens on immanure crypt base cells, on the assumption chat in a neoplasm undifferentiated bur not the terminally differentiated cells will be responsible for tumour progression. We used colon crypr cells which were isolated from human colonic mucosa by EDTA/EGTA incubarion. By stepwise harvesting, crypt base cell enriched fractions were obtained, and after incubation with antibodies against dominant antigens, used as immunogen. Of one crypt base cell specific antibody $(5 \mathrm{E} 9)$, the reactive epitope appeared to be a non-terminal carbohydrate in the mucin O-glycans of the colon. The epirope seemed not to be colon specific, but is expressed in a variety of other tissues. In colorectal carcinomas, 5 E9 immunoreactivicy identified a subgroup of parients with a rendency for worse prognosis. This study shows that we identified a mucin associated maturation epirope in colonic crypt base cells, of which the expression in colorectal carcinoma stage Dukes B3 may be associared with worse prognosis.

L-CAM, also known as E-cadherin, is a cell adhesion molecule, which is expressed at the incencellular borders of most epithethal odls. In carcinoma cell lines L-CAM has been demonstrated to act as an imwasion suppressor. In order to determine wherher or not L-CAM expression might distinguish berween inwasive and non-invasive or metascaric and non-metastatic colon neoplasms, in chapter 4 we studied L-CAM expression in nomal colon mucosa, colon adenomas with various degrees of dysplasia and colon carcinomas by immunohistochemistry, using the 6F9 monoclonal and L-CAM antibody. Normal nucosa showed evenly distributed distinct L-CAM immunoreactivity along intercellutar borders. In adenomas as well as carcinomas a similar though weaker expression 
was observed. This pattem showed a trend to decrease in parallel with decreasing differentiation. No correlation, however, was found with Dukes stage or area within the rumour. In some carcinomas L-CAM was expressed at the luminal surface of the cells. In others L.CAM expression was nor found.

In chapter 5 we describe L.CAM expression in lymphogenous and haematogenous metastases of large bowel adenocarcinomas, using an indirect immunoperoxidase method with the monoclonal ant- - -CAM antibody 6F9. All situdied merastases-lymphogenous as well as haemarogenous -demonstrated L-CAM immunoreactivity in a pattern comparable to that of primary tumours. Intratumour heterogeneity in expression was noted, with normal intercellular apical (non-funcional) and focally negative areas in the same tumour.

The data indicate that primary tumours and their metastases do not differ strikingly in their partern of L-CAM expression. This would be consistent with transient rather than constitutive dowin regulation of L-CAM in invasive and metastatic cancer cells.

These resuls of both studies suggest that L-CAM expression is disregulated or lost as an early event in the development of colon neoplasia and indicate that L-CAM expression does not correlare with invasive or metastatic potential. Previous in vitro and in vivo model studies have show that when E-cadherin expression in carcinoma cells is reduced, invasive behaviour ensues. The situation in thuman cancer in vivo, however, appears to be more complex as immunohistochemically determined E-cadherin expression in various carcinomas, including colorectal cancer, does not always correlate with invasive growth. Loss of cell adhesion during invasion in spite of E-cadherin expression might be associated with a defective cadherin-catenin complex. In chapter 6 we examined the expression of $\alpha$-and $\beta$-catenin in comparison wirh $E$-cadherin in colorectal adenomas and carcinomas and in lymph node and liver metastases.

In normal colon mucosa, $\alpha$ - and $\beta$-catenin immunoreactivity occurred along the lateral plasma membrane of the epithelial cells, in a partern idencical to Ecadherin staining. A similar pattern was found in colorectal adenomas and in most malignancies. In gencral, in neoplasric cpithelia, the majority of the cancer cells displayed a nomal (matching) pattern of E-cadherin and catenin expression.

We conclude that the patterns of expression of E-cadherin and $\alpha$ - and $\beta$-catenin are highly similar in colorectal neoplasms. This observation indicates that invasion in colorectal cancer is not paralleled by consistent loss of expression of the components of the cadherin-catenin complex. 


\section{Samenvatting}

Hoofdstuk 1 geeft een algemene inleiding en beschrijft her doel van het onderzoek dat in dit proefschrift wordt beschreven. In het kankeronderzoek is men op zoek naar manieren om die gezwellen te herkennen die zich al in een vroeg stadium uitzaaien. Wij hebben ons beziggehouden met kanker van de dikke darn en hebben onderzocht, of het mogelijk is om aan de hand van de aanwezigheid van ongedifferentieerde cellen een voorspelling te doen over het gedrag van een tumor (hoofdstuk 3) en of voorspellende waarde kan worden toegekend aan de aanwezigheid van cadherine (hoofdstuk 4, 5 en 6).

In hoofdstuk 2 worden de technieken beschreven die in dir onderzoek gebruikt zijn. De bekleding van de dikke darm - die in plooien (crypten) ligt - bestaat uir verschillende celsoorten. Uit deze celsoorten hebben we geprobeerd de zogenaamde stamcel te isoleren, die zich onder in de crypr bevindt. In deze stamcellen vinden alle cellen van de darmbekleding hun oorsprong. Isolatie van stamcellen is ons niet gelukt. Wel zijn we erin geslaagd cryptbodems te isoleren, waarin zich de stamcel bevind naast cellen in een vroeg ontwikkelingsstadium (ongedifferentieerde cellen).

Tevens beschrijf ik enkele manieren om muizen te gebruiken voor het maken van door ons nader gedefinieerde anitichamen. Antilichamen zijn eiwituen, gericht tegen lichaamswreemde stoffen. Door middel van kleuring kunnen antilichamen onder de microscoop de aanwezigheid van dergelijke stoffen zichrbaar maken. Enkele antilichamen die we op die manier hebben verkregen worden in her kort beschreven.

Het doel van het onderzoek dat in hoofdstuk 3 beschreven wordr, was een antilichaam te ontwikkelen dat ongedifferentieerde cryptcellen herkent. Men neemt namelijk aan, dat in een kankergezwel deze ongedifferenticerde cellen verantwoordelijk zijn woor de groei van de tumor. Dit hoofdsruk beschrijft de kenmerken van zo' $n$ antilichaam (5E9). 5 E9 bleck cen suikergroep te herkennen, die nier alleen op darmcellen voorkomt, maar ook op cellen van andere weefsels. We hebben een groot aantal kwaadaardige dikkedarmgerwellen onderzocht. De resultaten lijken erop te wijzen, dat $5 \mathrm{E} 9$ aankleuring geeft van gezwellen van patiënten met een korrere levensverwachting. Cadberime is cen molecule dat zorgt voor de verbinding tussen cellen. In kweken van kwaadardige cellen is aangetoond dar cadherine voorkomt dat kankercellen zich verspreiden. Om erachter te komen of cadherine het onderscheid maakt 
russen wel en net utzaiende cellen, hebben we in hoofdstuk 4 de anwexigheid van cadherine onderzoche in mormal sljmwlies. goed-en kwadaardige gezwellen van de dikke darm. In normal slijmwlies hebben we cadherine door middel wan kleuring angetoond, gelijkmatig verdeeld langs de wanden warmec cellen an elkar grenzen. In goed-en kwadaardige gezwellen was de aankleuring gelijk, maar zwakker. Het aankleuringparroon leek minder duidelijk, naarmate het gewwel minder onwwikkeld was. In sommige gexwellen bleek cadherine voor te komen langs die celwand die geen contact makt met butrcellen. Andere cellen toonden helemaal geen cadherinc-aankleuring. In hoofdsuk 5 beschrijf ik cadherine-ankleuring in wizaaingen wan dikke-darmgezwellen. Al die tumoren toonden eenzelfde aankleuring als die gevonden werd in de oorspronkelijke kanker, hoewel er binnen de tumor gebieden waren die meer of minder sterk aankleurden. Een verklaring hiervoor zou kunnen zijn dat in kankercellen die zich verspreiden en voor uitzaaingen zorgen, cadherine niet definitief, mat tijdelijk wordt onderdrukr. De resultaten van beide onderzoeken zoals beschrewen in de hoofdsukken 4 en 5 suggereren dat cadherinemoleculen vroeg in de ontwikkeling van dikke-darmkanker in aantal afnemen of verdwijnen. Daanaast lijkt de aanwezigheid van cadherine niet samen te hangen met een neiging tor uitwaien. Eerdere studies aan laboratorium-modellen hebben aangetoond dackankercellen gaan witzaaien als ze minder cadherine bevatten. De situatie in het menselijk lichaam blijkt echter ingewikkelder. We hebben immers gezien dat cadherine in verschillende kankersoorten, waaronder kanker van de dikke darm, anwezig blijfi ondanks een neiging tot uitzaaien. Dir verlies van celbinding zou te maken kunnen hebben met een verstoord adherine-catenine complex. Catenines verzorgen de verbinding tussen de adharines en her inwendige van de cel. Men heeft aangeroond dat de cadherines hun rol in de celbinding alleen in combinarie mer deze catenines kumnen spelen.

In hoofdstuk 6 hobben wij de arawezigheid van $\alpha$-en $\beta$-catenine in combinatic met cadherine onderzocht in goed-en kwadaardige dikke-darmgezwelten en hun uirzaaingen. In normal slijmwlies van de dikke darm werd catenine na ankletren op dezelfde plats zichtbar als cadherine. Ditzelfde beeld werd getien in alle goedardige en in de meeste kwaadardige gezwellen. We conduderen dat in het algemeen de kankercellen een overeenkomstige aankleuring van cadherine en catenine vertonen. Dit wijst erop, dat uitzaaing van kanker van de dikke darm niet vergezeld gaat van een blijvend verlies van catherines of carenines. 


\section{Nawoord}

Het proefschrift af op het nawoord ma en dar vind ik niet de simpelste opgave. In de afgelopen jaren hebben zóvele mensen cen min of meer subscantiële bijdrage geleverd en een meer of minder belangrijke rol gespeeld, dar er mij bij het rerugdenken steeds meer namen re binnen schieten die een ondoenlijk lange lijst opleveren. Het liefst zou ik ook diegenen mer wie ik zo af en toe eens gezellig op de gang kon klersen noemen in dic nawoord, want deze contacten bepaalden de werksfeer en dus her werkgenot, maar daar ben ik maar nier aan begonnen. Daarom in grote lijnen en in chronologische volgorde zo 'n zeven jaren "Maastricht".

De start was een onderzoeksplaars in her Biomedisch Centrum op her lab met Winand Dinjens, Edith van der Linden, Annick Haespoets en Marie-Heleme Lenders. Een betere start had ik mij niet kunnen wensen!! Het nier-aflatende enthousiasme en de inspiratie van met name Winand Dinjems, Joop ten Kate en Fré Bosman dienen mij nog steeds als voorbeeld.

Dr. Dinjens, beste Winand, jouw probleemoplossend vermogen,

frustrarie-tolerantie (hoeveel fusies en testen hebben we wel nier gedaan?) zijn fenomenaal! Ik heb enorm veel van jou geleerd. Dank je wel!

Dr. Ten Kate, beste Joop, mijn co-promotor, jii was er altijd, ook rijdens jouw opleiding tor klinisch-chemicus en erna. Hartelijk dank voor jouw steun en de gezelligheid bij jou thuis.

Prof. dr. Bosman, beste Fré, ik verlier de werkbesprekingen mer jou altijd enthousiast. Toen ik eenmaal AGlO was, verliep de communicarie - puur om geografische redenen -minder direcu, maar niet minder inspirerend. Hartelijk dank voor de open discussies en de alrijd snelle correctie van mijn teksten. De namen uir die begintijd wil ik toch tenninste exen nocmen, vanwege de goede herinneringen. Bij de pathologie: Ton de Goüj, Parter Moerkerk, Car Beck, Johan de Vries, Ellen wan Kleef, Monique Unmelen, Monidgue Verlayten, Jacques Cleutjens, Bert Schutte, Roel Kuijer, Patrick Marx, en Jobn Paulissen. Voorts Patul Bomans, Marc Stuart, Jos Belien en Peter Frederik van de EM, Wil Debie en Mieke Henfling (Immunologie). Tenslotte het secretariat: Ctaire Bollen en Marian Laarmans en een grote stroom studenten: Paulien Sibilderman, Daphone Pannemans, Josien Derhadg, Robert Passier en Sylwa Jans, Heno Mulder, Hollen Steinbusch en Marjolein van Driel. 
Na de verhuizing naar de nieuwbouw en het Academisch Ziekenhuis kwam ik in opleiding ro patholoog. De afstand tussen "research" en diagnostiek was geminimaliseerd, en zec plezierige bikomstigheid.

Prof. dr. Arends, beste Jan-Wiltem, na her vertrek van Fré en Winand werd jij als "mede-promotor" bij het onderzoek betrokken. Dank voor jouw constructieve inbreng, mer name rijdens de laatste jaren van mijn opleiding en voor de alajd zeer snelle correctie van mijn teksten.

Celbiologische kennis op geringe afstand had natast gezelligheid ook praktische waarde. Met name Gent Schatrt en Helma Kuypers hebben mij met antisera en blottingprocedures ter zijde gescaan.

Prof dr. Ramaters, beste Frans, we hebben kleuringen met diverse cytokerarines op diverse panels darmweefsel getest, maar tot een artikel is dit nooit gekomen. Dank voor jouw warme belangstelling en dank je wel dat je voorziter van de beoordelingscommissie hebt willen zijn. Op deze plats ook een woord van dank aan de overige leden van de commissie: prof. dr. Hillen, prof. dr. Mared, prof. di. Von Mcyerfeldt en prof. dr. Ruiter, voor her lezen van her manuscript. De opleidingstijd van 1991 tor 1996 was zeer gevarieerd. Met name door een hoog gezelligheidsgehalte op het lab (histologic, cytologie en de uitsnijruimte), de obductickamer en her secretariaat heb ik me altijd "thuis" gevoeld. Dank ook aan alle pathologen. Hoewel her soms moeilijk was jullie te pakken te krijgen, waren de vele uren die ik met jullie achter de microscoop heb doorgebracht zeker (en natuurlijk) leerzaam.

De arts-assistented bleken maatjes, met name de kamergenoten Prapto Sastrowyoto, Marti Kuizinga ("Heb je nog wat lekkers?"), Leo de Bruijckere en kort, maar nier minder gezellig Inez-Anne Haagen.

Heerlijk was de stageperiode te Tilburg en des te groter de vreugde dat ik mij per 1 februari patholoog mocht noemen met een baan in ther St.

Fisaberhxiekenhuis! Beste maten, volgens mij hebben we een fantastisch ream! ledereen van het lab, of het nu speciële, algemene of cytologie is, van her secretariaat, de obductieruime en het mortuarium, mede door jullie kom ik elle dag mer pleaier binnenstappen!

Lieve Edity en Margriet, jullie zijn nier voor niers mijn paranimfen. Ik ben blij dat jullic het ook leuk vinden om mij in deze hoedanigheid bij de promotie te steunen.

Last but nor least, naruurlijk Jan. Tim en Saar, maar ook Pa en Ma, Koos en Jenny, Haw, Olga en Alexandra, Jantje en Esther, Marjan, Frank, Ellen en Job, Andre en Jaap, ik houd van jullie!

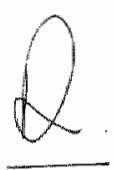




\section{Curriculum vitae}

Anna Adriana Maria van der Wurff werd geboren op 10 maart 1961 in Baarn. In 1979 behaalde zij her eindexamen WWO an het Baarnsch Lyceum. Gedurende het volgende jaar volgde zij een avondcursus bij de Stichting Aanvullend Onderwijs te Urrecht, waarna zij het Staatsexamen natuurkunde, scheikunde en biologie mer goed gevolg aflegde en in september $1980 \mathrm{kon}$ starten met de studie geneeskunde aan de Universiteir van Amsterdam. In 1986 behaalde zij her doctoraalexamen, waarna zij de co-schappen doorliep en uiteindelijk in augustus 1988 het artsexamen behaalde.

In oktober 1988 trad zij in dienst als Assistent-in-opleiding (A.O) aan de Rijksuniversiteit Limburg bij de vakgroep pathologie (prof. dr. F.T. Bosman). In de periode 1991 - 1996 doorliep zij de opleiding tot parholoog (opleider: prof. dr. J-W. Arends). In deze periode was zij van van januari 1993 tor en mer november 1994 gedetacheerd in het St. Elisabethziekenhuis in Tilburg (opleider: drs. J.F.M.M. Miseré), waar zij na het voltooien van haar opleiding sinds 1 februari 1996 werkzaam is als klinisch patholoog in een maatschap met drs. J.F.M.M. Miseré, drs. F.H.P.M. van Erren, dr. J.L.J.M. Teepen en dr. C.E.M. Blomjous. Het laboratorium voor parhologie verricht werkzaamheden ten behoeve van het Elisabethziekenhuis, het Tweestedenziekenhuis (vestiging Tilburg en Waalwijk), het Pasteurziekenhuis te Oosterhour, her Bernard Verbeeteninstituut te Tilburg en de huisartsen in de regio Centraal Brabant. $\mathrm{Zij}$ is getrouwd met Jan Hadders, neerlandicus en docent aan het Onze-LieveVrouwelyceum te Breda, en is moeder van Tim en Saar. 



\section{List of publications}

Wurff AAM van der, Kate J ten, Dinjens WWM, Linden EPM wan der, Arends JW. Bosman FT.

L-CAM expression in normal, premalignant and malignant colon mucosa.

Journal of Pathology 1992; 168: 287-291.

Bosman FT, Brume A de, Flohil C. Wurf AAM wan der, Kate J ten, Dinjens WNM. Epithelial-stromal interactions in colon cancer.

international Lournal of Developmental Biology 1993; 37: 203-211

Jacobs IA, Hendriks J), Verschure PD. Wurff AAM van der Freling $G$, VOS GD. Stobberingh EE.

Meningitis due to Fusobacterium necrophorum subspecies necrophorum.

infection 1993:21:57-60

Oranje WA, Pol P van. Wurff A van der, Zeijen RNM, Stockbrugger RW, Arends IW

XTC-induced hepatitis. Brief report.

Netherlands Journal of Medicine 1994:44:56-59

Wurff AAM van der, Arends IW, Linden EPM wan der, Kate J ten, Bosman FT. L-CAM expression in lymph node and liver metastases of colorectal carcinomas. Journal of Pathology 1994;172:177-182.

Schilderman PAEL, Vaanwerk FJ ten, Lutgerink IT, Wurff AAM wan der, Hoor F ten. Kleinjans $K 5$.

Induction of oxydative DNA damage and early lesions in rat gastro-intestinal epithelium in relation to prostaglandin H synthase-mediated metabolism of butylated Hydroxyanisole.

Food and Chemicall Toxicology 1995; 33: 99-109.

Tytgat KMAJ, Klomp LWJ. Bovelander F-J, Opdam FJM, Wurff AAM van der. Enemand AWC, Buler HA, Strous GJ, Dekker I.

Preparation of anti-mucin polypeptide antisera to study mucin biosynthesis.

Analytical Biochemistry 1995;226:331-341

Kasteren MEE van. Wurf AAM van der, Dolman A, Miseré JFMM.

Epitheloid hemangioendothelioma of the lung: cinical and pathological piltalls.

European Respiratory Journal 1995;8:1616-1619. 
Wurf AAM van der, Vermeulen 5I, Linden EPM van der, Bosman FT, Arends $M$. Patterns of $a$-and $B$-catenin and E-cadherin expression in colorectal adenomas and carcinomas.

Journal of Pathology $1997,182: 325-330$.

Wurff AAM van der Kate J ten, Marx PTJ, Linden EPM van der, Beek CCL, Bovelander F-J, Dekker J, Dinjens WNM, Mejenfeldt MF von, Arends IW, Bosman F. Expression of a marker for colonic crypt base cells is correlated with poor prognosis in human colorectal cancer.

Gut $1998: 42: 63 \cdots$

\section{Abstracts/proceedings}

Wurff AAM van der, Dinjens WMM, Kate J ten, Passier RPCJj, Jans SWS, Bosman FT.

Induction of Paneth cell differentiation in HT-29 cells

European Journal of Cell Biology 1990; 53 , suppl: 34.

Wurff AAM van der, Dinjens WNM. Kate J ten, De Bruine A, Bosman FT. A monodonal antibody specific for Paneth and neuroendocrine cells in the human intestine.

Cell Biology International Reports 1990; 14, suppl: 251.

Wurff A,AM van der, Kate / ten, Dinjens WNM, Linden EPM wan der, Arends MW, Bosman FT.

L-CAM expression in normal, premalignant and malignant colonic mucosa.

Proceedings of the 33rd Dutch Federation meeting 1992: 117.

Wurf AAM wan der, Kate I ten, Dinjens WNM, Linden EPM van der, Arends WW, Bosman FT.

Invasion and adhesion in colonic neoplasms.

The Histochemical Joumal 1992; $24: 566$.

Wurf AAM wan der, Kate J ten, Dinjens WMM, Linden EPM wan der, Arends JW. Bosman FT.

L-CAM expressie in normaal, premaligne en maligne colonslimmlies

Nederlands Tijdschrift voor Geneeskunde 1992; $136: 1688$

Wurf AAM van der. Arends MW Linden EPM van der, Kate J ten, Bosman FT. L.CAM expression in metastases of colorectal cancer.

Pathology Research and Practice 1993; 189: 835.

Wuiff AAM van der, Steinbusch HPJ, velde GPM ten, Thumnissen FBM. Basal cell component in non-small lung carcinoma.

The European Respiratory Joumal 1993; $6: 5345$ 
Thunnissen FBM. Velde GPM ten. Wurf AAM van der, Steinbusch HP, Wouters EFM, Wagenaar SjSC.

is the basal cell the stem cell in squamous cell lung carcinoma?

American Journall of Respiratory and Critical Care Medicine 1994; 4: A 179

Wurff AAM van der, Linden EPM wan der Kate $\mathrm{J}$ ten. Arena's IW. Bosman FT.

L-CAM expressie in colorectale tumoren en hun metastasen.

Nederlands Tijdschrift voor Geneeskunde 1994:40:2026.

Wurf AAM van der, Arends NW, Linden EPM wan der, Kate I ten, Bosman FT. Do metastases of colorectal cancer express L-CAMI?

Tumor Biology 1995; 16:118-119.

Wurff A.AM van der, Vermeulen SIT, Linden EPM van der, Mareel MM. Bosman FT. Arends jw.

Patterns of $\alpha$-and $\beta$-catenin and E-cadherin expression in colorectal adenomas and carcinomas.

(172nd Meeting of the Pathological Society of Great Britain and Ireland. Abstract 71. Londen, January 1996)

Peters HM, Mathijssen V. Wurff AAM van der, Manni J. Ruiter DJ.

Relation of E-cadherin and P-cadherin expression in head and neck squamouis cell carcinoma to patient prognosis

Pathology Research and Practice 1997;193/5-6:336. 